\title{
Approved genetically modified (GM) horticultural plants: A 25-year perspective
}

\author{
Rafal Baranski*, Magdalena Klimek-Chodacka, Aneta Lukasiewicz \\ Institute of Plant Biology and Biotechnology \\ Faculty of Biotechnology and Horticulture, University of Agriculture in Krakow \\ 29 Listopada 54, 31-425 Krakow, Poland
}

\begin{abstract}
In this review, we present genetically modified (GM) horticultural events that have passed the regulatory process and have been approved for cultivation or food use in different countries. The first authorization or deregulation of a GM horticultural plant issued 25 years ago initiated a fast expansion of GM organisms (GMO) engineered by using gene transfer technology. The list of GM horticultural species comprises representatives of vegetables, fruit plants and ornamentals. We describe their unique characteristics, often not achievable by conventional breeding, and how they were developed, and the approval process. Information on the adoption of GM horticultural cultivars and sale is accessed if commercialization has occurred. The review comprises, among others, Flavr Savr ${ }^{\mathrm{TM}}$ and other tomato cultivars with delayed ripening and improved shelf-life, insectresistant eggplant (or brinjal), as well as virus-resistant squash, melon and the common bean, and also fruit trees, plum and papaya. Cultivation of the latter was particularly valuable to farmers in Hawaii as it ensured restoration of papaya production devastated earlier by the Papaya ringspot virus (PRSV). In contrast, a plum resistant to sharka (Plum pox virus; PPV) deregulated in the USA is still awaiting commercialization. GM events with improved quality include the recently marketed non-browning apple and high-lycopene pineapple. We also present orange petunia, blue 'Applause' rose and Moon-series carnations with a modified purple and violet flower colour. Finally, we discuss prospects of GM horticultural plants, including their development using promising new breeding technologies relying on genome editing and considered as an alternative to the transgenic approach.
\end{abstract}

Keywords: Agrobacterium, authorization, commercialization, deregulation, genetic engineering, gene silencing, GM plant production, regulatory process, transgenic crops

\section{INTRODUCTION}

The first-ever commercialized genetically modified (GM) product was a horticultural crop plant, the Flavr Savr ${ }^{\mathrm{TM}}$ tomato, that appeared on the US market in 1994. This child of gene transfer technology has initiated continuous expansion of GM crop production in some countries, mainly in the Americas. The fast adoption of GM varieties has resulted in almost complete replacement in some countries of conventional varieties obtained in breeding crossing programmes of selected highvalue crops such as soybean, cotton, maize or sugar beet. Over the past $20+$ years, the total land area with GM plant cultivation has reached 185 million ha in the world, but horticultural GM crops have only a minor and often local contribution (ISAAA, 2016a). In this review, we discuss the past and

*Corresponding author. 
current GM horticultural plants that have been approved for cultivation or as food in at least one country to summarize the current status, show trends and prospects for their adoption. Approval decision for GM plant release to the environment or use is not equivalent to commercialization, thus some of the described GM events have passed the regulatory procedures successfully, but have never been released for commerce. We list GM horticultural plants retrieved from available databases, which provide updated information regarding the presence of genetically modified organisms (GMOs) worldwide, and describe the history of their development, characteristics, approval process and significance in horticultural production, if applicable.

\section{Sources of information on approved GM plants}

The most comprehensive reports on GM crop adoption into agriculture come from a nongovernmental organization, the International Service for the Acquisition of Agri-biotech Applications (ISAAA). This organization is supported by the United States Department of Agriculture (USDA) and the US Agency for International Development (USAID), national and non-governmental organizations as well as biotech companies (ISAAA, 2017). Some data in ISAAA reports have been occasionally criticized as overestimated (ACBIO, 2013); nevertheless, up-to-date ISAAA reports remain the main and complex sources of statistics related to biotech crops worldwide that complement the information released by governmental agencies. Approved GM events are also registered in national and international databases including those managed by the Biosafety Clearing House (BCH; http://bch. cbd.int/database), the European GMO Initiative for a Unified Database System (EUgenis; http://www. euginius.eu/euginius), the Center for Environmental Risk Assessment (CERA; http://cera-gmc.org/ GM\%20Crop\%20Database, not active now), while GM food is also listed by the FAO (Food and Agriculture Organization of the United Nations) GM Foods Platform (www.fao.org/gm-platform). We had retrieved information from all of them effectively by the end of 2017, taking into account inconsistencies occurring between database records, which have recently been depicted in a matrix comparison (Mallah et al., 2017). The CERA database has also been set off-line recently due to funding constraints, making information unavailable at the time of submission of this paper for publication.
The most complete and detailed information on the development methods and characteristics of individual GM events are included in dossiers gathered by regulatory agencies issuing approval decisions and in patent documentations. We, therefore, primarily provide relevant information retrieved from the original documents submitted by the developers that are made available to the public by national agencies. In the following subsections dedicated to individual GM plants, the majority of information comes from these original sources. However, some old submissions have been archived, and also not all agencies apply a transparency policy, making public information incomplete. Information collected from published papers, reports of independent institutions and agencies, and press announcements that were available at the time of approval or later has complemented and updated the original sources. The available data on GM crop cultivation may remain inaccurate, as regulations concerning the cultivation differ among countries, with many countries having no enforced regulations. Moreover, the largest producers require neither registration of cultivated GM crops nor obligatory labelling, thus information is limited or may not be released to the public by private companies, and press communications are usually disseminated without independent reviews.

\section{Regulatory processes}

GM plants developed using modern biotechnology were approved 25 years ago and then placed on the market. Their deliberate release into the environment for production and subsequent use for human food or livestock feed, or for other purposes, requires action to ensure they are safe for humans, animals and the environment. Different countries have adopted their own definitions of GMOs and GM products that have included diverse rules to be fulfilled before GMOs and GM products are commercialized in a given country. In some countries, GMOs are banned or not allowed for cultivation, while in other countries these issues remain unregulated by national laws (USDA, 2015a). The differences in laws imply different procedures whose outcome is not respected by other countries except within the EU, although EU member states have recently been given much independence in making decisions on GM plant cultivation regardless of the EU authorization (Directive (EU) 2015/412). The various procedures also imply that the same GM plant is evaluated using different measures, and the time necessary for 
issuing the final decision by regulatory agencies may considerably differ among countries. For example, the mean time of completing the regulatory process in the $\mathrm{EU}$ is about $50 \%$ longer than in the USA and takes, on average, 33 and 23 months, respectively (Smart et al., 2017). To ensure the transfer of corresponding information between countries, the Working Group on Harmonization of Regulatory Oversight in Biotechnology of the Organization for Economic Co-operation and Development (OECD) has developed guidance for a unique identifier (UID) for transgenic plants. The OECD UID is a nine-digit code assigned to every new transgenic event intended for commercialization, including plant cultivation and food and feed use, and allowing access to information in OECD databases and interoperable systems such as the Biosafety Clearing-House of the Convention on Biological Diversity (OECD, 2002). OECD UIDs are now commonly implemented by national agencies to avoid confusion in sharing information between agencies and countries using different regulatory procedures, and UIDs should accompany the GM event names that are commonly used in dossiers and research papers.

Laws and regulations dedicated to GMOs and their products have been discussed elsewhere (Wong and Chan, 2016; Smart et al., 2017). Comprehensive information on restrictions on GMO use in selected countries can also be found in the US Library of Congress at https://www.loc.gov/ law/help/restrictions-on-gmos. Only 10 countries currently cultivate GM horticultural crops (Fig. 1), but such crops have been approved for commercial cultivation or import in 13 countries, thus a brief overview of regulations is listed below, starting with three countries which are the most open to the adoption of biotech crops and which are not parties to the Cartagena Biosafety Protocol.

In the USA, the Animal and Plant Health Inspection Service (APHIS) of the United States Department of Agriculture (USDA) determines a non-regulated status of a GM event when it is unlikely to pose a plant pest risk after a comprehensive field and laboratory evaluation. Non-regulated GM plants can be cultivated and marketed in the same way as non-GM plants without any need for additional labelling. However, their use as human food or animal feed may also be a subject of voluntary evaluation by the Food and Drug Administration (FDA), which determines whether a GM plant or its product raises any safety or regulatory issues with respect to the intended modification or with respect to its use. All nonregulated horticultural GM events have been consulted by FDA so far. Additional restrictions apply to GM plants that produce a new substance and DNA in the plant when it is pesticidal in nature. Such plant-incorporated pesticides (PIPs), such as proteins conferring GM plant resistance to pests (e.g., virus coat protein), have to be registered by the Environmental Protection Agency (EPA) after risk assessment (see more at https://www.aphis.usda. gov/aphis/ourfocus/biotechnology/sa_regulations/ ct_agency_framework_role).

Brazil is the second largest country in the world allowing cultivation of GM crops. The Biosafety Law was enacted in 2005 and all issues related to GMOs and their products are subject to consideration by the National Technical Commission (CTNBio). In the case of GM plant evaluation, field trials are additionally supervised by the Ministry of Agriculture. Commercialized products must be labelled, but in recent years several companies have failed to label their products, which has restricted imports of GMO products (see more at http://www. loc.gov/law/help/restrictions-on-gmos/brazil.php).

Canada has implemented regulations that determine the approval procedure irrespective of the method used for plant development. Thus, whether recombinant DNA technology, mutagenesis or even conventional breeding is used, it is not a regulatory issue. However, if a GM plant food product has a distinguished new characteristic that has not existed on the market before, it must be evaluated as food with a novel trait and requires approval by Health Canada, which is responsible for human health-related issues. Health Canada cooperates with the Canadian Food Inspection Agency (CFIA) responsible for the evaluation of performance and environmental safety. A GM food product is considered as a novel food since it usually exhibits a novel characteristic due to the introduced DNA modification. Once approved, it does not require mandatory labelling nor monitoring (see more at https://www.canada.ca/en/health-canada/ services/science-research/reports-publications/ biotechnology/regulation-genetically-modifiedfoods.html).

Australia introduced the Gene Technology Act in 2000 and, accordingly, the Gene Technology Regulator is empowered to evaluate the risk of GM events to people and the environment. A GM event determined as safe is authorized by a GMO licence. When later determinations ensure that the licensed GM event poses a minimal risk, it can then be 


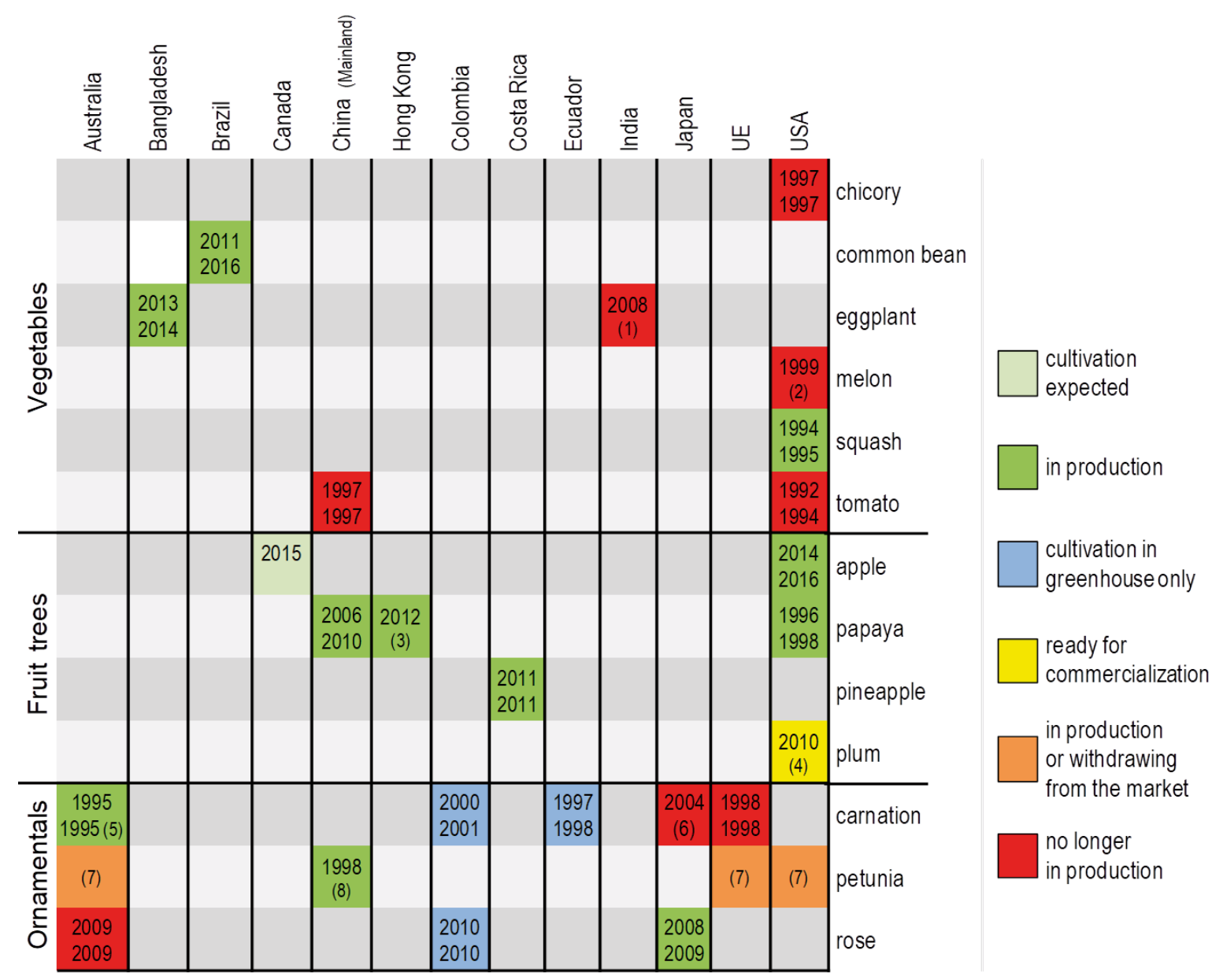

Figure 1. Current status of GM horticultural crop production in the world. Years indicate the year when the approval for cultivation was issued and the year of the first cultivation. Notes: (1) moratorium on the cultivation of GM eggplant has been maintained in India since 2010, (2) melon was approved as food in the USA, but not for cultivation, (3) GM papaya trees had been grown commonly in Hong Kong before a ban on GM crops was lifted in 2012, (4) cultivation in demonstration fields; trees have been ready for commercialization, if needed, for many years, (5) Australia allowed unlimited cultivation of selected carnation varieties in 2007, (6) Australia approved cultivation of GM carnation, but only imported flowers have been on sale, (7) it is suspected that GM petunia has been in production for many years, as such varieties were identified in several countries in 2017, (8) a limited production is most probably ongoing

included in the register of non-licensed GM events and used by anyone without further restrictions and concern for the health and safety of people or the environment (see more at https://www.agric.wa.gov. au/crops/grains/genetic-modification).

Cultivation of horticultural GM plants in other countries is much more restricted, not present or prohibited.

India is one of the top five countries cultivating GM crops. It has developed complex 'Rules for Manufacture, Use, Import, Export and Storage of Hazardous Microorganisms/Genetically Engineered Organisms or Cells 1989', with the Ministry of Environment and Forests coordinating other authorities involved in the GMO approval process, among them, the Genetic Engineering Appraisal Committee (GEAC), which issues approvals for GM crop cultivation and use. Although eggplant was the first and so far the only horticultural crop approved for cultivation, a moratorium on its production was imposed in 2010 that is still in force, thus no GM horticultural crops are grown at present.

China was the first country with commercial GM plant production initiated in 1994, although in the next years cultivation of GM varieties was restricted. At present, the cultivation, import, use and obligatory labelling of GM plants and products is controlled by the Ministry of Agriculture (MOA) and the GMO Biosafety Committee according to the national regulations enacted in 2001. GMOs and their products are allowed only when a GMO Safety Certificate is obtained; however, separate restrictive regulations, including bans, can be issued in each province. Separate regulations also exist in Hong 
Kong, but a GM papaya was exempted due to the fact that it had been widespread in that country. No other GM plant production is carried out in Hong Kong, but mandatory pre-market safety assessments and voluntary labelling were advised in 2017 by the Panel on Food Safety and Environmental Hygiene (PFSEH, 2017).

Bangladesh wishes to support gene technology, and thus the national regulations, Biosafety Guidelines of Bangladesh and Bangladesh Biosafety Rules, were developed in 2007 and 2012, respectively. It seems, however, that the regulations involve several national institutions supervised by different ministries and they do not cover all issues, in particular those related to import. Also, field trials are lacking clear guidelines for risk assessment. Nevertheless, cultivation of GM crops is allowed after receiving approval. Clear labels should also be placed on packages of GMOs or GM products, but the GM brinjal that is approved for cultivation is sold as fresh without packaging, thus farmers avoid the labelling requirement (GAIN, 2016a).

A stringent system is implemented in the $\mathbf{E U}$, where independent scientific and evidencebased evaluation of GM food and feed safety, and environmental risk assessment carried out by the European Food Safety Authority (EFSA) must then be authorized by politically dependent authorities, the European Commission and the Standing Committee on the Food Chain and Animal Health, or the Appeal Committee. Authorized GM plants and their products must be mandatorily labelled and monitored at every stage of cultivation and processing, and when placed on the market. These rules came into force ending a moratorium (19982004) on new GMO approvals. The decisions issued by member countries by 1998 remained valid for the next years and expired by 2008. In 2015, the EU Member States were given opportunity to decide whether to allow cultivation of the already authorized GM plants on their territory (Directive (EU) 2015/412), but this has not applied to horticultural crops yet, as only GM maize has so far been authorized for cultivation in the EU (see more at https://ec.europa.eu/food/plant/gmo_en). The consequences of the United Kingdom's withdrawal from the EU remain uncertain until a ratified withdrawal agreement is established.

Japan does not, in general, favour the cultivation of GM plants, except for GM rose, while imported GM plant products must be approved by a relevant ministry depending on the intended use of the product. Also, mandatory and voluntary labelling rules operate (USDA, 2015a) (see more at http:// www.mhlw.go.jp/english/topics/foodsafety/dna/01. html).

The prime role in the Colombian procedure for GM plant approval is played by the National Technical Committee for Agriculture, Fishery, Forestry and Agro-industry (CTN-Bio), which oversees the assessment of GM events during a long procedure involving the CTN for Environment, CTN for Health and Human Nutrition, and various ministries depending on the GM event's intended use. In 2015, the Constitutional Court ruled in favour of mandatory labelling, but the legislation has been not completed. Among cultivated crops, GM cut flowers have been approved for contained cultivation in greenhouses, but only for export (GAIN, 2016b).

The Costa Rican National Technical Biosafety Commission (NTBC) responsible for GMO-related issues was created in 1997, but after five years the national regulations on GMO were modified, making the approval process more politically dependent. Moreover, there are continued legal cases and actions by GMO opponents at local and national levels, resulting in an unclear status for GM plant cultivation and forcing biotech companies to move their activities out of the country (GAIN, 2016c).

Ecuador declares the country GMO-free, but in 2017 the National Assembly approved GM seed entry into the country for research purposes only. Nonetheless, greenhouse production of ornamentals for export of cut flowers has been allowed.

\section{GM crop production worldwide}

GM crops have become adopted into agriculture on a global scale. According to the recent ISAAA annual report, the total land area of all GM crops was 185.1 million ha in 2016 (ISAAA, 2016a). This is over $12 \%$ of the 1.5 billion ha of cropland worldwide. Beginning from 1996, when the first data on the cultivation of GM crops became available, the land use for biotechnologically improved cultivars has continuously increased, on average, by over 9 million ha annually, which corresponds to a yearto-year arable land increase of about $10 \%$ in 2000 -2012 and about $2 \%$ in the last four years. The recent slower adoption rate is partially related to the fact that the adoption of approved GM crops in the USA, the main biotech country, reaches its limits, as 90 $-100 \%$ of arable land used for soybean (94\%), maize $(92 \%)$, cotton (93\%), canola (90\%) and sugar beet $(100 \%)$ is already occupied by GM cultivars, with $47 \%$ of total arable land in that country taken by 
GM varieties. Thus, GM crops have been introduced en masse into the USA, which cultivates them on 72.9 million ha and dominates the world $(39 \%$ of the global GM cropland). The next four countries cultivating GM crops on more than 10 million ha are Brazil (49.1), Argentina (23.8), Canada (11.6) and India (10.8). The remaining 21 out of the 26 countries that have approved GM crops cultivate them on another 11.9 million ha, and the land area used varies among those countries from 3.6 million ha in Paraguay to only 75 ha in the Czech Republic. The latter still belongs to the shrinking group of EU members (four countries in 2016: Spain, Portugal, Slovakia, the Czech Republic) that allow GM crop cultivation on 0.136 million ha, with only Spain growing them on a large scale (0.129 million ha). The pronounced global adoption of GM crops contrasts with only a few GM plant species being cultivated on a large scale. GM soybean, maize, cotton, canola, alfalfa and sugar beet that are mainly herbicide and insect resistant are grown on 184.6 million ha. Thus, only 500,000 ha is used for other GM plant species, including horticultural species (ISAAA, 2016a).

The list of horticultural plants that have been genetically improved and allowed to be cultivated is short, but has grown recently with prospects for further expansion. Representatives belonging to all three main horticultural plant groups, i.e., ornamentals, vegetables and fruit trees, have been approved for cultivation in some countries since 1992 (Fig. 1). Three of them are of special significance. The Flavr Savr ${ }^{\mathrm{TM}}$ tomato was the firstever commercialized GM crop that opened markets for GM food, and a GM papaya (Carica papya L.) was used to replant orchards devastated by the Papaya ringspot virus (PRSV), which restored fruit production on the Hawaiian Islands. GM carnation is a non-food plant attracting with new flower colours and demonstrating the potential of GM technology for altering plant secondary metabolism.

\section{APPROVED GM HORTICULTURAL PLANTS}

\section{Vegetables}

\section{Tomato}

The first commercially available GM plant designed for human consumption was the Flavr Savr ${ }^{\mathrm{TM}}$ tomato (Solanum lycopersicum L.) developed by Calgene Inc. and introduced into the market in 1994. Tomatoes are soft fruit susceptible to damage, which affects harvesting practice. The fruit is harvested before ripening when it is hard and thus easier to handle during the distribution process. In consequence of harvesting before maturity, the fruit flavour can be less attractive. Therefore, the main aims of tomato modification focused on prolonging the period of fruit firmness or delaying softening, which would allow harvesting at a ripe stage, reduction of damage during transport and extended shelf-life. A few genetic engineering approaches were proposed to make tomato growing and distribution easier, including RNA interference (RNAi) of the polygalacturonase (PG) gene. The introduction of an additional copy of a gene of interest to the host cell may lead to a post-transcriptional gene silencing (PTGS) of this gene via interference with the endogenous mRNA. The major enzyme involved in pectin metabolism, which leads to fruit softening is PG (Hobson, 1965; Brady et al., 1982). It was assumed that PTGS of the PG gene would provide tomato with delayed fruit softening, thus meeting the farmers' and consumers' requirements. This concept led to the development of the Flavr Savr ${ }^{\mathrm{TM}}$ tomato (OECD UID: CGN-89564-2) by Calgene Inc. along with Da (OECD UID: SYN-000DA-9), F (OECD UID: SYN-0000F-1) and B (OECD UID: SYN-0000B-6) tomatoes developed by the British company Zeneca (Tab. 1).

The gene constructs used for the development of the Flavr Savr ${ }^{\mathrm{TM}}$ tomato by Agrobacterium-mediated plant transformation contained, as mentioned above, the tomato PG gene in antisense orientation under the control of CaMV $35 \mathrm{~S}$ promoter, $\mathrm{TmI}$ terminator and transcript 7 of the A. tumefaciens pTiA6 plasmid gene, accompanied by the nptII gene with mas promoter and terminator. The construct was inserted into one of the binary vectors pCGN1548, pCGN1549, pCGN1157, pCGN1158, pCGN1159, pCGN1578 (BCH, 2012a). The events Da, F and B were developed via Agrobacterium-mediated transformation of cotyledons excised from the T7 tomato line. The F and Da events were obtained after transformation using the PJR16S binary vector with the construct containing a partial PG gene in sense conformation, while the $\mathrm{B}$ event was developed using the PJR1A vector with a partial antisense PG sequence. In both constructs, the expression of the mentioned fragments was controlled by the CaMV 35S promoter and nos terminator and, additionally, the $n p t I I$ selection gene was used with nos promoter and terminator (BCH, 2013a, 2013b, 2013c). The transgenic plants were selected at first according to a PG level, then based on the number 


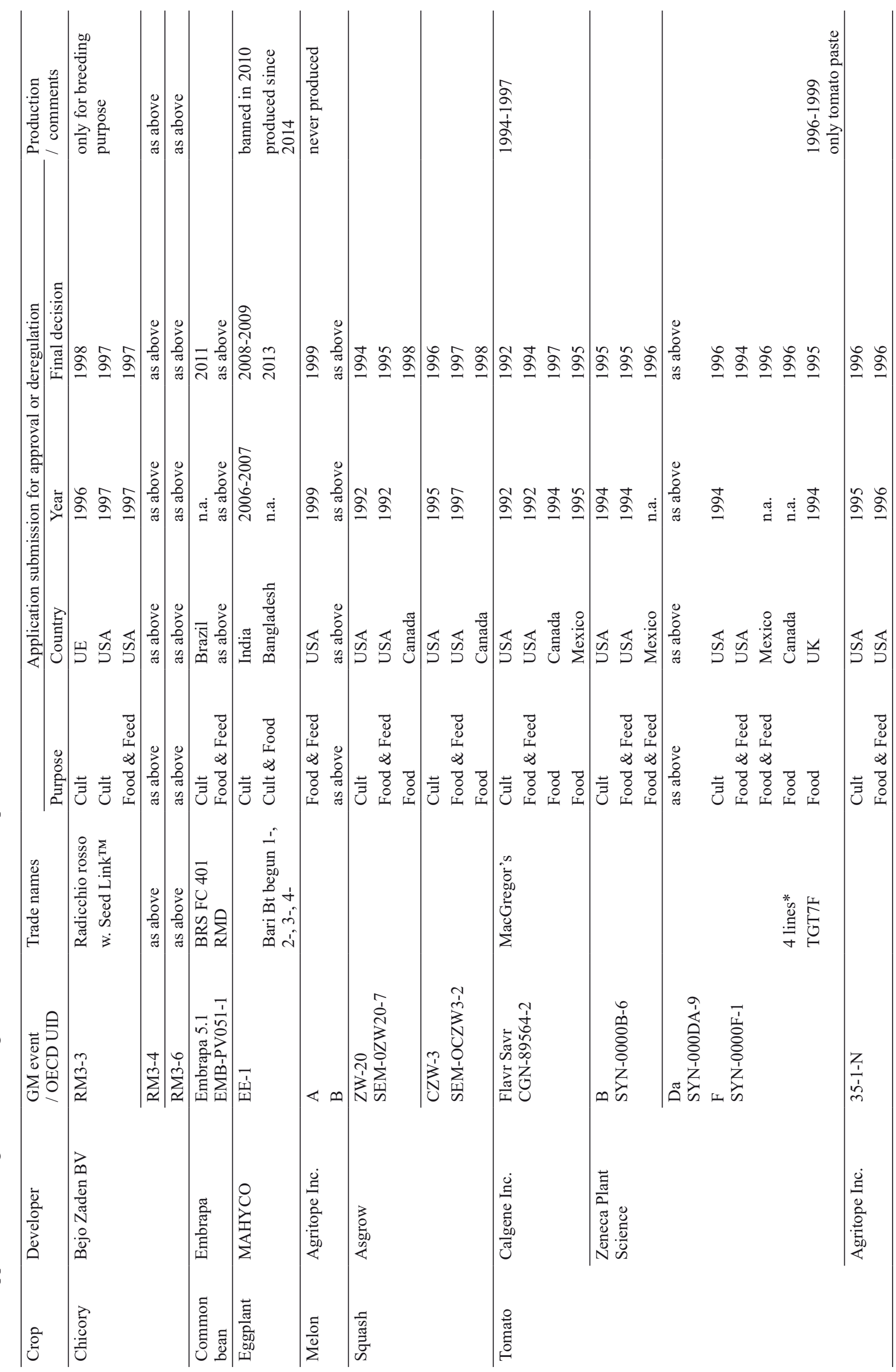




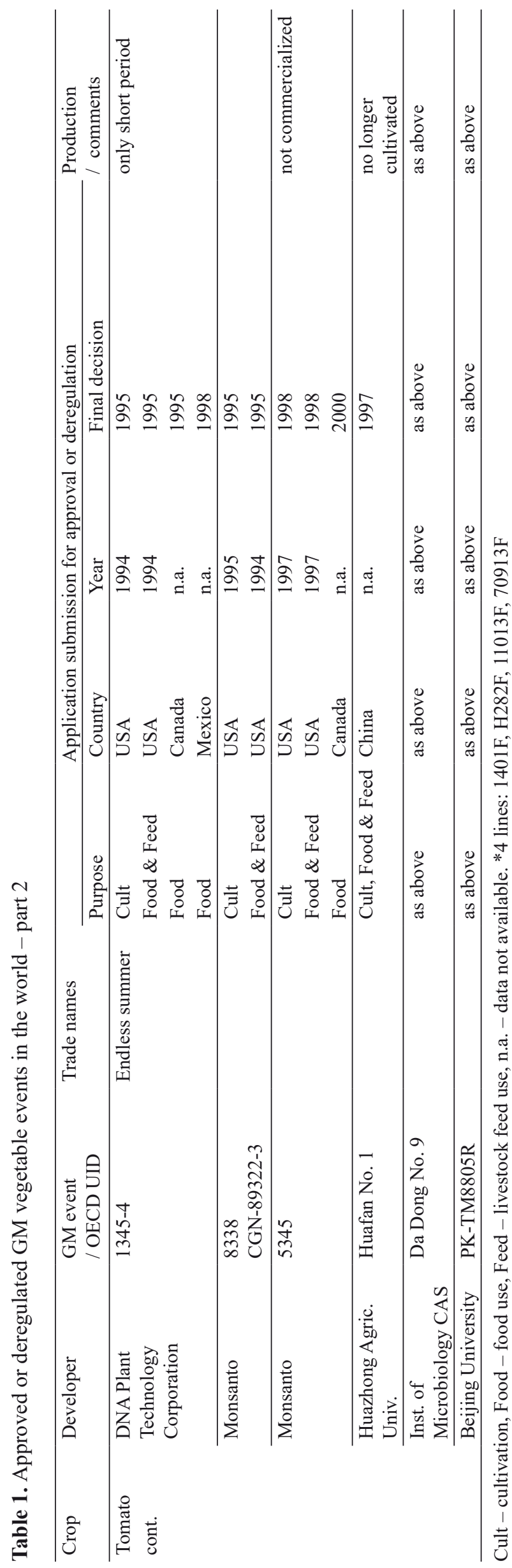

of insertions, and finally after field evaluation of agronomic traits. Ultimately, lines with a reduced PG level, single insertion and showing equivalent agronomic characteristics as the parental $\mathrm{T} 7$ line were selected. Homozygous B, Da and F inbred lines and hybrids derived from them were verified at a molecular level using PCR. The results showed that in the B and Da lines the complete insert was present, while in the $\mathrm{F}$ line a deletion occurred at the T-DNA right border region. It was concluded that the deletion was located between the right border and the nos terminator because the PCR analysis with primers flanking the $n p t I I$ region was positive (APHIS, 1994a).

The described genetic modifications increased the consistency and viscosity of the tomato fruit, and decreased fruit softening rate. The PG activity in the Flavr Savr ${ }^{\mathrm{TM}}$ tomato fruit decreased by $99 \%$. Also, a temporary delay in fungal infection was observed, most probably due to a longer fruit hardiness. No other unintentional effects were observed (APHIS, 1992a). The transgene was stably inserted, inherited through generations and segregated in accordance with the Mendelian fashion. Field trials of the transgenic inbred and hybrid lines derived from the B, Da and F events showed no substantial agronomic changes when compared to the non-GM control, and the introduced PG gene had no impact on other qualities besides the intended increase of fruit firmness (APHIS, 1994a).

Calgene started consultations with the FDA in 1989. At that time, regulatory procedures for evaluation and approval of food derived from genetically modified plants had not been established yet, so the Calgene case paved the way for the determination of regulatory status for other genetically modified crops. In response, the FDA published a new policy in 1992, stating that food from a genetically modified plant would be regulated under the same articles as any other food (FDA, 1992). Along with that, the FDA viewed the protein expressed from the marker gene as a food additive. Calgene submitted a petition to the FDA for determining Flavr Savr ${ }^{\mathrm{TM}}$ regulatory status and, as a part of that petition, for allowing the presence of NPTII protein in tomato fruit. The FDA issued an approval in 1994 (FDA, 1994) (Tab. 2). In 1992, the Flavr Savr ${ }^{\mathrm{TM}}$ tomato was deregulated by APHIS (APHIS, 1992b). Calgene submitted five other petitions to APHIS in 1994-1996 (APHIS, 1994b; APHIS, 1994c; APHIS, 1995a; APHIS, 1995b; APHIS, 1996a), and all of them were extensions of the original petition from 1992 for additional GM 


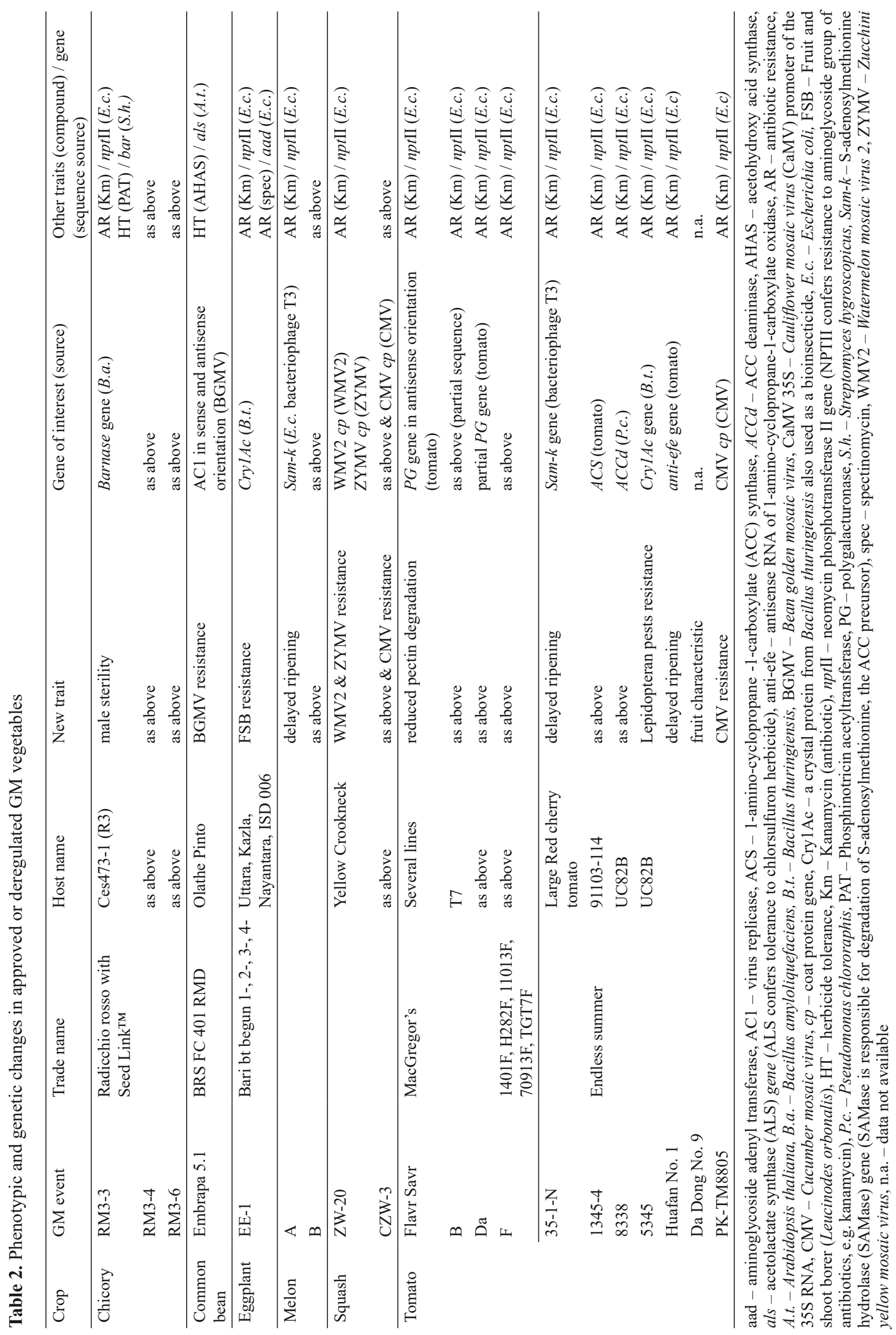


lines. The Flavr Savr ${ }^{\mathrm{TM}}$ tomato was also approved for direct use as a food in Mexico (COFEPRIS, 2018) and received positive assessments from Health Canada (HC, 1995a). Zeneca's Da, F and B tomato events underwent analogous procedures and they were deregulated by APHIS (APHIS, 1995c) and FDA (FDA, 1995a), and a year later they were approved in Mexico (COFEPRIS, 2018). Zeneca also received approval from Health Canada for food use of the hybrids 1401F, H282F, 11013F, 70913F derived from the transgenic $\mathrm{F}$ line (HC, 1996). A tomato paste from the fruit of two $\mathrm{F}$ tomato hybrids was also approved by the UK Advisory Committee on Novel Foods and Processes (ACNFP) in 1995. Meanwhile, the new EU regulation 258/97 was introduced and Zeneca requested safety evaluation from the UK authority, the EC Scientific Committee on Plants (SCP) and the Scientific Committee on Food (SCF), and in 1998 and 1999, respectively, received their final opinions stating that the GM tomatoes were substantially equivalent to conventional tomatoes (CERA, 1998; EC, 1999; IATP, 2001).

The Flavr SavrTM tomato (also known by its trade name MacGregor's tomato) was introduced into the market in the United States in 1994 and was clearly labelled. As a plant product made by using a new technology, it aroused consumer interest. However, the GM tomato was more expensive than a conventional one, and the fruit were less firm than expected, causing distribution problems. Also, the fruit taste was not appreciated because inappropriate varieties had been chosen as parental material. Hence, the Flavr Savr ${ }^{\mathrm{TM}}$ tomato was withdrawn from the market in 1997. In contrast, Zeneca's Da, $\mathrm{B}$ and $\mathrm{F}$ tomato lines were not designated for the fresh market, but for processing. Among them, the $\mathrm{F}$ line and hybrids derived from it had the highest commercial value. Although they were grown in the United States, Zeneca collaborated with the Safeway and Sainsbury's store chains in the United Kingdom, which sold 1.8 million cans of tomato paste from Zeneca's tomatoes. The product was labelled voluntarily. However, Safeway and Sainsbury's decided to withdraw it from sale in 1999 when the negative reception of food derived from genetically engineered plants had escalated (Bruening and Lyons, 2000; Elderige, 2003).

Other approved tomatoes were also modified to reduce fruit loss during fruit distribution. Events 35-1-N, 1345-4 and 8338 were developed for a delayed ripening phenotype. Tomato is a climacteric fruit, which means that the expression of genes involved in ripening is ethylene-dependent
(Yokotani et al., 2009). Thus, it had been assumed that modification in the ethylene biosynthesis pathway could provide fruit with better quality and extended shelf-life. This phenotype was achieved in the 35-1-N event by introducing the $s a m-k$ gene encoding S-adenosylmethionine hydrolase (SAMase) responsible for the degradation of S-adenosylmethionine (SAM). The latter compound is the precursor of 1-aminocyclopropane-1carboxylic acid (ACC), which is then converted to ethylene. Therefore, the degradation of SAM by SAMase inhibits ethylene biosynthesis. The 1345-4 event was developed by introducing a construct with the ACC synthase $(A C S)$ gene, which is responsible for the conversion of SAM to ACC. The expression of additional copies of the $A C S$ gene induced the above-mentioned mechanism of RNAi, leading to gene silencing. For the development of the 8338 event, the construct used contained ACC deaminase (ACCd), which is the enzyme responsible for the metabolism of ACC, thus its expression also resulted in the inhibition of ethylene biosynthesis (BCH, 2014a, 2014b, 2014c).

The 35-1-N event developed by Agritope Inc. had introduced a modified $s a m-k$ gene from bacteriophage T3 under the control of fruit-specific E8 promoter from tomato, and nos terminator with an additional $n p t \mathrm{II}$ selection gene with nos promoter and ocs terminator. The parental line of the 35-1-N event was a cherry tomato variety, called Large Red Cherry tomato, developed by Petoseed. The A. tumefaciens EHA101 strain with pAG 5420 vector was used for gene construct delivery. The initial identification of transformants was done by selecting seedlings on a kanamycin -enriched medium. Western blot analysis confirmed fruit-specific expression of the $s a m-k$ gene in the developed plants. Southern analysis was carried out to determine the number of transgene copies, their location and stability in the next progenies. The results indicated that T-DNA was integrated in one locus, in two copies, but one of them was incomplete. Southern blot assays of R3 and R5 progenies revealed that the transformation was stable through generations. Besides the integration of the T-DNA region into the tomato genome, nonfunctional fragments from a vector backbone were also identified. (APHIS, 1995d).

DNA Plant Technology Corporation generated the 1345-4 event via A. tumefaciens-mediated transformation of the tomato 91103-114 parental line using the pWTT2144/AccS vector. The introduced DNAs were 1) ACS gene fragment under the control 
of CaMV 35S promoter, Cab22L gene leader, and nos terminator, and 2) nptII with nos promoter and ocs terminator. The $A C S$ gene fragment was a truncated version $\left(-149 \mathrm{nt}\right.$ at $5^{\prime}$ and -220 at $3^{\prime}$ ends) of the $A C C 2$ gene from tomato, thus no functional enzyme was synthesized. The presence of the truncated $A C S$ suppressed the translation of endogenous ACC2 mRNA. The technology used to develop the 1345-4 tomato is called Transwitch ${ }^{\mathrm{TM}}$, and it was patented by the company (Bedbrook et al., 1997). There were three T-DNAs inverted repeats assembled in the 1345-4 genome, but one of the borders from each junction site (LB-LB, RB$\mathrm{RB})$ was removed. The T-DNA borders flanking the whole insertion region were also deleted. Further examination showed that the T-DNA remained intact in progeny, and no further rearrangements or deletions were observed (APHIS, 1994d).

The 8338 event was developed by Monsanto via Agrobacterium-mediated transformation of the UC82B tomato line. The delivered T-DNA region contained the $A C C d$ gene from Pseudomonas chlororaphis 6G5 strain with a modified Figwort mosaic virus $35 \mathrm{~S}$ promoter, HSP70 gene leader from Petunia $\times$ hybrida and rbc-E9 non-translated region as polyadenylation signal. Additionally, it possessed the nptII gene under the control of CaMV $35 \mathrm{~S}$ promoter and nos terminator. The construct was inserted into PV-LERP07 (pMON100117) vector. Southern blot analysis showed that the gene construct was inserted into plant genome in one copy with single $A C C d$ and $n p t I I$ genes. No vector backbone DNA was detected. The transgene stability was confirmed in backcross progenies derived with non-transgenic varieties for four generation (APHIS, 1995e).

Field evaluation showed that $35-1-\mathrm{N}$ plants had extended ripening time from breaker to fullred stage, which was an intended change. The production of ethylene was reduced in breaker to light-red fruit stage when compared to the non-transgenic control, but in fully mature fruit the expression of the $s a m-k$ gene was weakened (APHIS, 1995d). Field tests of 1345-4 plants were carried out in the United States in 1992-1994 and showed that there were no significant differences in agronomic characteristics between the transgenic line and control, besides the intended change in delayed ripening. In the control line, $29 \%$ to $44 \%$ of fruit was in the light-red or red-ripe stages, while in the transgenic line and its F1 hybrids less than $17 \%$ of fruit was in the light-red stage and none was in the red-ripe stage. However, two GM hybrids had a higher percentage of fruit at the redripe stage, which was explained by "differences in the penetrance of the delayed-ripening phenotype in different backgrounds" or "differences in the 'earliness' and 'lateness' of the other parent in the hybrids". Harvesting was done when at least $50 \%$ of the control fruit was in the breaker stage, then the difference in marketable fruit share was observed. $95 \%$ of the yield of the transgenic lines and GM hybrids was considered marketable, while in the control only 54-73\% (APHIS, 1994d). The general characteristics of the 8338 line were the same as those of the control line, but only on two out of four field sites the yield was equivalent to that of the control line. On the other two sites, the yield from GM plants was notably lower than in the control, which was attributed to the occurrence of Fusarium crown rot. The mean value of ACCd in red-ripe tomato fruit of the 8338 line was 39.4 $\mu \mathrm{g} \mathrm{g}^{-1}$ fresh weight, while the enzyme was not detected in the control (APHIS, 1995e). The GM fruit had a significantly reduced ethylene content and extended ripening time (Reed et al., 1995).

Monsanto's 8338 tomato was deregulated by the FDA (FDA, 1995b) and APHIS in 1995 (APHIS, 1995f). A year later, the same status was granted to the 35-1-N tomato (APHIS, 1996b; FDA, 1996). The 1345-4 line was approved for cultivation, as feed and for human consumption in the USA in 1995 (APHIS, 1995g; FDA, 1995c), and produced under the name 'Endless Summer' for a short time. It was also approved in Canada (HC, 1995b) and Mexico (COFEPRIS, 2018), but limited to imports for consumption and not for releasing into the environment.

An insect-resistant tomato event, designated 5345, was developed by Monsanto. The intended resistance to lepidopteran pests was obtained by expressing the CrylAc protein, which had been widely used as a bioinsecticide for the protection of conventional cultivars. Laboratory analyses showed that the introduction of the CrylAc gene was an efficient way to withstand several lepidopteran pests in tomato - the tomato fruitworm (Helicoverpa zea), pinworm (Keifera lycopersicella), hornworm (Manduca sexta), along with the potato tuber moth (Phthorimaea operculella) and cabbage looper (Trichoplusia ni). Tomato protection from pests by expressing the CrylAc protein was more efficient than foliar application of the insecticide and reduced the workload necessary to manage pests (Fischhoff et al., 1987; Dellanay et al., 1989; APHIS, 1997a). The 5345 tomato event was obtained by 
the A. tumefaciens-mediated transformation of the UC82B variety. A single border vector, PVLEBK04, contained the crylAc gene derived from Bacillus thuringiensis subsp. kurstaki with CaMV 35S promoter and 7S 3' untranslated region, which provided a polyadenylation signal, and the aad gene coding for aminoglycoside adenyl transferase with its own promoter and terminator. The nptII gene with the CaMV 35S promoter and nos terminator were also included in the T-DNA vector. A single insertion of the gene construct was found in the transgenic event and its stable integration was confirmed through seven generations. The expressions of the CrylAc and NPTII proteins were evaluated by an enzyme-linked immunosorbent assay (ELISA), and of the AAD protein by Western blot. The level of the CrylAc protein differed among plant organs. The highest level was detected in young leaves and the lowest in red-ripe fruit (a mean of $13.32 \mu \mathrm{g} \mathrm{g}^{-1} \mathrm{FW}$ and $0.70 \mu \mathrm{g} \mathrm{g}^{-1} \mathrm{FW}$, respectively). The aad gene was present in plant genome, but, since it was under the control of its own bacterial promoter, it was not expressed. The 5345 GM line was monitored in field trials conducted in the United States and in Puerto Rico, and no changes in growth or development were observed (APHIS, 1997a). The company submitted a petition to the USDA's APHIS in 1997, and a safety assessment to the FDA, and a year later the 5345 event was approved by both agencies (APHIS 1997b, FDA, 1998). It also received a positive opinion from Health Canada (HC, 2000). The transgenic line was not registered as a pesticide by the Environmental Protection Agency (EPA) and therefore has not been commercialized (ILSI, 2011).

Three other tomato GM events, Da Dong No. 9, Huafan No. 1 and PK-TM8805R, were developed in China, but not registered in the OECD UID database. Huafan No. 1 and Da Dong No. 9 had fruit quality altered, while PK-TM8805R was modified for virus resistance. Huafan No. 1 was developed by Huazhong Agriculture University after microparticle bombardment with a construct containing the anti-efe gene from tomato, coding for an antisense RNA of 1-amino-cyclopropane1-caboxylate oxidase (ACO) known as ethyleneforming enzyme (EFE), driven by the CaMV 35S promoter. Additionally, the nptII selection gene was introduced. RNAi mechanisms cause the silencing of the ACO gene, which results in a delayed-ripening phenotype (BCH, 2012c; Kitagawa et al., 2014). The PKTM8805R event from Beijing University exhibited resistance to the Tobacco mosaic virus (TMV) and Cucumber mosaic virus (CMV), which are the main viruses posing a threat in tomato cultivation in China. Although the TMV resistance in tomato had also been achieved by conventional breeding, the CMV resistance was introduced to tomato by applying genetic transformation only (Chen and Yang, 1996). The PKTM8805R event was obtained after Agrobacterium-mediated transformation with a construct containing the CMV coat protein under the control of the CaMV $35 \mathrm{~S}$ promoter and nos terminator, and the nptII gene (BiosafetyScanner, 2018). Da Dong No. 9 was developed by the Institute of Microbiology of the Chinese Academy of Sciences, but there is no information available about the introduced construct or the transformation method.

The Huafan No. 1 event was approved for cultivation, as food and feed by the Ministry of Agriculture in China in 1997, and Da Dong No. 9 and PK-TM8805R in 1999 (BCH, 2012c, 2012d, 2012e). The PK-TM8805R was cultivated in a few provinces of China - Fujian, Yunnan, and in Beijing Municipality. It is estimated that the largest area of GM tomato cultivation was in Fujian Province because $\mathrm{CMV}$ outbreaks had occurred in that region (Puette, 2016). There are no available records of cultivation of the above-mentioned tomatoes in China today.

\section{Eggplant}

The eggplant (Solanum melongena L.) fruit, also known as brinjal or aubergine, is an important food and income source in India, Bangladesh and the Philippines, especially to poorer farmers. The eggplant event EE-1 (Elite event 1) was India's first biotech food crop developed by Maharastra Hybrid Seeds Company (Mahyco) in cooperation with Cornell University and Monsanto (Tab. 1). This event was resistant to the eggplant fruit and shoot borer (FSB; Leucinodes orbonalis). FSB larvae boring into shoots, leaves, and petioles cause retardation of plant growth, wilting and flower shedding, thus lowering the number of fruit. They also feed inside the fruit, destroying the already developed fruit and making the crop unsuitable for marketing. The pest can cause $51-73 \%$ yield losses annually (ISAAA, 2016b). The use of pheromone traps and manual removal of insects is ineffective in pest control. When there are signs of FSB occurrence on farmland, farmers use pesticides but since FSB larvae bore into the plant interior, they are not exposed to chemical treatment and continue feeding and destroying crops, and, in consequence, farmers use more pesticides. This vicious circle has 
led to excessive usage of toxic chemicals that have a negative impact on the environment, on farmers' health and eventually on consumers' health. Since there are no eggplant genotypes with appropriate levels of resistance, the development of resistant cultivars through traditional breeding remains challenging and has stimulated development of GM pest-resistant eggplant by applying the same approach as has already been used in Bt cotton cultivated in India (Choudhary and Gaur, 2009).

The EE1 event was derived through A. tumefaciens-mediated transformation of cotyledons with a construct containing the crylAc gene from the Bacillus thuringiensis subsp. kurstaki HD73 strain, with the CaMV 35S promoter and $7 \mathrm{~S}$ alpha terminator from soybean, along with the nptII gene under the control of the CaMV promoter and nos terminator, and the aad gene, which was not expressed in the plant since it was controlled by the bacterial $\mathrm{Tn} 7$ promoter. The plants were regenerated and analyzed in the following generation by a Southern blot assay, which showed the same pattern of restricted fragments in progeny as in the original GM plant. The EE-1 line was backcrossed with common varieties of Indian eggplant. The Southern blot assay revealed that the transgene construct was inserted into one locus of the eggplant genome and that the insert was a single copy. The expression of the CrylAc protein was different in plant organs. Quantitative assessment based on an ELISA assay showed 5 to $47 \mathrm{ppm}$ of Cry1Ac in shoots and fruit, respectively.

The developed technology was shared for free with the University of Agricultural Sciences (UAS), Tamil Nadu Agricultural University (TNAU), the Indian Institute of Vegetable Research (IIVR) and also with research institutions in Bangladesh and the Philippines. Hybrids of EE-1 were tested in 2001-2009. The studies included the impact on other insects, field evaluation, feeding studies, and environmental impact and substantial equivalence studies. The bioassay showed that EE1 was highly resistant to FSB (98\% insect mortality in shoots and $100 \%$ in fruit, while in non-GM plants the mortality was less than $30 \%$ ), required $77 \%$ less insecticides to control the FSB, and $42 \%$ less other insecticides, which would give farmers estimated savings of 330 to 397 US\$ per acre (ISAAA, 2009; Biology discussion, 2016).

The EE1 line was approved for cultivation in India by the Genetic Engineering Approval Committee (GEAC) in 2009 (Tab. 2). In 2010, the Minister of Environment and Forests (MOEF), after negative public comments on genetically modified eggplant, announced a moratorium that still remains in force (MOEF, 2010). In the Philippines, the University of the Philippines Los Banos received permission for field trials of Bt eggplant from the Bureau of Plant Industries (BPI), but in 2013 the Court of Appeals (CA) stopped the field trials after receiving a petition from Masipag farmers' group and Greenpeace, and stated that "the field trials of genetically modified organisms Bt talong (eggplant - red.) could not be declared as safe to human health and to our ecology with full scientific certainty, being an alteration of an otherwise natural state of affairs in our ecology". In 2015, the Supreme Court in the Philippines upheld the decision of the CA. $\mathrm{A}$ year later, the decision was reversed and now $\mathrm{Bt}$ eggplant is a step closer towards commercialization in the Philippines (Rappler, 2016; Carillo, 2017) In 2013, after 5 years of field trials, four Bt eggplant varieties developed by the Bangladesh Agricultural Research Institute (BARI), by using the technology shared by Mahyco and applied to local varieties, were approved for commercialization in Bangladesh (Bakum, 2015). The production of Bt eggplant started in 2014 when the seedlings were distributed for free by the Minister of Agriculture Matia Chowdhury to selected farmers in four country regions. Bt eggplant was grown on 2 hectares and, in the next season, on 12 hectares, and on 25 hectares in 2015, and 700 hectares in 2016. The number of farmers also increased from 20 in 2014 to over 5000 in 2016 (ISAAA, 2016a). GAIN Report (2016a) estimates indicated that 23,000 farmers would cultivate brinjal on 4500 hectares in 2016. The government still remain in favour of $\mathrm{Bt}$ varieties and have planned to distribute free GM seeds and fertilizers among 2000 farmers from 64 districts (ISAAA, 2015; Siddique, 2017). The Bangladesh Agricultural Research Institute plans to release additional three varieties of Bt eggplant in the near future (SEARCA, 2017).

\section{Squash}

Two GM squash (Cucumis pepo (L.) ssp. ovifera var. ovifera (L.) Harz) events, ZW-20 (OECD UID: SEM-0ZW20-7) and CZW-3 (OECD UID: SEM0CZW3-2), were developed by Asgrow (Tab. 1). Both events were resistant to potyviruses, namely the Watermelon mosaic virus-2 (WMV2) and the Zucchini yellow mosaic virus (ZYMV). The CZW3 event was additionally resistant to a cucumovirus i.e., the Cucumber mosaic virus (CMV). All three viruses are RNA viruses occurring worldwide, 
with a wide range of hosts, and they are easily transmitted by aphids. The infected plants usually have a reduced leaf size, discoloured and deformed fruit, and stunted growth resulting in reduced yields (Lisa and Lecoq, 1984; Alonso-Prados et al., 1997; Luis-Artega et al., 1998).

The ZW-20 and CZW-3 events were derivatives of the cultivar 'Yellow Crookneck', obtained after Agrobacterium-mediated transformation of leaf discs. ZW-20 was transformed using the A208.35 A. tumefaciens strain with the ZYMV72/WMBN22 vector (Tricoli et al., 2002), a modified pPRBN vector. The T-DNA region contained coat protein (CP) genes from the WMV2 NY and ZYMV FL strains, and additionally the $n p t I I$ gene. Each gene was flanked by the CaMV $35 \mathrm{~S}$ promoters and terminators. To enhance translation, the ZYMV $c p$ gene was fused with the CMV $5^{\prime}$ untranslated region, and the WMV2 $c p$ gene was fused with the 5 ' untranslated and N-terminal regions of the CMV $c p$ gene. The original regenerated GM plant had five imperfect insertions of the T-DNA. Four inserts were truncated and did not contain $n p t \mathrm{II}$, one insert had no WMV2 $c p$, and one contained only ZYMV and $n p t \mathrm{II}$. In the following generation, Asgrow selected lines expressing WMV-2 and ZYMV only and lacking the $n p t I I$ gene.

Explants transformed with the CMV/ZYMV72/ WNBN22 vector, a modified ZYMV72/WMBN22, resulted in the development of the CZW-3 event. The T-DNA used contained $c p$ genes of WMV NY, ZYMV FL and CMV C strains, and the $n p t I I$ gene, all of them with the same CaMV $35 \mathrm{~S}$ promoters and terminators, analogously as in ZW20. The CZW -3 and ZW20 transgenic lines were evaluated in field tests in various locations in the United States. Plants were initially inoculated mechanically, with each virus individually, and then exposed to virus-transmitting aphids. CZW-3 plants showed no symptoms of CMV, WMV-2 and ZYMV, even under high pressure when plants were inoculated with all three viruses, and ZW20 plants were found resistant to ZYMV and CMV. No other changes were observed on the GM plants when compared to the non-GM control plants (APHIS, 1992c; APHIS, 1995h).

In 1992, Asgrow started consultations with the FDA and submitted a petition to APHIS for the determination of non-regulated status of ZW20, which was approved in 1994 (APHIS, 1995i) (Tab. 2). In the same year, the company submitted a summary of a nutritional and safety assessment to the FDA, and a year later they received an opinion that, since ZW-20 was not materially different from non-GM squash varieties present at the time on the market, it therefore no longer required any premarket reviews or FDA's approval (FDA, 1995d). The hybrid 'Freedom II' derived from ZW20 hit the market in 1995. A petition to deregulate CZW-3 was submitted to APHIS in 1995 (APHIS, 1995h) and approved by the agency the next year (APHIS, 1996c), and then also by the FDA (FDA, 1997a). Both lines were also regarded as safe for human consumption by Health Canada in 1998 (HC, 1998a, 1998b).

\section{Melon}

The ripening of the cantaloupe melon (Cucumis melo L.) fruit is fast and causes postharvest losses due to the production of over-ripened fruit, which additionally has a short shelf-life (Dahmani-Mardas et al., 2010). Two melon GM events, A and B, with delayed fruit ripening, were developed by Agritope Inc. (Tab. 1). These events were obtained using essentially the same approach as in the case of the tomato 35-1-N event with the introduced SAMase gene.

The A and B events were developed through Agrobacterium-mediated transformation with a construct containing the $s a m-k$ gene under the E8/E4 hybrid promoter and nos terminator control, and the $n p t I I$ gene with the raspberry RE4 promoter and gene 7 terminator from A. tumefaciens. The company used PCR analysis to demonstrate that only the T-DNA region was transferred into melon and remained intact in the plant genome, as well as Western blotting for quantitative and qualitative analyses of expressed proteins. Agritope showed that the $s a m-k$ gene is expressed temporarily only in mature fruit; no SAMase was detected in unripe fruit nor in other plant parts. The level of SAMase was $32 \mathrm{pg} \mu \mathrm{g}$ and $22 \mathrm{pg} \mu \mathrm{g}$ of protein for the lines A and B, respectively (FDA, 1999a; BCH, 2012b).

Agritope along with Harris Moran Seed Company conducted field trials in the USA with both GM lines and their hybrids with non-GM varieties, and collected data on ripening time, fruit size, firmness, soluble solids and ethylene production. The results showed that ethylene production in both lines as well as in hybrids was reduced, but ripening time was extended by only three days in comparison with the control. Nonetheless, ripening proceeded more evenly. It was also observed that in transgenic fruit the concentration of soluble sugars was significantly higher than in control fruit, and correlated with the 1-3 day delay in ripening 
because of the fruit staying longer on the vine and being able to accumulate more sugars before harvest (Bommineni et al., 2000).

Agritope submitted petitions to APHIS in 1998 (APHIS, 1999) and to the FDA in 1999 to deregulate both GM A and B melon lines. Both lines received approval only for consumption in the USA in 1999 (FDA, 1999b) (Tab. 2). The petition to APHIS was withdrawn, thus the deregulation process was cancelled and the related documents are no longer available on the APHIS website. Thus, GM melon is not approved for cultivation although it is approved as food.

\section{Common bean}

The GM event Embrapa 5.1 (OECD UID: EMBPV051-1) of the common bean (Phaseolus vulgaris L.) was developed by Brazilian Agricultural Research Corporation (Embrapa) (Tab. 1). The aim of its modification was to develop a common bean resistant to a geminivirus - the Bean golden mosaic virus (BGMV). The BGMV causes stunted growth, pod malformation and mosaic depigmentation of leaves. The virus is transmitted by the tobacco whitefly (Bemisia tabaci) and causes substantial yield losses in Latin America, especially in summer months when the whitefly population expands. Commercially available cultivars cannot withstand the BGMV, thus it is necessary to develop other approaches for resistance improvement. The BGMV genome contains two single strands of DNA, DNA $\mathrm{A}$ and $\mathrm{B}$. The DNA-A contains $A C 1$ and $A C 3$ genes responsible for replication, and $A C 3$ replication enhancer, while DNA-B genes are responsible for virus spreading. Besides being a replication factor for the viral genome, the $\mathrm{AC} 1$ protein acts as its own regulator of expression (Raghavan et al., 2004).

The Embrapa 5.1 event was derived after particle bombardment of 'Olathe Pinto' embryonic axes with the pBGMVRNAiAHAS vector. The company chose RNAi technology for post-transcriptional silencing of the $A C l$ gene by introducing a dsRNA hairpin structure. The construct contained two copies of the $A C l$ gene in a sense and antisense orientation homologous to the BGMV rep gene fragment, with the CaMV 35S promoter and ocs terminator, and additionally the als gene from Arabidopsis thaliana encoding acetolactate synthase, which confers resistance to sulfonylurea and imidazolinone herbicides, with its own promoter and terminator. The 5.1 GM line was chosen from 18 transformants for further experiments, as it was the only one which showed resistance to the BGMV after plant infestation with virus-carrying whiteflies. This line was considered highly resistant because about $93 \%$ of plants remained symptomless after being exposed to over 300 whiteflies per plant per life cycle (Bonfim et al., 2007). In contrast, $100 \%$ of non-GM bean plants showed symptoms of virus infection when exposed to only 2-10 whiteflies under field conditions. The Embrapa Corporation also carried out tests with homozygous and hemizygous (backcross progeny) transgenic plants, and with non-transgenic plants. Two weeks after inoculation, $100 \%$ of transgenic plants were symptomless, about $28 \%$ of hemizygous population had mild symptoms, while all non-transgenic plants demonstrated severe disease symptoms. In the tests under field conditions conducted in 2007 and 2008 in Brazil, none of the transgenic plants were infected, while $18 \%$ of nontransgenic plants were infected in 2007 and $83 \%$ in 2008 (the highest average value of control plot) (Aragao and Faria, 2009).

Molecular analysis indicated that the gene construct was inserted in a single locus in the plant genome and remained stable for several generations, also after crossing with non-transgenic commercial cultivars. Further experiments suggested that one complete and three incomplete construct copies were integrated into the bean genome. In one locus, the two cassettes, AC1hpRNA and AHAS, were separated with a genomic DNA, which is notably quite common when using a biolistic transformation method (Dai et al., 2001; Aragao et al., 2013). The expression of the als gene occurred at a low level, thus the GM Embrapa 5.1 line could not be considered as herbicide tolerant.

The Embrapa 5.1 line did not show either phenotypic or compositional changes, and it had no adverse impact on the environment when compared to the non-GM common bean. The biosafety evaluation was conducted in a manner consistent with the Brazilian Normative Resolutions of the National Technical Biosafety Commission (CTNBio), which issued an opinion in 2011 that Embrapa 5.1 is save for cultivation, as feed and for consumption (CTNBio, 2011) (Tab. 2). The Embrapa 5.1 event was used to develop the first GM common bean cultivar in the world, known as BRS FC401 RMD registered (No. 34432) by the Brazilian Ministry of Agriculture, Livestock and Food Supply in 2015 (Embrapa, 2016).

\section{Chicory}

Hybrids have several advantages over openpollinated cultivars, i.e., they are uniform and 
usually perform better due to a heterosis effect. Hybrid breeding in chicory (Cichorium intybus L.) is possible due to plant self-incompatibility, a biological mechanism ensuring pollination control and preventing self-fertilization. However, the alleles determining self-incompatibility are unstable in chicory and the mechanism does not secure full pollination control, thus unmarketable hybrid seed lots can be produced. To overcome these difficulties, male sterile plants can be used as a maternal component in hybrid production, ensuring pure hybrid seed after cross-pollination with pollen of the male-fertile paternal line. Plant Genetic Systems in Belgium and Bejo Zaden BV in the Netherlands developed three chicory (radicchio rosso) GM events, RM3-3, RM3-4 and RM3-6, with introduced male sterility (Tab. 1).

These GM lines were derived as a result of Agrobacterium-mediated transformation of the RM3 breeding line with a gene construct ensuring anther-specific expression of the barnase gene encoding ribonuclease. The barnase enzyme cleaves the RNA, leading to its degradation. The construct contained this gene under the control of the pTa29 tapetum-specific promoter and nos terminator. The use of this promoter ensured Barnase expression in microspores and in the tapetum, the disruption of the tapetum cell layer function making anthers sterile. The construct also contained the Streptomyces hygroscopicus bar gene, conferring tolerance to glufosinate herbicide, with the pSsuAra-tp promoter highly active in green tissues and $3^{\prime}$ untranslated T-DNA gene 7 region, and additionally the $n p t \mathrm{II}$ gene with nos promoter and ocs terminator. The whole gene construct was introduced into the pTIM8RE plasmid, a derivative of pGV2260. Molecular analysis revealed that only the T-DNA region was present in the genome of developed transgenic plants, as no vector backbone DNA was detected. The stable transgene integration was confirmed by Southern blot analysis in T0 plants, their progenies and backcross progenies for five generations. In the RM3-3 and RM3-4 lines, one copy of the transgene was found and stable integration was confirmed, while the RM3-6 event had two transgene copies inserted separately. Only one of those inserts contained a functional bar gene, which remained stable through generations and in hybrids, while the second, non-functional, copy was lost in the first generation. Thus the final RM3-6 line possessed a single copy of the insert.

The company carried out greenhouse tests and extensive field evaluations of the GM lines and hybrids derived from them in Belgium, France, Italy, Netherlands, the United Kingdom and USA (California) in 1992-1996. The intended modification of flower male sterility was confirmed and no other morphological or agronomical changes were observed. Based on those experiments, some hybrids were chosen for potential cultivar registration by the General Netherlands Inspection Service for Flower and Vegetable Seeds (NAKG) (APHIS, 1997c).

The transgenic chicory received approval from the European Commission for placing it on the market in 1996 under the condition that it would be used for breeding purposes only and labelled that the seeds might be tolerant to glufosinate ammonium herbicide (EC, 1996). The evaluation of GM chicory as food and feed was made by the SCP. Favourable risk assessment was issued in 1998 (Tab. 2). In 1999, the Commission launched interservice consultations and, as a result, issued an opinion that it required an additional opinion from the SCF, and thus the Commission asked the SCF for evaluation. In 2000, in response to the SCF's request, the applicant submitted additional data on substantial equivalence from field trials, and a year later the SCF requested additional data on nutritional composition. While the consultations with the SCF were still in progress, the applicant stated that "the procedure, time, energy and costs are disproportionate compared to conventional breeding programs. This may lead to the conclusion that development and marketing of transgenic vegetable crops in the European Union do not have any opportunity" and withdrew the dossier in 2003 (WTO, 2008). In contrast to the long and incomplete procedure in the EU, the company successfully passed requirements in the USA. It started consultation with the FDA and also submitted a petition (No. 97-148-01p) to APHIS in 1997. A few months later, APHIS issued a positive assessment and approved GM chicory for cultivation, and the FDA approved it for food and feed use (APHIS, 1997d; FDA, 1997b). The approvals remain in force, but there is no register of GM chicory cultivation nowadays.

\section{Fruit trees}

\section{Papaya}

Papaya (Carica papaya L.) is a sole GM fruit tree species introduced into commercial production in 1996 and still cultivated and marketed. There are currently four GM papaya events approved and developed by scientists at either US or Chinese 
universities (Tab. 3). The first deregulated GM papaya were two events originated from the cultivar 'Sunset', the 55-1 event (OECD UID: CUH-CP551-8) and the 63-1 event (OECD UID: CUH-CP631-7), developed at the University of Hawaii and Cornell University, USA. At the same time, South China Agricultural University released 'Huanong No.1' event (not registered by OECD). The fourth event, deregulated in the USA and registered by the EPA in 2016, is X17-2 (OECD UID: UFL-X17CP-9) developed at the University of Florida. All four events are resistant to the Papaya ringspot virus (PRSV). The PRSV is an aphidtransmitted potyvirus, which causes visible rings on fruits, and mosaic, deformed, and smaller leaves. In consequence, tree growth is restricted, yields lowered, and young infected plants never produce fruit, with tree life span being reduced from 20 to usually a few years (Basso et al., 2016). The PRSV can also be spread by mechanical wounding during pruning, and by seed. Although transmittance by seed is rather marginal, it may contribute to the pathogen's dispersal and infection in new locations. There are no useful control measures to manage the PRSV. Even complete orchard eradication is ineffective, as some virus strains can persist in weeds, other perennial plants, and in annual plants, in particular those belonging to cucurbits. Some available papaya varieties are partially tolerant to selected virus strains, but still show disease symptoms. Papaya is grown in the tropics, and the PRSV affects almost all production regions. The virus spread rapidly on the Hawaiian Islands in the 1960s, first eliminating production on the Oahu island and then, in the 1990s, devastating plantations on the Puna island, thus almost completely abolishing fruit production and leading to a severe crisis in papaya farming and industry. At that time, in the late 1980 s, the research commenced at the University of Hawaii, USA, on virus coat protein (CP) and papaya genetic transformation had resulted in the development of the 55-1 and 63-1 GM events, which were introduced into fields with a hope of combating the disease (Gonsalves, 2004).

The 55-1 and 63-1 events were obtained after particle bombardment of embryogenic cultures derived from the gynodioecious cultivar 'Sunset' (Fitch et al., 1992). Transgenic plants were propagated and inoculated with a Hawaiian PRSV strain. The gene construct contained a chimeric PRSV CP gene, derived from the HA 5-1 strain, controlled by the CaMV 35S promoter and terminator, the uidA gene with the CaMV 35S promoter and nos terminator, and nptII with nos promoter and terminator (Tab. 4). The chimeric CP gene comprised the PRSV $c p$ gene, the $5^{\prime}$ untranslated region, and the $5^{\prime}$ fragment of the Cucumber mosaic virus (CMV) $c p$ gene to enhance translation of the mRNA by insertion of a translation initiation codon. This construct was inserted into the T-DNA of the pGA482GG/cpPRV-4 binary vector, which was used to coat tungsten particles for biolistic delivery. Southern analysis of the obtained transformants revealed that the 55-1 event contained all three $n p t I I$, uidA and PRSV $c p$ genes inserted in a single locus. They were expressed in leaves, as confirmed by ELISA and histochemical staining, but the level of CP in fruits was similar to that in a non-transgenic papaya. A partial and not expressing fragment of the vector backbone DNA was also identified. In the 63-1 event, a rearrangement of the inserted DNA occurred, as the uidA gene was neither expressed nor detected, in contrast to the $n p t I I$ and PRSV $c p$ genes. Other fragments of vector DNA located outside the T-DNA were also identified (APHIS, 1996d).

The development of the X17-2 event was achieved by $A$. tumefaciens-mediated transformation using the pBI121fs plasmid, a pBI121 derivative. The T-DNA of the plasmid contained the PRSV $c p$ gene from the H1K strain occurring in Florida, with the CaMV 35S promoter and nos terminator, and the $n p t I I$ gene accompanied by the nos promoter and terminator. The $c p$ gene had thymidine inserted at the $3^{\text {rd }}$ nucleotide downstream the ATG codon, resulting in a frame-shift mutation and an additional uidA leader at the 5' end. Molecular analysis of plants obtained from somatic embryos showed the presence of the gene construct in a single copy and persisting in the next progenies. No vector backbone was identified. Sequencing of the insert in plants of the fifth generation also revealed that the thymidine mutation in the $c p$ gene was reversed, enabling translation of the protein detectable by Western blotting, but not by ELISA, because the CP level was very low. Plants homozygous for the insert were identified by spraying with kanamycin and selecting those not exhibiting leaf bleaching (APHIS, 2008).

The Chinese variety 'Huanong No.1' was developed by $A$. tumefaciens-mediated transformation using the pRPTW binary plasmid containing the PRSV replicase gene (NIb) regulated by the CaMV $35 \mathrm{~S}$ promoter and nos terminator, and the $n p t I I$ gene under the control of the nos promoter and terminator (AFCD, 2015). 


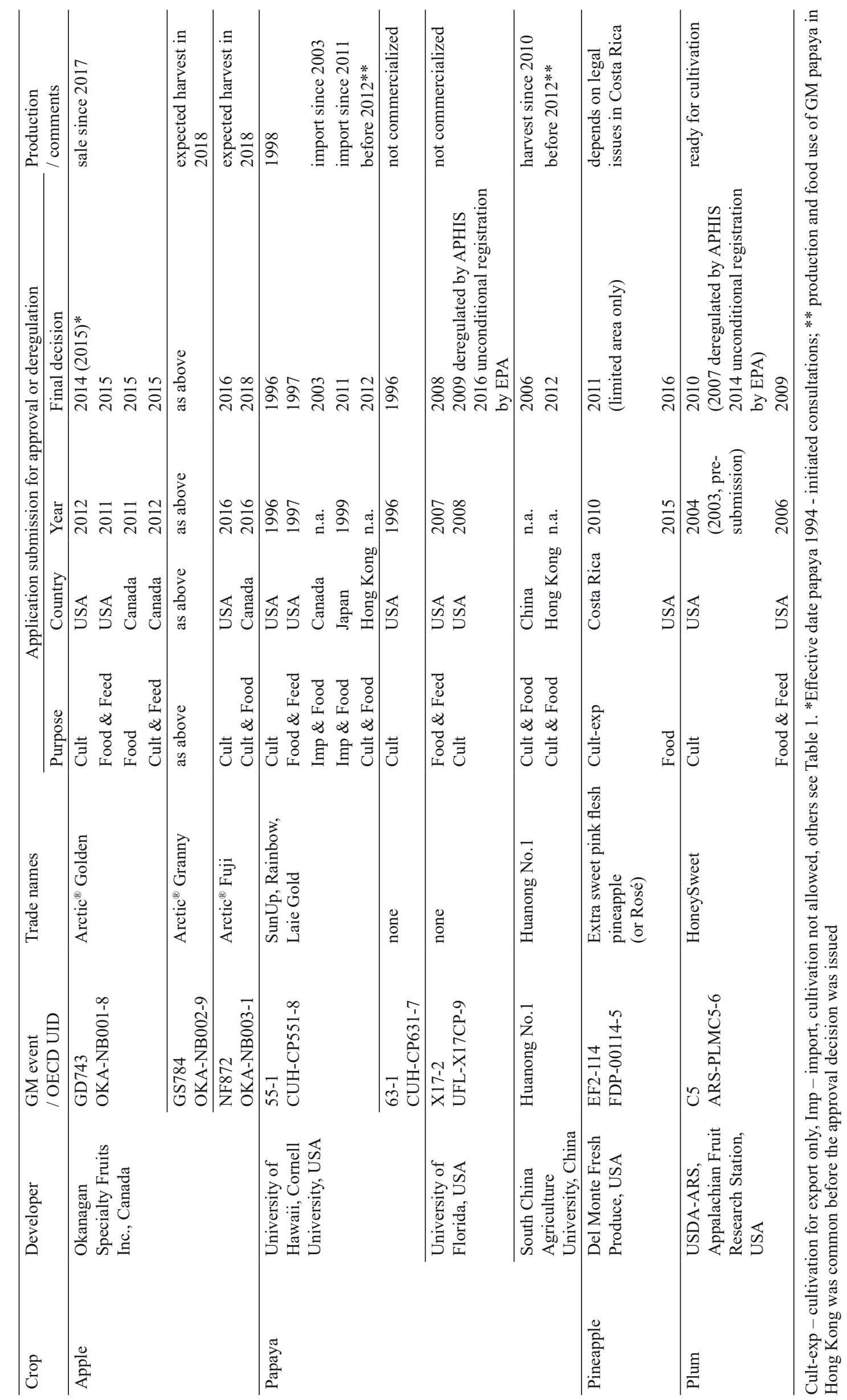




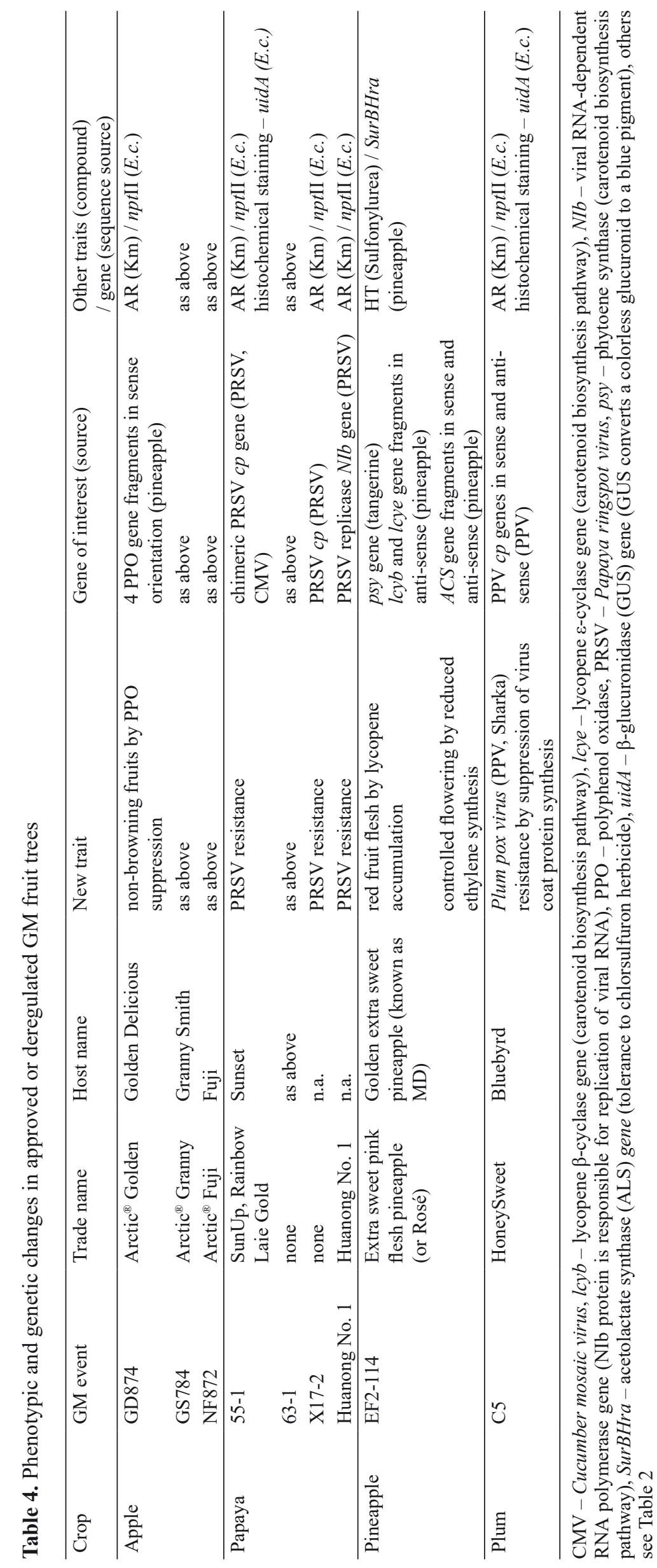


In a greenhouse resistance test, 55-1 and 63-1 plants were inoculated with the Hawaiian virulent PRSV HA strain. Only the 55-1 plants were uniformly disease-free for 6 months after inoculation. Field inoculation started in 1992, four months after planting. Non-GM plants showed symptoms within 20 days after mechanical inoculation and within 2-4 months when plants were left for infestation by aphids. They also showed increased susceptibility to root rot due to weaker foliage and thus reduced ability to remove soil moisture. After two years, those plants died. In contrast, the 55-1 plants showed mild PRSVinduced symptoms at first, but with time the symptoms diminished and the selected plants remained disease free and vigorous in a two-year experiment (APHIS, 1996d). Later tests showed that 55-1 plants were also resistant to other strains from Hawaii, but not to strains from other world regions. Some of 63-1 plants inoculated with various PRSV strains were also resistant to three Hawaiian strains and additionally to a virulent strain from Thailand (Tennant et al., 1994).

Five progenies of X17-2 obtained by pollination with non-GM varieties were evaluated in 1999-2007 for resistance to the PRSV strains $\mathrm{H} 1 \mathrm{~K}, \mathrm{H} 1 \mathrm{C}$, and H1A naturally occurring in Florida. They were resistant to $\mathrm{H} 1 \mathrm{~K}$ and tolerant to the other two strains, exhibiting only mild symptoms in contrast to nonGM plants that had severe disease symptoms. Thus hybrids developed from the PRSV-resistant X172 seem promising for papaya farmers in Florida (APHIS, 2008).

In 1996, the USDA's APHIS received a petition No. 96-051-01p from Cornell University and the University of Hawaii stating that the 55-1 and 63-1 events should not be regulated because they did not present a plant pest risk, and the agency deemed the petition rational after the completion of an environmental assessment (APHIS, 1996d, 1996e). The next year, the FDA closed the consultations, concluding that the 55-1 "new papaya line is not materially different in composition, safety, or other relevant parameters from papaya varieties currently on the market and that it does not raise issues that would require premarket review or approval by FDA" (FDA, 1997c). The 63-1 event was not a subject of FDA consultations. Analogous consultations concerning the X17-2 event were closed by the FDA in 2008 (FDA, 2008) and the event was deregulated in the USA in 2009 (APHIS, 2009a, 2009b). In 2016, the EPA registered the X17-2 papaya as a new PIP (Plant Incorporated Protectant; registration No. 84427-1) in accordance with FIFRA section 3(c)(5) (EPA, 2016). In 2002, Health Canada concluded that the varieties 'Rainbow' and 'SunUp' derived from the 55-1 event "present no human food safety concerns" and that they were "as safe and nutritious as currently available commercial papaya varieties", thus approving their import and use as food (HC, 2003). Japan approved the 55-1 event in 2011 for import and food use, too (GAIN, 2016d), and Hong Kong lifted the ban on GM papaya in 2012, surrendering to the fact that over half of the papaya market was already GM and that GM trees were commonly grown (AFCD, 2015).

Resistant 55-1 plants were used to develop a homozygous PRSV-resistant 'SunUp' producing red-fleshed fruits. Then, 'SunUp' was crossed with a non-GM 'Kapoho', the dominant variety in Hawaii, and a desired yellow-fleshed 'Rainbow', a hemizygous F1 hybrid, was obtained. Both GM 'SunUp' and 'Rainbow' were proved resistant to the PRSV in field conditions and produced high quality fruits (Gonsalves, 2004). Other varieties of lesser significance in global production were later obtained by crossing GM and non-GM papaya. An example is a micropropagated 'Laie Gold', a hybrid between 'Rainbow' F2 and the non-GM 'Kamiya', characterized by initially higher yields and shorter trees (Gonsalves et al., 2004).

The Papaya Administrative Committee, a papaya growers' organization, received licence agreements from the owners of intellectual property rights involved in developing GM papaya in 1998. Seeds of the deregulated 'SunUp' and 'Rainbow' were distributed to Hawaiian farmers for free in the same year, and the first harvest was in 1999. 'Rainbow' plants were the ones mainly appreciated due to a yellow fruit flesh. At the beginning of the next decade, about $40 \%$ of the papaya-growing land was covered with 'Rainbow' trees. The adoption of GM PRSV-resistant varieties rescued the papaya production in Hawaii, which first dropped from 26 thousand tons in 1992, when the PRSV occurred, to 16 thousand tons in 1998. After GM papaya seed was released in 1998, the production was restored, just in three years, to 24 thousand tons in 2001, mainly due to the cultivation of 'Rainbow' trees, which yielded 25 times more fruit than the non-GM 'Sunrise' (Ferreira et al., 2002; Gonsalves, 2004). By the end of the decade, the production in the USA had been reduced to about 14,000 tons from over 500 ha as a result of global market changes, but still $82 \%$ of Hawaiian papaya plantations were GM varieties, predominantly 'Rainbow' (Evans 
et al., 2015). In $2015,95 \%$ of almost 4,000 tons of US papaya for export was produced in Hawaii and marketed mainly in Canada (74\% of US papaya export), Japan (11\%), Hong Kong (5\%) and other countries (USDA, 2015b).

Hawaiian farmers are uncertain of their future production, as several attempts to ban or restrict any GM plants in Hawaiian counties have commenced in recent years, and a restrictive anti-GMO bill was enacted in 2013. Whether the bill affects the current GM papaya production remains unclear, but in 2016 the bill was overturned in an appeal in the U.S. Court of Appeals for the Ninth Circuit. Currently, GMO crops, including papaya, continue to be legally grown in Hawaii (AP, 2016).

The Chinese Ministry of Agriculture approved the release of 'Huanong No. 1' in 2006, and commercial production started in 2010 in Guangdong Province. In two years, about $95 \%$ of papaya grown in this province were GM trees. In the next years, 'Huanong No. 1' production was extended also to Hainan Island and Guangxi Province, and the GM trees were grown in total on almost 8475 ha in 2014 (James, 2014; Puette, 2016), but on 6700 ha according to the USDA (GAIN, 2014), and on 8550 ha in 2016 (ISAAA, 2016a).

Several PRSV-resistant GM papaya events have been developed in Taiwan as well, but their commercial production is not regulated due to the lack of GMO law in Taiwan, thus they are not registered by the OECD. The known events are 16-0-1 and 18-2-4 (or TW-lines) obtained by $A$. tumefaciens-mediated transformation and possessing an insert with the PRSV $c p$ gene and $n p t I$ gene (Yeh et al., 2011). The $c p$ gene expression ensures resistance to the PRSV YK strain from Taiwan. TW-lines have been identified in the fields in China and are available on the market. Papaya seeds with the same insert were also found in seed lots imported to Japan in 2011 and 2014, and trees of unapproved GM events were identified in the fields, and were consequently cut down according to Japanese regulations (BCH, 2014d). Japan had approved import of the 55-1 papaya only, and the process took almost 12 years. Individually labelled GM 'Rainbow' fruits from Hawaii were displayed in Japanese shops just 10 days after the final decision announced in December 2011 (GAIN, 2011). However, due to a low significance of papaya on the Japanese market and an advantageous price of the Philippine papaya, the sale of fresh Hawaiian GM fruits is marginal in Japan now (GAIN, 2016d).
GM papaya has also been found on the market as well as in local gardens in Hong Kong. In a survey of GMOs, carried out in 2011 - March 2015, 61\% of 117 fruits sampled in the market and 54\% of 1386 sampled trees were GM. Depending on the year, $60-80 \%$ of GM material were TW-lines, $15-24 \%$ were 'Huanong No. 1', and 0-25\% were varieties with the 55-1 event (fruits only) (AFCD, 2015). The next years' (2015/2016) survey showed similar frequencies of GM fruits on the market and growing trees $(68 \%$ out of 50 sampled and $56 \%$ out of 43 sampled, respectively) (AFCD, 2017). Unauthorized papaya was also reported in imports from Thailand to the EU, Japan and India, although the cultivation of GM plants in Thailand is not allowed (USDA, 2015b).

\section{Plum}

Only one GM plum (Prunus domestica L.) variety is currently approved for cultivation and food use (Tab. 3). 'HoneySweet' (C5 event, OECD UID: ARS-PLMC5-6) (Scorza et al., 2004), developed by the USDA-ARS Appalachian Fruit Research Station, is a plum variety with medium-to-large fruits (about $60 \mathrm{~g}$ ) with a deep purple and waxy skin, yellow flesh and an almost free stone. It is resistant to the Plum pox virus (PPV) causing the Sharka disease. Sharka causes severe damage in stone fruit orchards and is considered the most dangerous plum disease, which was first recorded in Bulgaria in 1917. Infected trees produce deformed fruits, and up to $90 \%$ of fruits may drop before maturity, making them unsuitable for consumption or processing (Scorza et al., 2013). Annual yield losses due to PPV infection are estimated at 1.5 million tons in Europe only, and the total cost of managing this disease worldwide has exceeded 10,000 million euros in the last 30 years (Cambra et al., 2006). Sharka occurs worldwide and management strategies are restricted to the elimination of PPV sources and vectors. The main control approach involves eradication programmes, which in some countries, such as the USA, have restricted PPV dispersion, at least temporarily (Rimbaud et al., 2015).

'HoneySweet' was developed by A. tumefaciensmediated transformation of hypocotyl slices in vitro. Hypocotyls were excised from seedlings obtained after pollination of self-incompatible 'Bluebyrd' with pollen of an unknown parent. The pGA482GG/ PPV-CP-33 vector in the C58/Z707 A. tumefaciens strain carried the PPV strain D $c p$ gene, the $n p t I I$ and $\beta$-glucuronidase (uidA) genes, the latter two referred to as selection and reporter genes, respectively 
(Tab. 4). The $c p$ and $u i d A$ genes were controlled by the CaMV 35S promoter and A. tumefaciens nopaline synthase (nos) polyA signal was used to terminate the transcription of all three genes. Expression of the uidA gene allows easy validation of the presence of the insert in a GUS tissue-staining assay as well as checking of gene transfer events in sexually derived progenies. Kanamycin resistance was essential in the development process in vitro for the selection of events containing the introduced transgenes. After selection and regeneration, the transgenic shoot (No. C5) was rooted, and successfully passed the initial greenhouse resistance tests after inoculation with the PPV strains D and M transferred by aphids. Then, buds of the C5 clone were grafted onto different non-transgenic rootstocks. The mechanism of resistance to the PPV in 'HoneySweet' relies on a post-transcriptional gene silencing, thus the PPV coat protein is not expressed and not present in any tree cells. Restriction analysis and sequencing revealed that the genetic transformation had led to imperfect multicopy insertion of the gene construct into the plum genome. Five genetic structures were identified, in close proximity of which an inverted PPV-CP sequence repeat is essential. It accompanies another PPV-CP in correct orientation, thus the presence of both drives the formation of dsRNA. This RNA species can be degraded to short interfering RNAs, key factors ensuring further degradation of the whole target RNA molecules. Thus in 'HoneySweet', the degradation of PPVCP RNA, transcribed on the inserted transgenes, takes place, which ensures constitutive resistance response also upon PPV infection and transcription of de novo introduced viral RNA. 'HoneySweet' is a hemizygote at the PPV-CP locus due to selfincompatibility and vegetative propagation. However, the PPV-CP transgene can be transmitted in pollen to other compatible recipients, which enables production of Sharka-resistant progenies useful in further breeding efforts (Scorza, 2006).

Field evaluations of 'HoneySweet' trees, lasting for six-to-ten years, in Spain, Poland, Romania, and the Czech Republic, where the PPV is endemic, have confirmed tree resistance to the PPV. Under natural infection by the PPV transmitted by aphids, 'HoneySweet' showed no disease symptoms, and after inoculation using PPV-infected grafts, only mild symptoms occurred. When infected 'HoneySweet' budwood was used for grafting, or scions were grafted on infected rootstocks, only mild symptoms on the leaves in the lower tree part were observed. The symptoms diminished in consecutive years, thus the disease did not spread systematically. Resistance to the D, M, El Amar and Sour Cherry PPV strains has been confirmed (Scorza, 2006). Recently published results of 12year field evaluations in the Czech Republic support these conclusions and show additionally that the resistance remains stable if trees are co-infected with the PPV-Rec strain and the Prune dwarf virus (PDV) and the Apple chlorotic leaf spot virus (ACLSV) (Polak et al., 2017).

'HoneySweet' was deregulated by APHIS in 2007 (APHIS, 2007a, 2007b), and in January 2009 the FDA closed consultations and concluded that plums derived from this variety "are not materially different in composition, safety, and other relevant parameters from plums currently on the market and that genetically engineered plum line C5 does not raise issues that would require premarket review or approval by FDA" (FDA, 2009). In 2010, the EPA registered 'HoneySweet' as a new PIP (Plant Incorporated Protectant; registration No. 113128 ) in accordance with FIFRA section 3(c)(5) for one year (EPA, 2010). The conditional registration was later extended two times, after which the final unconditional registration was issued in 2014 (EPA, 2014). The decision imposes no restriction on 'HoneySweet' cultivation and food use in the USA.

Due to the severity of damage caused by the PPV and no chemical control being effective in either preventing or eliminating the PPV, with the elimination of infected trees as the only control option, Sharka continues to pose a considerable threat. In the USA, Sharka was found in Pennsylvania in 1999, 10-year eradication programme that cost $\$ 65$ million solved the problem in orchards there. In 2000, Sharka was found in Canada, but a similar eradication programme was not successful and did not prevent localized PPV appearance in New York State. Nowadays, however, 'HoneySweet' is not commercially cultivated in the USA although small demonstration fields have been established. Despite the cultivar having been patented in the USA, the developer, the USDA-ARS, has made it freely available for both fruit production and as a source of PPV resistance, thus it can be used in future (Scorza et al., 2016).

\section{Pineapple}

Genetically modified pineapple (Ananas comosus (L.) Merr.) was developed by a US company Del Monte Fresh Produce Company (Tab. 3). The only GM variety approved to date, the 'Extra sweet pink flesh pineapple' (EF2-114 event, OECD UID: FDP- 
00114-5), is a modified MD2 ('Del Monte Gold extra sweet pineapple') variety, a common variety contributing to the extent of $90 \%$ to worldwide exports. 'Extra sweet pink flesh pineapple' was originally patented (Firoozbady and Young, 2015), two years after the submission in 2013, under the name 'Rosé' and is commonly denoted as the GM EF2-114 event. It has intended modifications that result in a red or pink fruit flesh due to carotenoid accumulation, and in flowering control. The characteristic flesh colour is conferred mainly by a health-promoting red lycopene accumulated there at a mean level of $21 \mathrm{ppm}$, which is comparable to the level in other red-coloured fruits such as tomato, watermelon, grapefruit and papaya (Wawrzyniak et al., 2005). The new red colour is also attractive to consumers and enables easy visual differentiation between the GM and traditional yellow pineapple. Flowering control is essential for programmed production and was achieved by suppressing the expression of ACS in meristems, a key enzyme in ethylene biosynthesis (see the description in the section on tomato).

This GM pineapple was developed through A. tumefaciens-mediated transformation. Two T-DNA gene constructs were designed, and introduced separately into the GV3101 (pMP90) A. tumefaciens strain. The first plasmid, pHCW.T-7, comprised four cassettes: 1) the phytoene synthase (psy) gene from tangerine (Citrus unshiu), coding for the enzyme at the first step of lycopene biosynthesis, 2) and 3) a partial coding fragment of the $\beta$-lycopene cyclase $(L c y b)$ and $\varepsilon$-lycopene cyclase (Lcye) genes in the sense and anti-sense orientation, and 4) a mutant acetolactate synthase (ALS) gene from tobacco (SuRBHra), conferring chlorsulfuron resistance due to the replacement of two amino acids in the wild type ALS molecule (Table 4). The second plasmid, pHCWflACC3'-2, contained a partial coding fragment of the pineapple meristem $A C S$ gene (flACC $3^{\prime}$ ) in the sense and anti-sense orientation. Anti-sense sequences enable RNAi and post-transcriptional gene silencing. In consequence, the expression of the LCYB and LCYE enzymes is suppressed, thus lycopene is accumulated, as it is not converted to $\beta$-carotene nor $\alpha$-carotene, respectively. Except for $p s y$ and SuRBHra genes, and a small potato intron, all the other DNAs, including the sense and anti-sense fragments, promoters, terminators and flanking sequences, originated from pineapple. Thus, the transgenic material has all the introduced DNAs originating from edible plants and only one gene from tobacco. The latter gene codes for the ALS protein, with over $90 \%$ homology to the ALS enzymes present in other edible Solanaceae species.

The initial material for transformation were MD-2 shoots cultured in vitro. Excised leaf-base sections were simultaneously co-cultivated with two bacterial strains, which resulted in the co-delivery of T-DNA fragments from both the pHCW.T-7 and pHCWflACC3'-2 plasmids. After several transfers and micropropagation, chlorsulfuron-tolerant clones were selected. They were grown for the first time in 2008. The next year, plants were cultivated in a greenhouse in Costa Rica for 15-20 weeks and then transferred into soil in field trials, where they were grown for 16-18 months, induced to flower by ethylene application, and then had their fruits harvested and characterized for the selection of elite clones. Plants of the best performing clone, the EF2-114 event, were morphologically similar to the MD2 variety; their fruits had a so-called tiger-shell colour (a combination of green-yellow-orange-red colours resulting from the expression of carotenoid genes in the shell), and the intended pink or red flesh colour. The fruits had a high lycopene content and reduced $\beta$-carotene. The levels of some constituents such as potassium, vitamin $C$, sucrose and leucine differed from those measured in the MD2 variety, but they were within the ranges of values reported for pineapple varieties.

Molecular analyses of the EF2-114 revealed up to four copies of the introduced vector fragments, including at least one intact construct from the pHCW.T-7 plasmid, while other copies were rearranged. The genetic insertion was stable over four vegetative generations. The introduced genes were expressed, while the expression of the endogenous $L c y b$ and $L c y e$ genes was reduced, as expected. In contrast, no conclusive data were obtained for ACC expression, but further field trials showing the lack of a wild-type flowering phenotype in EF2-114 plants indicated successful delivery and expression of the responsible fragments.

The developer had intended to grow GM pineapple in Costa Rica, and its subsidiary, LM Veintiuno, obtained a permit from the National Technical Commission on Biosafety of the Ministry of Livestock and Agriculture in 2011 to plant an area of up 200 ha. Under this permit, field trials resulted in a multi-year evaluation of the EF2-114. Production from those fields in Costa Rica is allowed for export only and has reached 226 ha in 2016 (ISAAA, 2016a). In the USA, the FDA evaluated regulatory and safety issues regarding human food 
derived from the EF2-114 pineapple variety. In December 2016, the agency closed consultations, concluding that there were no unresolved safety or regulatory issues under the Federal Food, Drug, and Cosmetic Act for the genetically engineered pink flesh pineapple, as this new variety did not differ in characteristics from other commercially available pineapple, except in the intended higher lycopene content (FDA, 2016). Therefore, 'Extra sweet pink flesh pineapple', the GM EF2-114 event, can enter the US market once its production starts in Costa Rica. Whether commercial production starts depends on the outcome of the legal disputes that are currently underway in Costa Rica.

\section{Apple}

Genetically modified apple (Malus $\times$ domestica Borkh.) varieties have become a reality nowadays. A small Canadian biotech company, Okanagan Specialty Fruits Inc. acquired by American Intrexon Corporation in 2015, has developed three $\operatorname{Arctic}^{\circledR}$ apple varieties that have already been allowed for cultivation and consumption (Tab. 3). All three varieties: 'Arctic ${ }^{\circledR}$ Golden' (GD743 event, OECD UID: OKA-NB001-8), 'Arctic ${ }^{\circledR}$ Granny' (GS784 event, OECD UID: OKA-NB002-9) and 'Arctic ${ }^{\circledR}$ Fuji' (NF872 event, OECD UID: OKA-NB003-1), produce fruits which do not brown when cut, sliced, bitten or bruised due to the inhibited enzymatic process of oxidative browning commonly occurring in injured apple fruits. Such fruits, trees producing them, and the method of obtaining them have been patented (Armstrong and Lane, 2011). Oxidative browning occurs as a result of the activity of polyphenol oxidases (PPOs). These enzymes convert phenolic compounds to quinones in the presence of oxygen, and the resulting quinones polymerize to form brown melanins. Chlorogenic acid, epicatechin, and catechin are major apple polyphenol substrates for PPOs, but other polyphenols can be converted by PPOs as well (Yoruk and Marshall, 2003). Browning contributes largely to postharvest and processing fruit loss, reduced shelf-life, and is also unappreciated by consumers of fresh and sliced apples. Chemical treatment and storage in a low oxygen atmosphere may reduce browning. Arctic ${ }^{\circledR}$ apples have a demanding non-browning phenotype due to the silencing of four PPO genes using RNAi.

Arctic $^{\circledR}$ apples were developed using A. tumefaciens-mediated transformation of leaf segments excised from in vitro cultivated plantlets of the common varieties: 'Golden Delicious', 'Granny
Smith' and 'Fuji'. The A. tumefaciens EHA105 strain contained a disarmed binary GEN-03 vector, a derivative of pBINPLUS and pBIN19 plasmids. The DNA fragment of GEN-03 contained essentially two cassettes. The first, containing the $n p t I I$ gene under the nos promoter and terminator control, ensured kanamycin resistance of plantlets exposed to this antibiotic in vitro (Tab. 4). The second cassette was composed of the duplicated-enhancer CaMV 35S promoter and nos terminator flanking the $1.81 \mathrm{~kb}$ chimeric PGAS insert constructed of four 394-457 bp long apple PPO gene fragments in the sense orientation. These fragments were obtained from the PPO2, GPO3, APO5, and pSR7 genes representing four groups of a large PPO family. The PGAS transcript was intended to reduce the expression of the entire apple PPO gene family in a transgenic plant by the silencing approach using RNAi after transcript processing into small 21-23 nt interfering RNAs (siRNAs), which, due to sequence homology, caused direct cleavage of target PPO mRNAs. After the transformation, the leaf segments were exposed to the selection medium for shoot regeneration and micropropagation. Plantlets with over $80 \%$ suppressed PPO activity were further selected and characterized at a molecular level. Finally, the selected events were micrografted onto the $\mathrm{M} 9$ rootstock and planted for field evaluation in field conditions (APHIS, 2012).

Southern analyses revealed that 'Arctic ${ }^{\circledR}$ Golden' contained two unlinked T-DNA insertions, while 'Arctic ${ }^{\circledR}$ Granny' contained four unlinked copies. 'Arctic ${ }^{\circledR}$ Fuji' contained multiple insertions in three chromosomes, as revealed by the whole apple genome sequencing using the Illumina technology. In CHR13 there were two tandem inverted insertions in a head-to-head orientation, while in CHR17 there was a tail-to-tail insertion of one complete and a fragment T-DNA without PPO genes. Chromosome 3 had the same insertion arrangement as in CHR13, accompanied by the $1.4 \mathrm{~kb}$ vector backbone sequence free of any functional elements. All three varieties had an inserted nptII gene expressing only one new functional protein, i.e. NPTII, essential for selection of transgenic events during the development procedure. This protein was found in leaves, but did not accumulate in mature fruits. Fruits of the Arctic $^{\circledR}$ varieties did not differ essentially from those of donor varieties with regard to moisture, calories, sugar profile, protein, carbohydrates, dietary fibre, and potassium contents. Significant changes were observed for compounds with antioxidant 
capacity, i.e., vitamin $\mathrm{C}$ and total polyphenolics, whose levels were elevated, although they fell within the range of or close to the apple reference nutrient values (NDB09003) provided by the USDA National Nutrient Database for Standard Reference (USDA, 2016). Higher levels of phenolics were a result of suppressed PPO activity, ranging from 90\% in 'Arctic ${ }^{\circledR}$ Golden' to $96 \%$ in 'Arctic ${ }^{\circledR}$ Fuji' in comparison with their non-GM counterparts. In consequence, ORAC values, which show an extract's capacity to absorb oxygen radicals, were also higher, as tissues were richer in phenolics. Also, the level of vitamin $\mathrm{C}$ increased due to inhibited enzymatic oxidation. Increased levels of phenolic compounds can potentially affect the susceptibility to pests and diseases. Multi-year field trials with GD743 and GS784 in Washington and New York States (2003-2012), and with NF872 in New York State (2005-2015) did not deliver data on essential change in pest and disease occurrence on $\operatorname{Arctic}^{\circledR}$ trees in orchards with implemented integrated pest management. A non-browning phenotype of injured fruits was the main aim of modification. Bruising, either at $2^{\circ} \mathrm{C}$ or $18^{\circ} \mathrm{C}$, resulted in almost no visible flesh colour changes after $3 \mathrm{~h}$, while the control fruits of 'Golden Delicious' and 'Granny Smith' had clearly visible brown tissue at the sites of injury. An analogous difference was observed for sliced fruits stored in sealed bags at $5^{\circ} \mathrm{C}$ for 3 weeks and for fresh juice left overnight at room temperature.

The approval procedure for 'Arctic ${ }^{\circledR}$ Golden' and 'Arctic ${ }^{\circledR}$ Granny' varieties was initiated in Canada in 2011. Safety assessment of GD743 and GS784 as novel food was carried out by Health Canada. It was determined that "the changes made to the apple did not pose a greater risk to human health than apples currently available on the Canadian market" and ,the Arctic apple would have no impact on allergies, and that there are no differences in the nutritional value of the Arctic apple compared to other traditional apple varieties available for consumption". Therefore, Health Canada concluded that "food derived from Arctic Apple events GD743 and GS784 is as safe and nutritious as food from current commercial apple varieties" (HC, 2015). Both varieties were also considered as plants with novel traits, and in 2012 their evaluation was started by the Plant Biosafety Office of the Plant Health and Biosecurity Directorate, Plant Health Science Directorate and the Animal Feed Division of the Animal Health Directorate. The unconfined release into the environment and the use as livestock feed was then issued by the Canadian Food Inspection
Agency in 2015 (CFIA, 2015). Any apple varieties derived from 'Arctic ${ }^{\circledR}$ Golden' and 'Arctic ${ }^{\circledR}$ Granny' may also be released into the environment and used as food and feed. Analogous approval for 'Arctic ${ }^{\circledR}$ Fuji' was issued by Health Canada in 2018 (HC, 2018).

In the USA, the deregulation process started in 2012. The USDA's APHIS, based on consultations with PPRA, EA and FONSI, concluded in 2014 that GD743 and GS784 plants are unlikely to pose a plant pest risk, would have no significant impacts on the quality of the human environment and on endangered species, including their habitats, and issued a decision on the deregulation of these two non-browning apple varieties (APHIS, 2014), with effective date in 2015 (APHIS, 2015). In 2015, the FDA concluded the consultations, stating that "events GD743 and GS784, and the foods and feeds derived from them are not different in composition, safety, or any other relevant parameter from comparable apple varieties now grown, marketed, and consumed in the U.S." (FDA, 2015). In 2016, the USDA also deregulated 'Arctic ${ }^{\circledR}$ Fuji' after evaluating the developer's petition to extend the determination of non-regulated status that had already been granted to the other $\operatorname{Arctic}^{\circledR}$ apple varieties (APHIS, 2016a).

Okanagan Specialty Fruits planted 70,000 'Arctic ${ }^{\circledR}$ Golden' and 'Arctic ${ }^{\circledR}$ Granny' trees on 80 ha of land in the USA in 2016 and contracted another 800,000 trees to be planted in the following two years. Annual yield from these trees is expected to exceed 13 thousand tons at full orchard maturity. The first harvest from commercial production was announced in 2017, and first bags of sliced 'Arctic ${ }^{\circledR}$ Golden' apples entered the market at selected retailers in the mid-West. The company has announced the launch of the next Arctic apple, 'Arctic ${ }^{\circledR}$ Gala', the fourth non-browning variety, in the near future (FFP, 2017).

\section{Ornamental plants}

\section{Petunia}

Petunia (Petunia $\times$ hybrida L.) has been a model ornamental plant for research on engineering biosynthesis pathways and a pioneer GM species in field trials. The petunia GM RL01-17 event, with a modified flower colour, was developed by the Max Planck Institute for Plant Breeding Research (MPIPZ) in Germany in 1987 and then patented in 1995 (Meyer et al., 1995). It was characterized by an orange, often described as brick-red, flower colour not present in conventional cultivars. The orange 
GM petunia event was obtained by introducing the maize $A l$ gene through genetic transformation with the p35A1 plasmid into protoplasts isolated from the RL01 mutant possessing low amounts of anthocyanins, and with only a $9 \%$ share of pelargonidin (Meyer et al., 1987). The plasmid contained the maize $A 1$ gene under the control of the CaMV 35S promoter. Additionally, the plasmid contained the nptII gene under the control of a nos promoter. The $A 1$ gene encodes the dihydroflavonol 4-reductase (DFR) enzyme, which in the aleurone tissue of the maize kernel converts dihydroquercetin into leucocyanidin and dihydrokaempferol into leucopelargonidin, the precursors of cyanidin and pelargonidin, respectively, enabling biosynthesis of coloured derivatives (Fig. 2). The maize DFR can recognize both dihydroquercetin and dihydrokaempferol, but it preferentially converts dihydroquercetin. Thus, the biosynthesis of pelargonidin can be carried out only in the absence of dihydroquercetin (Griesbach, 2007). The expression of the $A 1$ gene in the RL01 petunia resulted in a 10 -fold increase in the total amount of anthocyanins, including pelargonidin constituting up to $55 \%$ of these compounds, which was manifested in flower colour change from a pale pink to brick red (Griesbach, 1993). Northern blot analysis of the transgenic plant revealed a high expression of the $A 1$ gene inserted into the petunia genome as a single copy. Intensely orangepigmented flowers were observed only during growth in the greenhouse. In outdoor cultivation, the expression was silenced due to methylation in some of the tested plants (Meyer and Heidmann, 1994).

Initially, 30,000 RL01-17 transgenic plants were evaluated in Germany by the Max Planck Institute. In the next years (1996 and 1997), small numbers of petunia plants were authorized for release in demonstration gardens (COGEM, 2017; BCH, 2018a, 2018b). GM petunia had not been intended for official authorization and cultivation in the EU or USA, as its flowers were too small and not attractive, and the colour was not stably expressed. However, the licence for petunia modification was acquired by two companies, related to the Dutch

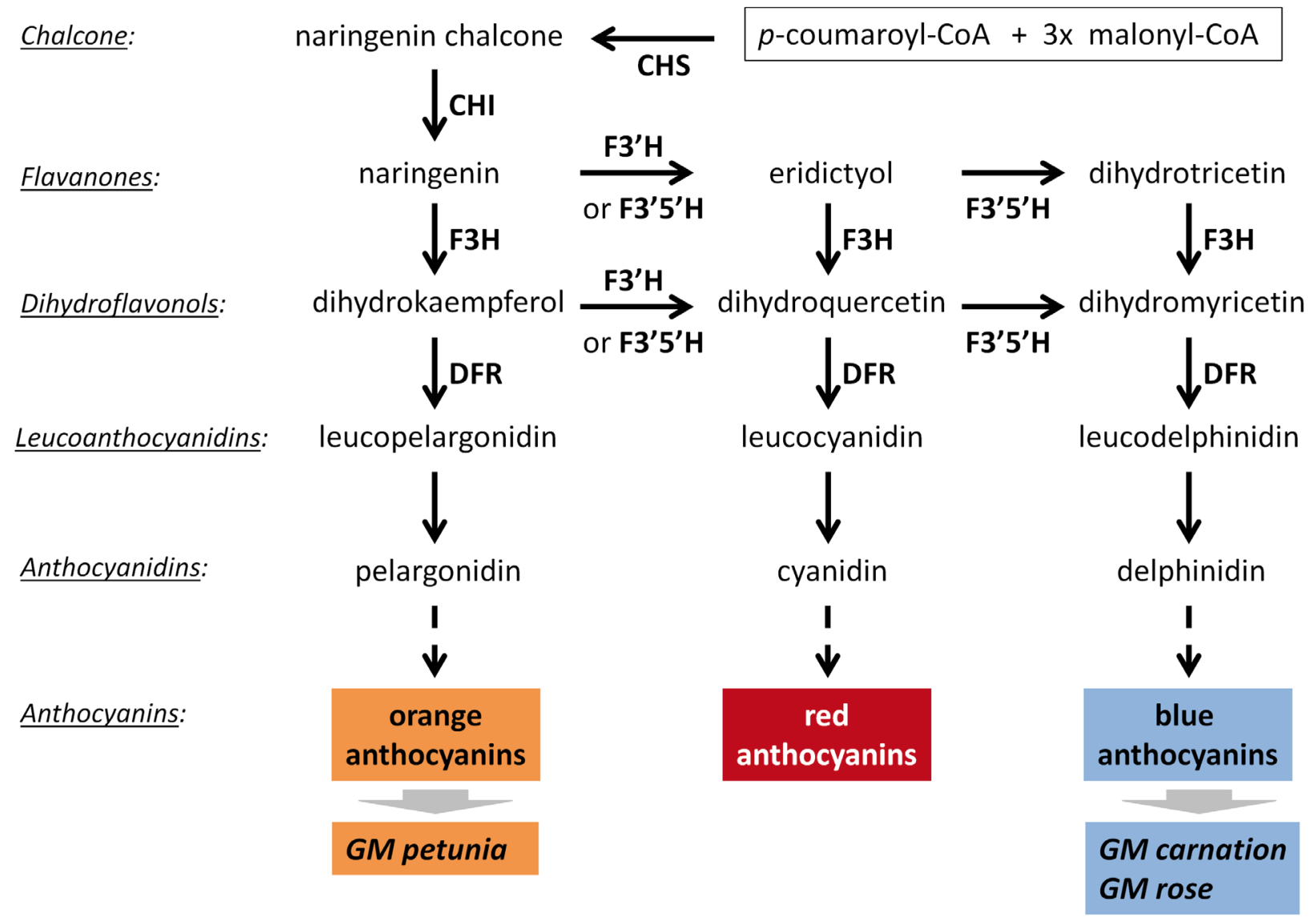

Figure 2. A simplified flavonoid biosynthesis pathway being a target for genetic engineering to modify the accumulation of anthocyanin pigments and hence the flower colour. CHS - chalcone synthase, $\mathrm{CHI}$ - chalcone isomerase, $\mathrm{F} 3 \mathrm{H}-$ flavanone 3-hydroxylase, F3'H - flavonoid 3'-hydroxylase, F3'5'H - flavonoid 3',5'-hydroxylase, DFR - dihydroflavonol 4-reductase 
Zaadunie seed company, S\&G Seeds and Rogers $\mathrm{NK}$, and the latter also got permission for field trials with GM petunia in Florida. Zaadunie was owned by Sandoz, which merged with Novartis, and the latter, together with AstraZeneca, formed Syngenta, which has recently been acquired by ChemChina, a Chinese state-owned enterprise. These owner and shareholder changes over the years coincide with the presence of orange petunia cultivars that are common worldwide and that so far have not been considered as genetically modified. Orange non-GM petunias are also known in Europe, and they have been available on the market, but brightorange petunias resembling the GM RL01-17 were spotted in flower boxes at the Helsinki railway station in 2017, and samples of them were subjected to molecular analyses to verify a possible presence of an unauthorized modification (Bashandy and Teeri, 2017). After receiving an inquiry, the Finnish Food Safety Authority, and later also the Dutch Human Environment and Transport Inspectorate, performed biochemical and molecular analyses of this material and other orange petunias available on the market. The results confirmed that the petunias from Helsinki contained foreign DNA fragments, which were very similar to those used 30 years earlier by the developer of the GM RL0117 event (Servick, 2017b). Unexpectedly, two other commercial varieties, 'African Sunset' and 'Bonnie Orange', contained pelargonidine as the main anthocyanidin, and a gene construct with the maize $A 1$ gene, CaMV $35 \mathrm{~S}$ promoter and $n p t \mathrm{II}$ gene, also like the RL01-17 event. Origins of the identified transgenic DNA other than the RL01-17 event are possible, as in the past there had been reports on the development of orange GM petunias in Finland and Japan. To date, cultivated GM petunias have been identified in Belgium, Germany, Great Britain, the Netherlands, Switzerland, Australia and the USA, indicating that they have been available on the market for about 30 years (Servick, 2017a). Currently, more than 100 petunia cultivars are recognized as GM or potentially GM, and require import authorization into the USA under the same Biotechnology Regulatory Services regulations as other GM events (APHIS, 2017a). Moreover, producers and gardeners are advised to destroy unauthorized plants, so several producers have announced the withdrawal of these cultivars. Risk assessments issued so far indicate that GM petunias with an altered flower colour pose a negligible risk to humans and the environment, as summarized by the Netherlands Commission on Genetic Modification, thus the withdrawal is a consequence of the lack of any authorization and not due to safety concerns (COGEM, 2017).

Later, a new cultivar, known as Petunia-CHS, was also developed by a Sinobioway Group's subsidiary Xiamen Bioway Biotech Co. Ltd., a Beijing University-owned enterprise (Tab. 5). There is no official information on this GM event except that the intended modification was the development of a petunia with a white flower. This phenotype was achieved by the introduction of another copy of a plant chalcone synthase (CHS) gene coding for a key enzyme at an early step of the flavonoid biosynthesis pathway, thus the flower decoloration was most probably achieved by RNAi. China issued permission for Petunia-CHS commercial release into the environment in 1998, and limited cultivation is probably carried out in Beijing Municipality and Fujian Province (Puette, 2016).

\section{Carnation}

Carnation (Dianthus caryophyllus L.) is the first ornamental GM plant placed on the market almost 25 years ago and still being sold in selected countries around the world. Thirteen commercial GM cultivars of the Moon series, developed by Florigene, Suntory Flowers and International Flower Developments, have been approved for cultivation and production so far (Tab. 5). Florigene Pty Ltd. was founded when the Australian Calgene Pacific (founded from Calgene Inc., which had developed the Flavr Savr ${ }^{\mathrm{TM}}$ tomato) bought the Dutch Florigene BV in 1993. Later, the company cooperated with Japan's Suntory Ltd. on advanced research and development of new modified flowers and became its subsidiary in 2003. Finally, both companies established a joint International Flower Developments Pty Ltd. (IFD). Therefore, all three companies are listed as the developers or owners of GM carnation, and also of GM rose, developed in various periods ( $\mathrm{Lu}$ et al., 2003). GM carnation cultivars were developed in response to persistent demands for blue coloured flowers, which could not be achieved by conventional breeding due to the lack of naturally occurring blue pigments in this species. Over the years, many attempts had been made to obtain blue flowers; however, only some of them resulted in a stable accumulation of blue anthocyanins derived from delphinidin (Fig. 2), and thus they have been successfully commercialized (Gonnet and Fenet, 2000). 
Table 5. Approved or deregulated GM ornamental plant events in the world - part 1

\begin{tabular}{|c|c|c|c|c|c|c|c|}
\hline \multirow[t]{2}{*}{ Crop } & \multirow[t]{2}{*}{ Developer } & \multirow{2}{*}{$\begin{array}{l}\text { GM event } \\
\text { / OECD UID }\end{array}$} & \multirow[t]{2}{*}{ Trade name } & \multirow[t]{2}{*}{ Host name } & \multicolumn{3}{|c|}{ Approval decision } \\
\hline & & & & & Purpose & Country & Year \\
\hline \multirow[t]{52}{*}{ Carnation } & \multirow{52}{*}{$\begin{array}{l}\text { Florigene/ } \\
\text { Suntory/ } \\
\text { International } \\
\text { Flower } \\
\text { Developments }\end{array}$} & 4 & \multirow[t]{2}{*}{ Moondust } & \multirow[t]{2}{*}{ White Unesco } & Cult & Australia & 1995 \\
\hline & & FLO-ØØØØ4-1 & & & Cult & Norway & 1998 \\
\hline & & 11 & \multirow[t]{3}{*}{ Moondust } & \multirow[t]{3}{*}{ as above } & Cult & Australia & 1995 \\
\hline & & FLO-Ø7442-5 & & & Cult & Japan & 2004 \\
\hline & & & & & Cult & Norway & 1997 \\
\hline & & 15 & \multirow[t]{2}{*}{ Moondust } & \multirow[t]{2}{*}{ as above } & Cult & Australia & 1995 \\
\hline & & FLO-ØØØ15-3 & & & Cult & Norway & 1997 \\
\hline & & 16 & \multirow[t]{2}{*}{ Moondust } & \multirow[t]{2}{*}{ as above } & Cult & Australia & 1995 \\
\hline & & FLO-ØØØ16-4 & & & Cult & Norway & 1997 \\
\hline & & 123.2 .38 & \multirow[t]{5}{*}{ Moonlite } & \multirow[t]{5}{*}{ Cream Cinderella } & Cult & Japan & 2004 \\
\hline & & FLO-40644-6 & & & Cult & Australia & 2007 \\
\hline & & & & & $\operatorname{Imp}$ & Malaysia & 2012 \\
\hline & & & & & Cult-exp & Colombia & 2000 \\
\hline & & & & & $\operatorname{Imp}$ & EU & 2007 \\
\hline & & 25947 & Moonpearl & Cerise Westpearl & Cult-exp & Colombia & 2008 \\
\hline & & IFD-25947-1 & & & Imp & Malaysia & 2012 \\
\hline & & $1226 \mathrm{~A}$ & Moonshade & Cream Cinderella & Cult & Norway & 1998 \\
\hline & & FLO-11226-9 & & & Cult & EU & $1998 *$ \\
\hline & & & & & Cult-exp & Colombia & 2000 \\
\hline & & 123.2 .2 & Moonshade & as above & Cult & Japan & 2004 \\
\hline & & FLO-04Ø619-8 & & & $\operatorname{Imp}$ & Malaysia & 2012 \\
\hline & & & & & Cult & Australia & 2007 \\
\hline & & $1351 \mathrm{~A}$ & Moonshade & as above & Cult & Norway & 1998 \\
\hline & & FLO-11351-8 & & & Cult-exp & Colombia & 2000 \\
\hline & & $1400 \mathrm{~A}$ & Moonshade & as above & Cult & Norway & 1998 \\
\hline & & FLO-114ØØ-3 & & & Cult-exp & Colombia & 2000 \\
\hline & & $959 \mathrm{~A}$ & Moonshade & as above & Cult & Norway & 1998 \\
\hline & & FLO-11959-4 & & & Cult & EU & $1998 *$ \\
\hline & & & & & Cult-exp & Colombia & 2000 \\
\hline & & $988 \mathrm{~A}$ & Moonshade & as above & Cult & Norway & 1998 \\
\hline & & FLO-11988-6 & & & Cult & EU & 1998 \\
\hline & & $1363 \mathrm{~A}$ & Moonshadow & Unesco & Cult & Norway & 1998 \\
\hline & & FLO-11363-2 & & & Cult & EU & $1998 *$ \\
\hline & & & & & Cult & Japan & 2004 \\
\hline & & & & & Cult & Australia & 2007 \\
\hline & & 26407 & Moonvelvet & Cerise Westpearl & CultG-exp & Colombia & 2008 \\
\hline & & IFD-264Ø7-2 & & & $\operatorname{Imp}$ & Malaysia & 2012 \\
\hline & & & & & $\operatorname{Imp}$ & Australia & 2015 \\
\hline & & & & & $\operatorname{Imp}$ & EU & 2015 \\
\hline & & 123.8 .8 & Moonvista & Cream Cinderella & Cult & Japan & 2004 \\
\hline & & FLO-4Ø685-2 & & & Cult & Australia & 2007 \\
\hline & & & & & Imp & Malaysia & 2012 \\
\hline & & $199 \varnothing 7$ & Moonique & Kortina Chanel & CultG-exp & Colombia & 2008 \\
\hline & & IFD-19907-9 & & & $\operatorname{Imp}$ & Malaysia & 2012 \\
\hline & & 123.8 .12 & Moonaqua & Cream Cinderella & $\operatorname{Imp}$ & EU & 2009 \\
\hline & & FLO-4Ø689-6 & & & Cult & Japan & 2009 \\
\hline & & & & & $\operatorname{Imp}$ & Malaysia & 2012 \\
\hline & & & & & $\operatorname{Imp}$ & Australia & 2015 \\
\hline & & 25958 & Moonberry & Cerise Westpearl & CultG-exp & Colombia & 2008 \\
\hline & & IFD-25958-3 & & & Imp & Malaysia & 2012 \\
\hline & & & & & $\operatorname{Imp}$ & Australia & 2015 \\
\hline & & & & & $\operatorname{Imp}$ & EU & 2015 \\
\hline
\end{tabular}


Table 5. Approved or deregulated GM ornamental plant events in the world - part 2

\begin{tabular}{|c|c|c|c|c|c|c|c|}
\hline \multirow[t]{2}{*}{ Crop } & \multirow[t]{2}{*}{ Developer } & \multirow{2}{*}{$\begin{array}{l}\text { GM event } \\
\text { / OECD UID }\end{array}$} & \multirow[t]{2}{*}{ Trade name } & \multirow[t]{2}{*}{ Host name } & \multicolumn{3}{|c|}{ Approval decision } \\
\hline & & & & & Purpose & Country & Year \\
\hline & & 66 & none & & Cult & Australia & 1995 \\
\hline & & FLO-ØØØ66-9 & & & Cult & Norway & 1998 \\
\hline & & 27531 & Moontea & Cream Cinderella & $\operatorname{Imp}$ & EU & 2016 \\
\hline & & SHD-27531-4 & & & & & \\
\hline Petunia & $\begin{array}{l}\text { Beijing } \\
\text { University }\end{array}$ & Petunia-CHS & none & n.a. & Cult & China & 1998 \\
\hline \multirow[t]{7}{*}{ Rose } & Suntory/ & WKS82/130-9-1 & Applause & WKS82 & Cult & Japan & 2008 \\
\hline & Florigene & IFD-529Ø1-9 & & & CultG & Colombia & 2010 \\
\hline & & & & & Cult & USA & 2011 \\
\hline & & WKS82/130-4-1 & Applause & WKS82 & Cult & Japan & 2008 \\
\hline & & IFD-524Ø1-4 & & & Cult & Australia & 2009 \\
\hline & & & & & CultG & Colombia & 2010 \\
\hline & & & & & Cult & USA & 2011 \\
\hline
\end{tabular}

Cult - cultivation, CultG - cultivation in greenhouse only, -exp - for export only, Imp - import, cultivation not allowed, others see Table 1. *Expired in 2008; renewal filed

'Moondust' (events 4, 11, 15, 16; OECD UIDs are listed in Table 5) (Holton, 1996) was the first GM carnation with a new pale mauve flower colour (code $75 \mathrm{~A}$ according to the Royal Horticultural Society (RHS) Colour Chart) approved for cultivation in 1996 (Tab. 6). Two years later, the next cultivar, 'Moonshadow' (event 1363A) with purple-violet flowers was approved. In subsequent years, further cultivars were developed and approved: mauve 'Moonaqua' (event 19907), lavender 'Moonlite' (event 123.2.38), light lavender 'Moonpearl' (event 25947), purple-violet 'Moonshade' (events 959A, 988A, 1226A, 1351A, 1400A, 123.2.2) and 'Moonique' (event 19907), deep purple 'Moonvista' (event 123.8.8), 'Moonvelvet' (event 26407), and light lavender 'Moonberry' (event 25958). In 2016, 'Moontea' (event 27531) with burgundypurple flowers was approved. Two other bi-colour carnations, purple 'Moonstrike' with variegated stripes and 'Moonburst' with lavender stripes, are advertised by Florigene Ltd., but there is no information either on their current status or what genetic modification they possess. 'Moondust' was obtained from a double $D F R$ and $F 3^{\prime} H$ (flavonoid 3'-hydroxylase) mutant 'White Unesco', developing white flowers of midi type (Fig. 3). Another cultivar with similar flowers, 'Unesco', a single DFR mutant, was used to obtain 'Moonshadow'. A creamy 'Cream Cinderella', a DFR mutant but with standard type flowers, was used to develop 'Moonlite', 'Moonvista', 'Moonshade', 'Moonaqua' and 'Moontea' with light purple to deep purple or burgundy-purple flowers. In turn, 'Moonpearl', 'Moonberry' and 'Moonvelvet' GM carnations with spray-type flowers were developed from 'Cerise Westpearl', a variety synthesizing pelargonidin due to a mutation in the $F 3^{\prime} H$ gene. 'Moonique', also a spray carnation, was developed from 'Kortina Chanel', which synthesized cyanidin (Tanaka et al., 2009; Tanaka and Brugliera, 2013).

Analogously as in the case of petunia, colour change in carnation was obtained by engineering anthocyanin biosynthesis, in particular, by altering the delphinidin pathway branch resulting in the accumulation of blue pigments. One of the most effective approaches was the use of white carnation in which dihydroflavonol 4-reductase was deficient. As a result, the introduction of petunia $D F R$ and $F 3^{\prime} 5^{\prime} H$ (flavonoid 3'5'-hydroxylase) genes induced the accumulation of delphinidin derivatives, thereby producing bluish flowers in 'Moondust' (Fig. 2). The same gene construct was inserted into creamy 'Cream Cinderella', resulting in 'Moonlite' and 'Moonshade'. A number of experiments have shown that a change of the $F 3^{\prime} 5^{\prime} H$ gene sources may result in increased accumulation of delphinidin derivatives. Thus the $F 3^{\prime} 5^{\prime} H$ gene from pansy (Viola $\times$ wittrockiana) was introduced to obtain 'Moonshadow'. The same strategy, utilizing a combination of petunia and pansy genes, was subsequently used to obtain 'Moonaqua', 'Moonvista' and 'Moontea', with the difference that 'Cream Cinderella', instead of white 'Unesco', was used as the host cultivar. This versatile system for midi and standard carnations was unfortunately not working in spray-type flowers. To modify flowers of this type, coloured cultivars accumulating pelargonidin or cyanidin derivates were used. The 


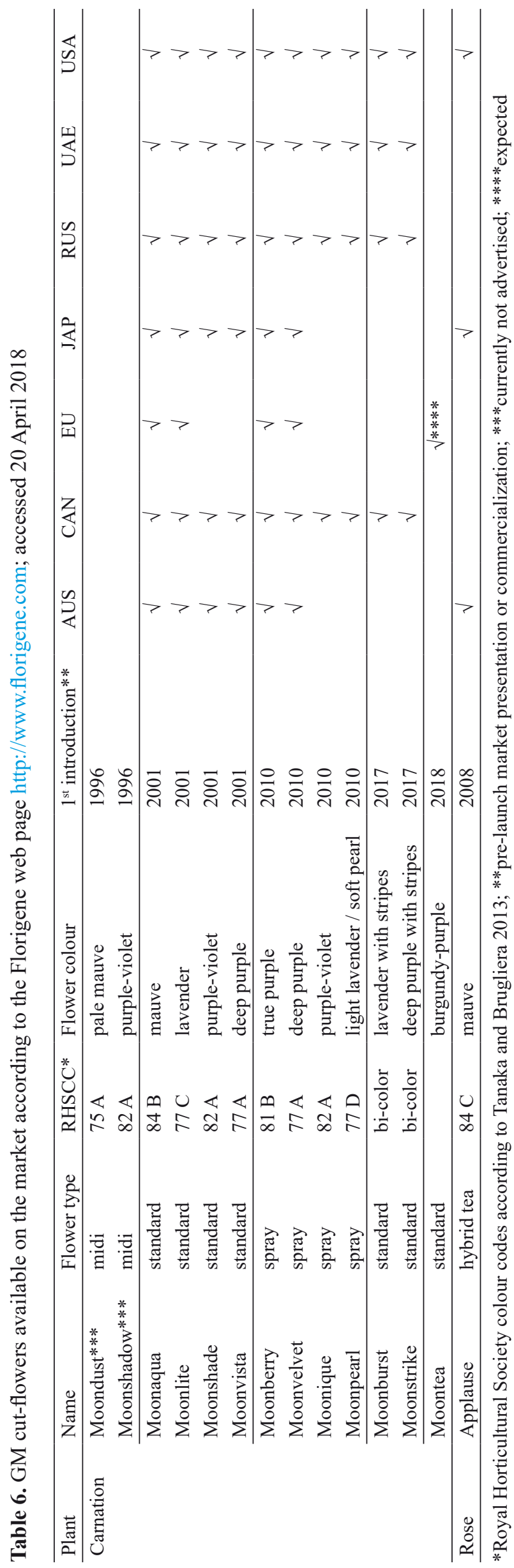

introduction of two $F 3^{\prime} 5^{\prime} H$ genes, from pansy and blue salvia, together with a petunia $D F R$, into a cyanidin-producing 'Kortina Chanel' resulted in dark purple flowers of 'Moonique' carnation. An RNAi approach was utilized to obtain 'Moonberry' and 'Moonpearl' from 'Cerise Westpearl' by the introduction of pansy $F 3^{\prime} 5^{\prime} H$ and two $D F R$ genes from petunia and carnation. A hairpin structure of carnation DFR silenced the endogenous gene, while the expression of new pansy $\mathrm{F}^{\prime} \mathrm{J}^{\prime} \mathrm{H}$ together with petunia DFR enzymes ensured the desired colour change. Using the same host cultivar, but a different genetic concept, 'Moonvelvet' with a deep purple spray-type flower was obtained. In 'Moonvelvet', two petunia genes were inserted, the $F 3^{\prime} 5^{\prime} H$ and cytochrome $b_{5}$, the latter being able to specifically transfer electrons to $\mathrm{F}^{\prime}{ }^{\prime}{ }^{\prime} \mathrm{H}$, enhancing enzyme activity (Tanaka and Brugliera, 2013).

GM carnation cultivars were obtained using A. tumefaciens AGL0 strains containing different binary plasmids, i.e., the pCGP1470 plasmid ('Moondust', 'Moonlite', 'Moonshade'), pCGP1991 ('Moonshadow', 'Moonvista', 'Moonaqua', 'Moontea'), pCGP3366 ('Moonberry', 'Moonpearl'), pCGP2442 ('Moonique') or pCGP2355 ('Moonvelvet'), with a cloned $F 3^{\prime} 5^{\prime} H$ gene derived from petunia, pansy or salvia, and a $D F R$ gene from petunia or carnation, as listed above (Fig. 3). The T-DNA region of the pCGP1470 plasmid contained a petunia $D F R$ gene controlled by a constitutive hybrid Mac promoter and mas terminator, the $F 3^{\prime} 5^{\prime} H$ gene from petunia regulated by a chs promoter from snapdragon (Antirrhinum majus) and terminated by a petunia $\mathrm{D} 8$ terminator. In the pCGP1991 plasmid, the petunia DFR gene was also present, but it was regulated by its own promoter and terminator. In turn, the $F 3^{\prime} 5^{\prime} H$ gene was obtained from pansy, but the regulators remained unchanged. The pCGP3366 plasmid was similar to the pCGP1991, but additionally possessed a hairpin-forming construct containing the sense and antisense fragments of carnation $D F R$ separated by a $D F R$ intron sequence from petunia and the CaMV $35 \mathrm{~S}$ terminator, resulting in downregulation of endogenous $D F R$. The pCGP2442 plasmid delivered two $F 3^{\prime} 5^{\prime} H$ genes, one from pansy (regulated by carnation anthocyanidin synthase (ANS) promoter and terminator) and another from salvia (regulated by a chs promoter and D8 terminator like in the pCGP1470 plasmid). This plasmid also harboured the petunia DFR gene, the same as in the pCGP1991 plasmid. The plasmid pCGP2355 contained the petunia $F 3^{\prime} 5^{\prime} H$ 


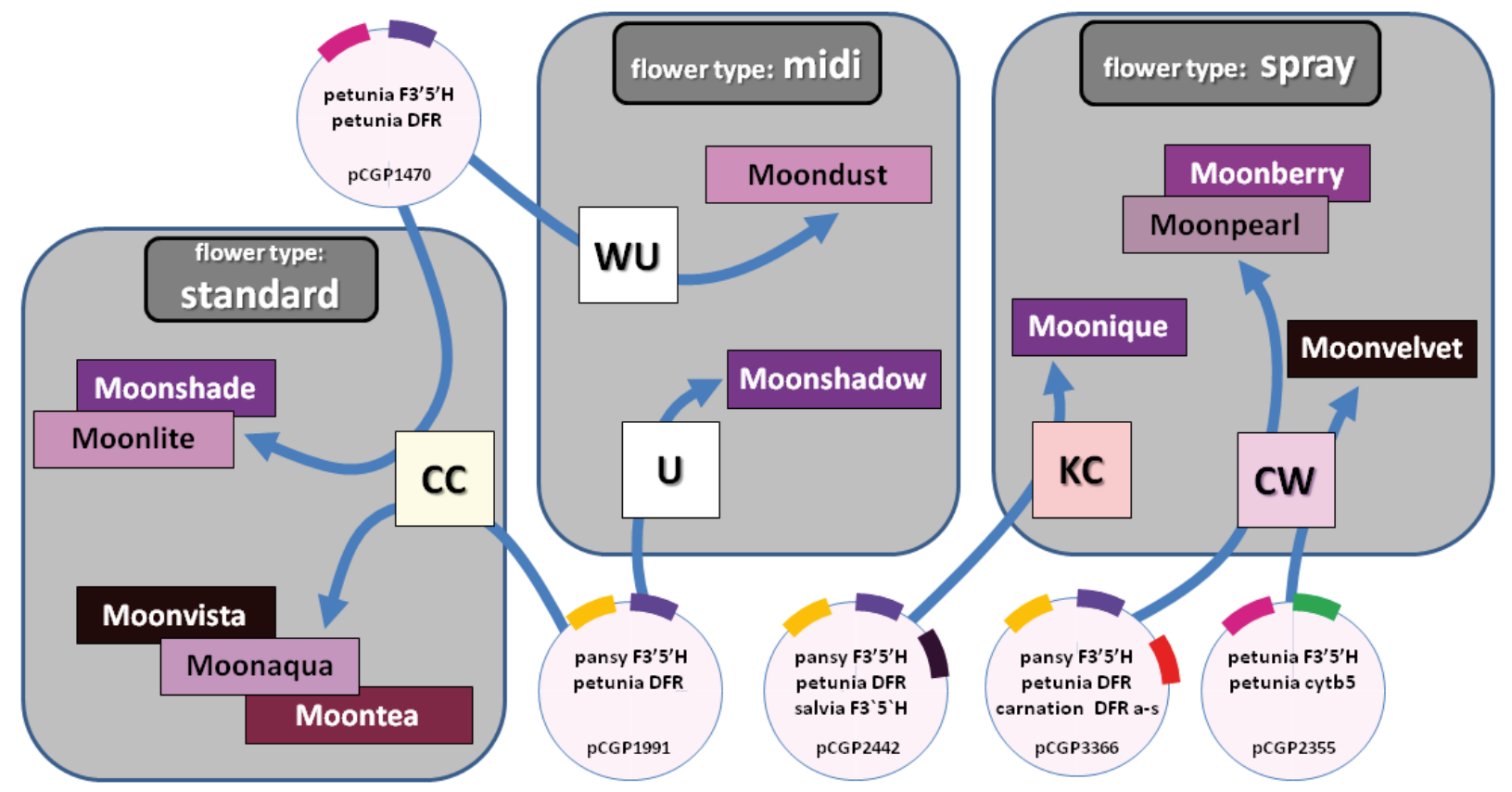

Figure 3. Development of GM carnation cultivars. Arrows indicate which gene constructs (circles) are introduced by genetic transformation to host cultivar (squares) resulting in GM cultivars with a modified colour (rectangles). Field colour relates to flower colour. Large grey boxes arrange host and GM cultivars depending on the flower type: midi, spray or standard. The introduced genes and their sources are marked in circles representing plasmids. Host cultivar: CC - 'Cream Cinderella', CW - 'Cerise Westpearl', KC - 'Kortina Chanel', U - 'Unesco', WU - 'White Unesco'; genes: a-s - antisense sequence orientation, genes: cytb5 - cytochrome $b_{5}$, DFR - dihydroflavonol 4-reductase , F3'5' H - flavonoid 3'5'-hydroxylase

gene regulated by carnation ANS promoter and terminator, and petunia cytochrome $b_{5}$ cDNA and regulated by a CHS promoter and D8 terminator. All the listed plasmids also possessed a selectable marker gene, the tobacco $A L S$ gene coding for acetolactate synthase, with its own terminator and regulated by the CaMV 35S promoter (JRC EU, 2007; Tanaka and Brugliera, 2013).

The obtained GM cultivars differ in flower colour due to the altered total amount of anthocyanidins. The anthocyanidin content in deep purple 'Moonvista' and 'Moonvelvet', and in purple-violet 'Moonique' reached 1.82-3.26 mg $\mathrm{g}^{-1}$ of petals as determined in hydrolyzed extracts. Light lavender 'Moonpearl', mauve 'Moonaqua' and lavender 'Moonlite' had even 100 times less anthocyanidins. The colour variation also resulted from the relative share of the blue pigment fraction, delphinidin and its coloured derivates, in the total amount of anthocyanidins. Cultivars with a more intense hue, 'Moondust', 'Moonshadow', 'Moonvista', 'Moonshade' and 'Moonique', contained at least $90 \%$ of delphinidin derivatives out of the total anthocyanidins detected in hydrolyzed petal extracts. A smaller share (60-75\%) of these pigments was detected in light purple 'Moonpearl',
'Moonaqua' and 'Moonlite' (OGTR, 2015b; Tanaka and Brugliera, 2013).

Besides the Moon-series, Florigene developed a carnation event (event 66; OECD UID FLO-00066 -9) exhibiting improved vase life. It was obtained by inserting a truncated carnation $A C S$ gene, analogously to what had been done in the 1345-4 tomato event with delayed ripening. In carnation, the expression of the $A C S$ gene was regulated by the constitutive CaMV $35 \mathrm{~S}$ promoter and nos terminator. The introduced copy of $A C S$ caused the suppression of the native gene expression and thus reduced the level of ACC. In consequence, ethylene production was reduced, which resulted in a longer cut-flower life. The vase life of this GM carnation, reaching up to 22 days, was almost doubled in comparison with cut flowers of the conventional cultivars (Savin et al., 1995).

All the carnations described above additionally have the $A L S$ gene with its own terminator from tobacco under the control of the CaMV 35S promoter with the petunia $C a b 5^{\prime} \mathrm{UTR}$. In plants, ALS is responsible for the first step of the amino acid biosynthesis (Keeler et al., 1993) and its activity can be suppressed by herbicides such as sulfonylureas, imidazolinones and triazolopyrimisines. The 
introduced tobacco $A L S$ gene variant, $S u R B$, contains a point mutation making the ALS enzyme significantly less sensitive to herbicides (Green, 2009).

For the first time, the 66 event with improved vase life was authorized for general release (GR-1) in Australia in 1995 under the former voluntary system. In the same year, the Moonseries carnations obtained after transformation with the pCGP1470 and pCGP1991 plasmids were also authorized for general release (GR-2) including cultivation in Australia. In 1997, the USDA's APHIS deregulated the same GM events covered by the Australian GR-2 licence, making import into the USA legal without need for labelling, and they have been sold in the USA to this day. At the same time, cut flowers were also approved for import into Canada and for growing in Ecuador, with the restriction that cut-flowers were for export only (Nap et al., 2003; OGTR, 2003b). A new Gene Technology Act 2000 came into force in Australia in 2001. Under its regulations, any GM event, including those already approved, had to be assessed and licensed to be legally produced or distributed after the end of the transition period in 2003. In 2002, Florigene submitted the relevant application to continue commercialization of cultivars already covered by GR-2, and in the next year it was granted a licence for commercial production and distribution of four cultivars: 'Moonshade', 'Moonlite', 'Moonshadow' and 'Moonvista' (OGTR, 2003a). These cultivars were finally included on the GMO register in 2007 and, since then, they can be used by anyone without need for a licence for the propagation, growth, and distribution of GM plants and cut flowers Australia-wide (OGTR, 2007). Notably, these carnations have been the only dealings included on the Australian GMO register so far. Three newer cultivars, 'Moonaqua', 'Moonberry' and 'Moonvelvet', were licensed in 2015 for import and distribution of cut flowers in Australia without permission for growing (OGTR, 2015a). Similarly, 'Moondust', 'Moonvista', 'Moonlite', 'Moonshade' and 'Moonshadow' were approved under the Cartagena Protocol domestic Law in Japan in 2004 and 2009 for release and cultivation (JCH, 2004a, 2004b, 2004c, 2004d, 2009). In Colombia, GM carnations were approved in 2000 and 2008 for cultivation in greenhouses only and for export of cut flowers (ICA, 2000, 2008). In Malaysia, the National Biosafety Board issued in 2012 permission for import and use of eight GM carnation cultivars for ornamental purposes (NBB, 2012). In Norway,
'Moondust' (Notification reference C/NL/96/1411), 'Moonshadow' (Notification ref. C/NL/97/13) and event 66 (Notification ref. C/NL/97/12) were approved for placing on the market under the $90 / 220$ / EEC directive. 'Moondust' was then cultivated between 1998 and 2000 in the Netherlands and Spain, from where it was exported and sold in other European countries (COGEM, 2007). In subsequent years, other cultivars were approved for import and placing on the EU market in accordance with specific EC decisions, i.e., 'Moonlite' (EC, 2007), 'Moonaqua' (EC, 2009), 'Moonberry' (EC, 2015a), 'Moonvelvet' (EC, 2015b) and 'Moontea' (SHD27531-4; Notification ref. C/NL/13/01) (EC, 2016). Some countries, such as Israel, Mexico, Kenya and Singapore, also approved selected carnation cultivars for general release, but no information on their commercialization has been reported (OGTR, 2003b).

Carnations are grown on a massive scale by vegetative reproduction using axillary buds from mother plants. After rooting, plants are transferred to soil or grown in hydroponic conditions for 1-2 years. During the production, seeds are not formed and pollen is not released because the flowers are cut off before full bloom. GM carnations are grown commercially only by Florigene on two farms located in South America. Flores Luna Nueva in Colombia produces 20 million cut flowers hydroponically each year in a nine-hectare greenhouse, with about $2 / 3$ production of standard-type and $1 / 3$ of spray-type carnations. Flores Equinocciales S.A. is located exactly on the equator, close to Quito, the capital of Ecuador. Its production is estimated at 10-25 million stems. Only large carnations are produced in the soil on this farm consisting of six 1 ha greenhouses (Vellekoop, 2015). GM carnations, together with a GM blue rose described in the next section, were planted on 12 hectares in 2015 in Colombia (GAIN, 2016b). According to the information in the application, 39.4 million 'Moonaqua', 3.2 million 'Moonberry', and 2.9 million 'Moonvelvet' stems were produced in Colombia in the years 2000-2014 (OGTR, 2015b). Earlier information available at the Office of the Gene Technology Regulator indicates that before 2003 Australian growers produced up to 2 million cut flowers and 100,000 plants annually (OGTR, 2003b), and, according to the Agricultural Biotechnology Council of Australia, more than 4.5 million GM carnation flowers were sold in that country in 1995-2012 (ABCA, 2012). Florigene reports that stems produced in Colombia and Ecuador are exported currently to seven countries 
and are offered by florists in Australia, Canada, the EU (counted as a single country), Japan, Russia, the United Arab Emirates and the USA, but cultivar availability depends on the approval status in a given country (Tab. 6).

\section{Rose}

Genetically modified rose (Rosa $\times$ hybrida L .) was developed by a Japanese company, Suntory Ltd., in cooperation with Australian Florigene Ltd. To date, two genetically modified events have been approved: WKS82/130-4-1 (OECD UID: IFD-524Ø1-4) and WKS82/130-9-1 (OECD UID: IFD-529Ø1-9). Both were obtained from the WKS82 parent plant with pink petals (RHS Colour Chart number: 75B). The intended modification was to obtain mauve flowers as a response to ornamental plant market demands resulting from a clear lack of a blue or purple rose, but also carnation, chrysanthemum and gerbera. The lack of a bluish flower colour in these plants is due to an inactive biosynthetic pathway leading to the production of delphinidin-derived anthocyanins (Fig. 2), thus the obtained GM rose events had an altered anthocyanin biosynthesis resulting in increased accumulation of delphinidin and its derivatives (Tanaka et al., 2009).

The GM events listed above were obtained by co-cultivation of leaf-derived callus and A. tumefaciens harbouring the pSPB130 plasmid (Katsumoto et al., 2007). This plasmid contained a T-DNA cassette including three genes, the $F 3^{\prime} 5^{\prime} H$ and anthocyanin 5-aromatic acyltransferase (5AT) gene, each of them under the control of enhanced CaMV 35S promoter and nos terminator, and a selection marker gene $n p t I I$ with nos promoter and terminator. The $F 3^{\prime} 5^{\prime} H$ gene was isolated from black pansy (Viola $\times$ wittrockiana) and is responsible for converting the dihydroflavonol dihydrokaempferol and/or dihydroquercetin into the dihydroflavonol dihydromyricetin. The activity of the $\mathrm{F}^{\prime} 5^{\prime} \mathrm{H}$ enzyme is essential for the production of blue to purple anthocyanins (Tanaka et al., 2008). The 5AT gene from torenia (Torenia hybrida L.) encodes an enzyme catalyzing the acylation of anthocyanidin 3,5-diglucoside on glycosyl moieties. As a result of acylation, the anthocyanins become more stable, more soluble in water, and their colour becomes more intensely blue (Nakayama et al., 2003). Transgenic callus was induced for plant regeneration and exposed to kanamycin as a selection agent for a period of eight weeks. The developed plants were considered as transgenic, characterized at a molecular level and pigment composition in petals. Molecular analysis of the WKS82/130-41 event revealed that one copy of the $F 3^{\prime} 5^{\prime} H$ gene and two copies of $5 A T$ were inserted into the rose genome. WKS82/130-9-1 plants had one copy of both the $F 3^{\prime} 5^{\prime} H$ and $5 A T$ genes. Transcripts of these genes were detected by Northern blotting in both transgenic lines. They were identified in petals in epidermal L1-derived cells using in situ hybridization. This localization of gene expression was expected, as the anthocyanin biosynthesis pathway is organ-specific in rose. The GM plants contained delphinidin and its derivatives in contrast to the parent plant, which accumulated only cyanidin derivatives. Detailed HPLC analyses confirmed high amounts of delphinidin in the WKS82/1304-1 and WKS82/130-9-1 plants, $55.8 \mu \mathrm{g}$ and 96.0 $\mu \mathrm{g}$ per gram of fresh weight of petals, respectively. Due to the altered anthocyanin biosynthesis and pigment composition, the colour of GM flowers had changed. The colour code of WKS82/130-4-1 was determined as $84 \mathrm{C}$, while that of WKS82/130-9-1 as $76 \mathrm{~A}$, on the RHS Colour Chart. The flower colour was thus much more mauve than the colour of the parent plant. These lines were commercialized as the 'Applause' hybrid tea rose cultivar (APHIS, 2011b; Nakamura, 2010).

Both GM lines were approved for cultivation in Japan in 2008 (JCH, 2008a, 2008b), and first cutflowers were sold in 2009. Only one 'Applause' event (WKS82/130-4-1) has been grown on a small scale in Japan, but a news item dated 2010 indicated that 50,000 roses were sold (Nakamura et al., 2011; Kyodo, 2011; GAIN, 2016d). Australia issued a licence in 2009 for the propagation of parent plants and the growing of plants for cut-flowers of the same 'Applause' event (OGTR, 2009). The licence was surrendered in 2012. Currently, GM rose is produced in Colombia, which issued approval for commercial production, but only in greenhouses and for export of cut-flowers (ICA, 2009). The production is done exclusively at Maxiflores Farms and Flores Luna Nueva farms, where 24,000 plants are grown for cut-flowers exported to the USA, Japan and Australia (Vellekoop, 2017). Import and sale of GM rose in the USA has been allowed since a petition for the determination of non-regulated status of both GM rose events was submitted to APHIS in 2010 and positively reviewed in 2011 (APHIS, 2011a). 'Applause' was available in the USA from 2011 at selected florists, but it was unsuccessful and imports ceased. After improvement, Suntory Ltd. announced in 2017 that 'Applause' was entering the US market again. In January 2018, four thousand 
blue 'Applause' roses and 'Moonshade' carnations were displayed during the $60^{\text {th }}$ anniversary of the Grammy Awards in Madison Square Garden in New York City (Sparks, 2018). The availability of 'Applause' on the market remains limited, and the price of this exclusive flower fluctuates around 40 US\$ per stem.

\section{PERSPECTIVES}

The presented data on GM horticultural plant approval and commercialization show that only selected plants which had passed the regulatory process were later introduced into production and sale. The commercialization remains restricted to selected countries as a consequence of regulatory limits. Certainly, the main GM crop producers in the world have also adopted engineered horticultural plants although with a different attitude. It should be stressed that horticultural plants are genetically modified to possess new characteristics that are mainly either related to virus resistance or improved quality. This is a striking difference from other GM crops widely adopted in the world, i.e., soybean, cotton, maize, canola and sugar beet, which are mainly either herbicide or insect resistant. The purpose of papaya, plum, and squash modification was to ensure high yields in areas severely affected by a viral disease, or pests in the case of eggplant, which otherwise would devastate or significantly diminish production. Other horticultural plants have been modified to satisfy not only farmers' but also customers' demands. The implementation of such plants into production and then the market is thus much more difficult. It requires marketing and communication with the public, raising awareness of the new product's benefits and ensuring all necessary safety measures have been taken. The latter issue is of a particular concern in Europe and Africa. Therefore, field experiments with the virusresistant $\mathrm{C} 5$ plum approved for cultivation in the USA in 2014 have been established and are ongoing in the Czech Republic and Romania (http://gmoinfo. jrc.ec.europa.eu). Trials with the PRSV-resistant papaya have been set up in Brazil, the Philippines and Taiwan.

After 25 years of GM crop adoption, further development of GM technology seems irreversible and will certainly lead to the emergence of new, improved crops that would not be available using conventional methods, or will significantly reduce the time of breeding. In Mexico, efforts are directed towards obtaining new bean varieties resistant to the main soil-borne diseases. Field trials with GM common bean resistant to anthracnose caused by Colletotrichum lindemuthianum, root rot caused by Fusarium lateritium, and damping-off caused by Rhizoctonia solani have been carried out in recent years. Similar projects are underway in Brazil and Korea. Other vegetables, such as cabbage, pepper, broccoli and tomato, are also evaluated in Korea and Taiwan (ISAAA, 2016a). In Japan, the University of Tsukuba and Inplanta Innovations Inc. evaluate miraculin productivity in tomato. Miraculin is a glycoprotein considered as a taste modifier due to its ability to change the perception of sourness to sweetness, and can replace sweeteners in acidic food (Kato et al., 2010).

Advanced field trials with GM horticultural plants are also ongoing in countries resisting the introduction of GM crops into agricultural practice. Among the new perspectives, GMO technology may considerably change the banana industry, which suffers from bacterial and fungal diseases invading tree plantations. Breeding of new resistant cultivars is challenging in this vegetatively reproduced species. Field trials with a GM banana resistant to black Sigatoka (black leaf streak) have been conducted in Kenya and Uganda. Events resistant to Xanthomonas wilt are evaluated in Kenya, to Banana bunchy top virus (BBTV) in Malawi, and to Fusarium wilt in Uganda (ISAAA, 2016a). The engagement of African countries facing severe agricultural problems may reverse the resistance against GMOs and their products in the region. In October 2017, the parliament in Uganda lifted the ban on GM crops and adopted a new biosafety law raising these expectations, but also fears that plantations of GM crops may adversely affect indigenous species. For this reason, the President refused to sign the bill, asking for amendments to ensure additional safety measures and postponing the adoption of GM crops. Recently, Australia approved field trials in 2017-2022 with six GM banana cultivars modified to exhibit resistance to Fusarium wilt (Panama disease), extending previous trials carried out in 2011-2017. The results with the resistance of 'Cavendish', a top cultivar accounting for over $40 \%$ of world's production and most of the international trade, to Fusarium oxysporum $\mathrm{f}$. sp. cubense tropical race 4 devastating plantations in Asia, Africa and Australia, and threatening production and world trade are highly promising. GM 'Cavendish' banana lines with the introduced Caenorhabditis elegans $C e d 9$ anti-apoptosis gene or the Musa acuminata ssp. malaccensis (Ridl.) RGA2 gene, a putative nucleotide-binding and leucine-rich 
repeat (NB-LRR)-type resistance gene, remained immune to TR4, having neither external nor internal symptoms, in contrast to a non-GM control with $67-100 \%$ plants infected or dead throughout a three-year field trial (Dale et al., 2017). Australia and Uganda have also approved trials with a GM banana modified toward enhanced nutrition, i.e., with increased levels of pro-vitamin $\mathrm{A}$ and iron (OGTR, 2017). The latter may significantly help to mitigate the severe problem of vitamin A and iron deficiency in Africa.

Advanced work has also been carried out with chrysanthemums (Chrysanthemum morifolium Ramat.), which are the second most popular cut flowers. Research commenced by groups at Florigene and Suntory, in cooperation with the Institute of Floricultural Science (NIFS), the National Agriculture and Food Research Organization (NARO) in Japan, has aimed at the development of plants with bluish flowers, like in carnation and rose. To alter anthocyanin biosynthesis, a Canterbury bells (Campanula medium L.) F3'5'H gene was expressed under the control of a petal-specific promoter from the chrysanthemum flavanone 3-hydroxylase gene. The amount of delphinidin in petals increased significantly and reached $95 \%$ of total anthocyanins. In an alternative approach, the redirection of the anthocyanin biosynthetic pathway to delphinidin was obtained by the expression of a pansy $F 3^{\prime} 5^{\prime} H$ gene under the control of a rose chs promoter or by down-regulation of the biosynthesis of cyanidin-based pigments. In both cases, the increase of delphinidin was achieved, up to $40 \%$ and $80 \%$, respectively (Brugliera et al., 2013; Noda et al., 2013; Noda and Tanaka, 2013). The blue chrysanthemums were approved for experimental plantings in greenhouse conditions in Colombia in 2009, and then Suntory Ltd. was granted permission for commercial in-greenhouse production of cutflowers for export only (ICA, 2012). Production of bluish chrysanthemum flowers is therefore possible under the same conditions as the already ongoing production of carnation and rose. However, there is no official information whether the production has commenced, as the bluish chrysanthemum colour was unstable. A recent report from NARO and Suntory research groups foreshadows further advances in flower breeding. Noda et al. (2017) have engineered chrysanthemum to possess a butterfly pea (Clitoria ternatea L.) uridine diphosphate (UDP)-glucose:anthocyanin $3^{\prime}, 5^{\prime}$-O $O$-glucosyltransferase (anthocyanin UGT) gene and a Canterbury bells $F 3^{\prime} 5^{\prime} H$ gene. Their expression led to a two-step modification of the structure of anthocyanins, ensuring a stable and true-blue colour of petals not achieved in other GM ornamental plants so far.

A critical issue for the commercialization of genetically enhanced horticultural plants will be the policy of regulating products developed by using so-called new plant-breeding technologies (NBTs). Several NBTs leading to genome editing open new perspectives of precise and targeted gene modification (Fichtner et al., 2014). These new techniques allow site-directed mutagenesis, either point mutation, short indel, or larger fragment deletion, substitution and insertion without leaving signs of exogenous DNA delivery (Songstad et al., 2017). Moreover, the newest technique relies on the delivery of an unstable RNA-protein complex instead of DNA to the host cell (Svitashev et al., 2016). Such a complex is responsible for precise modification at the target site, and after the DNA change, the complex is degraded. The resulting organism with induced mutation using NBTs may be essentially not distinguishable from an analogous organism with a spontaneous mutation. The development of NBTs provokes important questions whether these techniques result in GMOs or not. The answer is critical for regulatory agencies: how to proceed with new applications and how stringent regulations should be applied for authorization (Wolt et al., 2016). Some countries have already issued statements liberating commercialization of organisms with a genome edited using NBTs, and such new products have become a reality. The first genome-edited crop introduced into the market was canola tolerant to sulfonylurea herbicide, developed using an oligonucleotide-directed nuclease (ODN) responsible for the induction of a point mutation in the acetolactate synthase gene (Gocal, 2015). This genetically engineered SU Canola ${ }^{\mathrm{TM}}$ was considered as a non-GM event and approved in Canada in 2013 , and then commercialized after registration of a hybrid variety in 2017 (HC, 2013). In 2016, the USDA also issued the first opinion that did not regard a non-browning mushroom, developed by the CRISPR gene-editing technology, as a regulated article, accepting the developer's statement that this engineered mushroom contained a small gene deletion and no foreign DNA (APHIS, 2016b). The fast progress in NBTs and the need for a less stringent and more flexible regulatory system, still ensuring safety, enforce legislation revisit and update not to hinder progress affecting industry and scientific research. In the USA, new rules were proposed by 
APHIS (APHIS, 2017b); however, the proposal was withdrawn after receiving contradictory comments (APHIS, 2017c). Recently, the US Secretary of Agriculture has issued a statement that "USDA does not regulate or have any plans to regulate plants that could otherwise have been developed through traditional breeding techniques as long as they are not plant pests or developed using plant pests. This includes a set of new techniques that are increasingly being used by plant breeders to produce new plant varieties that are indistinguishable from those developed through traditional breeding methods. The newest of these methods, such as genome editing, expand traditional plant breeding tools because they can introduce new plant traits more quickly and precisely, potentially saving years or even decades in bringing needed new varieties to farmers." (USDA Press, 2018). The statement clarifies that at least some NBT-delivered plants shall not be considered as regulated articles, thus announcing liberation of their commercialization. Some countries, e.g., Canada, Australia, India, and Argentina, have expressed a policy towards accepting NBTs (Schuttelaar, 2015), while the EU is still facing a pending revision of its stringent regulatory process established based on an almost 30 -year-old definition of GMO, and not adequate to current scientific evidence (Sprink et al., 2016). However, a recent opinion of the Advocate General of the Court of Justice of the EU (Case C-528/16) clarifying the interpretation of the operating Directive 2001/18/EC on the deliberate release into the environment of GMOs is a step towards exemption of organisms obtained by mutagenesis in principle (thus also those obtained using some NBTs) from the obligations in the said Directive (European Court, 2018). The Court of Justice's decision expected in 2018 may be critical for overcoming uncertainty related to the interpretation of the EU legislation and for the clarification of the legal status of organisms, including plants, developed using NBTs.

\section{FUNDING}

This review was completed within the University's statutory research task financed by the Ministry of Science and Higher Education of the Republic of Poland.

\section{AUTHOR CONTRIBUTIONS}

A.L. - wrote the vegetable plant section; M.K-Ch. - wrote the ornamental plant section; R.B. - wrote the fruit trees section and the general sections. All of the authors commented on the whole manuscript.

\section{CONFLICT OF INTEREST}

Authors declare no conflict of interest.

\section{REFERENCES}

ABCA, 2012. GM carnations in Australia: a resource guide. http://www.abca.com.au/wp-content/ uploads/2012/09/ABCA_Resource_Guide_2_v2.pdf. Accessed 18 January 2018.

ACBIO, 2013. GM industry called to account: ISAAA's report mischievous and erroneous. African Centre for Biosafety. https://acbio.org.za/gm-industry-called-toaccount-isaaas-report-mischievous-and-erroneous. Accessed 1 October 2017.

AFCD, 2015. Review of the exemption of genetically modified papayas in Hong Kong. Discussion Paper GMO 04/2015. Agriculture, Fisheries and Conservation Department, Hong Kong. https://www. afcd.gov.hk/english/conservation/con_gmo/gmo exp/files/Discussion_Paper_GMO_04_2015.pdf.pdf. Accessed 30 September 2017.

AFCD, 2017. Report on the Survey of Genetically Modified Organisms in Hong Kong. Discussion Paper GMO 02/2017. Agriculture, Fisheries and Conservation Department, Hong Kong. https://www. afcd.gov.hk/english/conservation/con_gmo/gmo exp/files/Discussion_Paper_GMO_04_2015.pdf.pdf. Accessed 23 March 2018.

Alonso-Prados J.L., Fraile A., Garcia-Arenal F., 1997. Impact of Cucumber mosaic virus and Watermelon mosaic virus-2 infection on melon production in central Spain. J. Plant Pathol. 79(2), 131-134.

AP, 2016. Hawaii counties can't regulate GMOs and pesticides according to new ruling. The Associated Press November. 19 2016. http:/fortune. com/2016/11/19/hawaii-gmo-pesticide-regulation. Accessed 1 October 2017.

APHIS, 1992a. Petition for determination: Flavr Savr ${ }^{\mathrm{TM}}$ Tomato as non-regulated under CFR340 1992. USDA APHIS. https://www.aphis.usda.gov/brs/ aphisdocs/92_19601p.pdf. Accessed 1 March 2018.

APHIS, 1992b. Response to Calgene petition for determination of regulatory status. USDA APHIS. https://www.aphis.usda.gov/brs/ aphisdocs2/92_19601p_com.pdf. Accessed 1 March 2018.

APHIS, 1992c. Petition for determination regulatory status of Cucurbita pepo L. cultivar YC77E ZW20. USDA APHIS Petition No. 92-204-01p. https:// www.aphis.usda.gov/brs/aphisdocs/92_20401p.pdf. Accessed 17 March 2018.

APHIS, 1994a. Petition for release from regulation for modified lines B, Da, F derived from T7 varieties of processing tomato. USDA APHIS. https://www.aphis. 
usda.gov/brs/aphisdocs/94_29001p.pdf. Accessed 1 March 2018.

APHIS, 1994b. Addition of one genetically engineered tomato line to determination of non-regulated status for Calgene, Inc. USDA APHIS. https://www.aphis. usda.gov/brs/aphisdocs2/94_22701p_com.pdf. Accessed 1 March 2018.

APHIS, 1994c. Determination of nonregulated status for additional Calgene, Inc., genetically engineered FLAVR SAVR ${ }^{\mathrm{TM}}$ tomato lines. USDA APHIS Docket No. 94-125-1. https://www.aphis.usda.gov/brs/ aphisdocs2/94_23001p_com.pdf. Accessed 1 March 2018.

APHIS, 1994d. Petition for determination of nonregulated status: delayed-ripening tomato line 1345-4. USDA APHIS. https://www.aphis.usda.gov/brs/ aphisdocs/94_22801p.pdf. Accessed 5 March 2018.

APHIS, 1995a. Petition for determination of nonregulated status for additional Calgene, Inc., genetically engineered FLAVR SAVR ${ }^{\mathrm{TM}}$ tomato lines. USDA APHIS. https://www.aphis.usda.gov/brs/ aphisdocs2/95_03001p_com.pdf. Accessed 1 March 2018.

APHIS, 1995b. Addition of two genetically engineered tomato lines to determination of nonregulated status for Calgene, Inc. USDA APHIS Docket No. 95-068-1. https://www.aphis.usda.gov/brs/ aphisdocs2/95_17901p_com.pdf. Accessed 1 March 2018.

APHIS, 1995c. Availability of determination of nonregulated status for genetically engineered tomato lines. USDA APHIS Docket No. 95-016-2. Federal Register 60(121), 32650. https://www.aphis.usda. gov/brs/aphisdocs2/94_29001p_com.pdf. Accessed 1 March 2018.

APHIS, 1995d. Petition for determination of nonregulated status: cherry tomatoes with S-adenosylmethionine hydrolase gene. USDA APHIS. https://www.aphis. usda.gov/brs/aphisdocs/95_32401p.pdf. Accessed 5 March 2018.

APHIS, 1995e. Petition for determination of nonregulated status: tomatoes with delayed ripening gene. USDA APHIS. https://www.aphis.usda.gov/brs/ aphisdocs/95_05301p.pdf 8338. Accessed 5 March 2018.

APHIS, 1995f. Availability of determination of nonregulated status for genetically engineered tomato line of Monsanto company. USDA APHIS Docket No. 95-042-1. Federal Register 60(195), 52642. https:// www.govinfo.gov/content/pkg/FR-1995-10-10/pdf/ FR-1995-10-10.pdf. Accessed 6 March 2018.

APHIS, 1995g. Response to DNA Plant Technology Corporation petition for determination of nonregulated status for tomato line 1345-4. USDA APHIS. https:// www.aphis.usda.gov/brs/aphisdocs2/94_22801p_ com.pdf. Accessed 6 March 2018.

APHIS, 1995h. Petition for determination of nonregulated status: squash containing the coat protein genes from
Cucumber Mosaic Virus (CMV), Watermelon Mosaic Virus 2 (WMV 2), and Zucchini Yellow Mosaic Virus (ZYMV). USDA APHIS Petition No. 95-352-01p. https://www.aphis.usda.gov/brs/aphisdocs/95_35201p. pdf. Accessed 17 March 2018.

APHIS, 1995i. Availability of determination of nonregulated status for virus resistant squash. USDA APHIS Docket No. 92-127-4. Federal Register 59(238), 64187. https://www.aphis.usda.gov/brs/ aphisdocs2/92_20401p_com.pdf. Accessed 17 March 2018.

APHIS, 1996a. Calgene, Inc. Addition of one genetically engineered tomato line to determination of nonregulated status. USDA APHIS Docket No. 96-080-1. https://www.aphis.usda.gov/brs/ aphisdocs2/96_24801p_com.pdf. Accessed 1 March 2018.

APHIS, 1996b. Agritope, Inc. Availability of determination of nonregulated status for cherry tomato line genetically engineered for modified fruit ripening. USDA APHIS Docket No. 95-097-2. Federal Register 61(70), 15919. https://www.aphis.usda. gov/brs/aphisdocs2/95_32401p_com.pdf. Accessed 5 March 2018.

APHIS, 1996c. Asgrow Seed Co. Availability of determination of nonregulated status for squash line genetically engineered for virus resistance. USDA APHIS Docket No. 96-002-2. Federal Register 61(125), 33484. https://www.aphis.usda.gov/brs/ aphisdocs2/95_35201p_com.pdf. Accessed 17 March 2018.

APHIS, 1996d. Petition for determination of regulatory status: transgenic papaya lines 55-1 and 63-1 and their derivatives. USDA APHIS Docket No. 96-024-1, Petition No. 96-051-01p. http://www.aphis.usda.gov/ brs/aphisdocs/96_05101p.pdf. Accessed 26 March 2018.

APHIS, 1996e. Corenell University and University of Hawaii; Availability of determination of nonregulated status for papaya lines genetically engineered for virus resistance. USDA APHIS Docket No. 96024-2. Federal Register 61(180), 48663. http://www. aphis.usda.gov/brs/aphisdocs2/96_05101p_com.pdf. Accessed 30 September 2017.

APHIS, 1997a. Petition for determination of nonregulated status for insect resistant tomato line 5345. USDA APHIS. https://www.aphis.usda.gov/brs/ aphisdocs/97_28701p.pdf. Accessed 7 April 2018.

APHIS, 1997b. Monsanto Co. Availability of determination of nonregulated status for tomato genetically engineered for insect resistance. USDA APHIS Docket No. 97-114-2. https://www.aphis.usda. gov/brs/aphisdocs2/97_28701p_com.pdf. Accessed 7 April 2018.

APHIS, 1997c. Petition for determination of nonregulated status for radicchio rosso lines with male sterility (SEED LINK ${ }^{\mathrm{TM}}$ ). USDA APHIS. https://www.aphis. 
usda.gov/brs/aphisdocs/97 14801p.pdf. Accessed 8 March 2018.

APHIS, 1997d. Bejo Zaden BV. Availability of determination of nonregulated status for genetically engineered radicchio rosso. USDA APHIS Docket No. 97-067-2. https://www.aphis.usda.gov/brs/ aphisdocs2/97_14801p_com.pdf. Accessed 8 March 2018.

APHIS, 1999. Agritope, Inc. Availability of environmental assessment for determination of nonregulated status. USDA APHIS Docket No. 99-003-2. Federal Register 64(206), 57625. http://en.biosafetyscanner.org/pdf/ev enti/148_59700d5e6efd9b2f8c06fa4f63568f8f.pdf. Accessed 10 March 2018.

APHIS, 2007a. Approval of USDA-ARS request (04-26401P) seeking a determination of non-regulated status for C5 plum resistant to Plum Pox Virus. Finding of no significant impact and decision notice. USDA APHIS Combined documents. http://www.aphis.usda. gov/brs/aphisdocs2/04_26401p_com.pdf. Accessed 27 March 2018.

APHIS, 2007b. University of Florida. Determination of nonregulated status for plum genetically engineered for resistance to Plum pox virus. USDA APHIS Docket No. APHIS-2008-0054. Federal Register 72(134), 38556. http://www.aphis.usda.gov/brs/ fedregister/BRS_20090901.pdf. Accessed 27 March 2018.

APHIS, 2008. Petition for nonregulated status for the X17-2 line of papaya: a Papaya ringspot virus - resistant papaya. USDA APHIS. http://www.aphis. usda.gov/brs/aphisdocs/04_33701p.pdf. Accessed 30 September 2017.

APHIS, 2009a. Finding of no significant impact. Petition for nonregulated status for University of Florida X172 papaya. USDA APHIS. http://www.aphis.usda. gov/brs/aphisdocs2/04_33701p_com.pdf. Accessed 30 September 2017.

APHIS, 2009b. University of Florida. Determination of nonregulated status for papaya genetically engineered for resistance to the Papaya ringspot virus. USDA APHIS Docket No. APHIS-2008-0054. Federal Register 74(168), 45163. http://www.aphis.usda.gov/ brs/fedregister/BRS_20090901.pdf. Accessed 30 September 2017.

APHIS, 2011a. Determination of nonregulated status for altered color roses. USDA APHIS Docket No. APHIS-2010-0040. Federal Register 76(189), 60447. https://www.aphis.usda.gov/brs/fedregister/ BRS_20110929a.pdf. Accessed 18 January 2018.

APHIS, 2011b. Petition (08-315-01p) for a determination of nonregulated status for Rosa $x$ hybrida varieties IFD-524Ø1-4 and IFD-529Ø1-9 - ADDENDUM 1. USDA APHIS. https://www.aphis.usda.gov/brs/ aphisdocs/08_31501p.pdf. Accessed 18 January 2018.

APHIS, 2012. Petition for determination of nonregulated status: Arctic ${ }^{\mathrm{TM}}$ apple (Malus $x$ domestica) events GD743 and GS784. USDA APHIS Docket No.
APHIS-2012-0025, petition No. 10-161-01p. http:// www.aphis.usda.gov/brs/aphisdocs/10_16101p.pdf. Accessed 24 September 2017.

APHIS, 2014. Determination of nonregulated status for Okanagan Specialty Fruits' GD743 and GS784 apples. USDA APHIS Docket No. APHIS-2012-0025. http:// www.aphis.usda.gov/brs/aphisdocs/10_16101p_det. pdf. Accessed 24 September 2017.

APHIS, 2015. Okanagan Specialty Fruits, Inc; Determination of nonregulated status of apples genetically engineered to resist browning. USDA APHIS Docket No. APHIS-2012-0025. Federal Register 80(32), 8589. https://www.regulations.gov/ document?D=APHIS-2012-0025-6945. Accessed 24 September 2017.

APHIS, 2016a. National environmental policy act decision and finding of no significant impact: Request for extension of determination of non-regulated status for non-browning Arctic ${ }^{\circledR}$ Fuji apple (16-004-01p). USDA APHIS Docket No. APHIS-2016-0043. https:// www.aphis.usda.gov/brs/aphisdocs/16_00401p_fonsi. pdf. Accessed 24 September 2017.

APHIS, 2016b. Response letter to the request for confirmation that transgene-free, CRISPR-edited mushroom is not a regulated article. USDA APHIS. https://www.aphis.usda.gov/biotechnology/ downloads/reg_loi/15-321-01_air_response_signed. pdf. Accessed 4 April 2018.

APHIS, 2017a. BRS list of varieties requiring import authorization. Updated 3 October 2017. USDA APHIS. https://www.aphis.usda.gov/biotechnology/ downloads/petunia_varieties.pdf. Accessed 20 April 2018.

APHIS, 2017b. Proposed rule. Importation, interstate movement, and environmental release of certain genetically engineered organisms. USDA APHIS Docket No. APHIS-2015-0057. Federal Register, 2017. 82(214), 7008. https://www.aphis.usda.gov/brs/ fedregister/BRS_20171107.pdf. Accessed 4 April 2018.

APHIS, 2017c. Proposed rule; withdrawal. Importation, interstate movement, and environmental release of certain genetically engineered organisms. USDA APHIS Docket No. APHIS-2015-0057. Federal Register, 2017. 82(12),51582. https://www.aphis.usda. gov/brs/fedregister/BRS_20170119.pdf. Accessed 26 March 2018.

Aragao F.J.L., Faria J.C., 2009. First transgenic geminivirus-resistant plant in the field. Nat. Biotechnol. 27(12), 1086-1088.

Aragao F.J.L., Nogueira E.O.P.L., Tinoco M.L.P., FARIA J.C., 2013. Molecular characterization of the first commercial transgenic common bean immune to the Bean golden mosaic virus. J. Biotechnol. 166(12), 42-50.

Armstrong J., Lane W.D., 2011. Genetically modified reduced-browning fruit-producing plant and produced fruit thereof, and method of obtaining such. US patent 
$8,563,805$, application by Okanagan Specialty Fruits Inc., filled 26.02.2009, published 6.01.2011. https:// www.lens.org/lens/patent/US_8563805_B2. Accessed 19 June 2018.

BAKUM J., 2015. Director of General of BARI remarks about BT brinjal. https://bteggplant.cornell.edu/ content/blog/blog-tags/1. Accessed 8 April 2018.

Bashandy H., TeEri T. H., 2017. Genetically engineered orange petunias on the market. Planta 246(2), 277280.

Basso M.F., Lima J.A.A., Deguchi M., Galdeano D.M., Fernandes P.M.B., 2016. Papaya viral diseases: recent advances and perspectives. In: Urbano K.V. (ed.), Advances in Genetics Research 16, 135-150.

BCH, 2012a. Modified organism CGN-89564-2 - FLAVR SAVR $^{\mathrm{TM}}$ tomato. Biosafety Clearing-House. http://bch. cbd.int/database/record.shtml?documentid=14867. Accessed 1 March 2018.

$\mathrm{BCH}, 2012 \mathrm{~b}$. Modified organism cantaloupe A (delayed ripening). Biosafety Clearing-House. http://bch. cbd.int/database/record. shtml?documentid=15388. Accessed 10 March 2018.

$\mathrm{BCH}, 2012 \mathrm{c}$. Modified organism Huafan No 1. Biosafety Clearing-House. http://www.isaaa.org/ gmapprovaldatabase/event/default.asp?EventID=186. Accessed 2 June 2018.

BCH, 2012d. Modified organism Da Dong No 9. Biosafety Clearing-House. http://www.isaaa.org/ gmapprovaldatabase/event/default.asp?EventID=187. Accessed 2 June 2018.

BCH, 2012e. Modified organism PK-TM8805R (8805R). Biosafety Clearing-House. http://www.isaaa.org/ gmapprovaldatabase/event/default.asp?EventID=188. Accessed 2 June 2018.

$\mathrm{BCH}$, 2013a. Modified organism SYN0000B-6 - Tomato modified for delayed softening, Biosafety Clearing-House. http://bch.cbd.int/database/record. shtml?documentid=15405. Accessed 5 March 2018.

$\mathrm{BCH}$, 2013b. Modified organism SYN-000DA-9 - Tomato modified for delayed softening. Biosafety Clearing-House. http://bch.cbd.int/database/record. shtml?documentid=15406. Accessed 2 March 2018.

$\mathrm{BCH}, 2013 \mathrm{c}$. Modified organism SYN-0000F-1 - Tomato modified for delayed softening. Biosafety Clearing-House. http://bch.cbd.int/database/record. shtml?documentid=15407. Accessed 2 March 2018.

$\mathrm{BCH}, 2014 \mathrm{a}$. Modified organism tomato modified for delayed ripening 35-1-N. Biosafety ClearingHouse. http://bch.cbd.int/database/record. shtml?documentid=15419. Accessed 5 March 2018.

$\mathrm{BCH}, 2014 \mathrm{~b}$. Modified organism tomato modified for delayed ripening 1345-4. Biosafety ClearingHouse. http://bch.cbd.int/database/record. shtml?documentid=15395. Accessed 5 March 2018.

BCH, 2014c. CGN-89322-3 - Delayed-ripening tomato. Biosafety Clearing-House. http://bch.cbd.int/database/ record.shtml?documentid=14781. Accessed 5 March 2018.
$\mathrm{BCH}, 2014 \mathrm{~d}$. Notification of a transboundary movement of an LMO carried out in contravention of domestic measures to implement the Protocol (Article 25.3). Biosafety Clearing-House Japan country communication. http://bch.cbd.int/database/ attachment/?id=14684. Accessed 30 September 2017.

$\mathrm{BCH}, 2018 \mathrm{a}$. Convention on Biological Diversity. Country's decision or any other communication. Biosafety Cleaning-House. http://bch.cbd.int/ database/record.shtml?documentid=111644. Accessed 17 May 2017.

BCH, 2018b. Convention on Biological Diversity. Risk assessment. Biosafety Cleaning-House. http://bch. cbd.int $/$ database/record.shtml?documentid=111643. Accessed 17 May 2017.

Bedbrook J.R., Howie W.J., Dunsmuir P., Lee K.Y., JoE L.K., 1997. Delayed ripening tomato plants. International Patent WO/1997/001952, application by DNA Plant Technology Corp., filled 28.06.1996, published 23.01.1997. https://patentscope.wipo.int/ search/en/detail.jsf?docId=WO1997001952. Accessed 19 June 2018.

Biology discussion, 2016. Bt-brinjal: Production and its development; India. http://www.biologydiscussion. com/vegetable-breeding/bt-brinjal-production-andits-development-india/68749. Accessed 4 March 2018.

BiosafetyScanner, 2018. Scheda evento $8805 \mathrm{R}$ e metodi di analisi. Fondazione Diritti Genetici. http://www. biosafetyscanner.org/schedaevento.php?radioeve $n$ ti $=$ radiobutton $\&$ evento $=242 \&$ evento $1=\#$ tabs $-1 \mathrm{a}$. Accessed 2 June 2018.

Bommineni V.R., Mathews H., Clendennen S.K., Wagoner W., Dewey V., Kellogg J., et Al., 2000. Genetic engineering of fruits and vegetables with the ethylene control gene encoding S-adenosylmethionine hydrolase (SAMase) In: Plant Genetic Engineering: Towards the Third Millennium. A.D. Arenciba (ed.), Elsevier Science BV, 206-214.

Bonfim K., Faria J.C., Nogueira E.O.P.L., Mendes E.A., Aragao F.J.L., 2007. RNAi-mediated resistance to Bean golden mosaic virus in genetically engineered common bean (Phaseolus vulgaris). Mol. Plant Microbe Interact. 20(6), 717-726.

Brady C., MacAlpine G., McGlasson W.B., Ueda Y., 1982. Polygalacturonase in tomato fruit and the induction of ripening. Aust. J. Plant Physiol. 9, 171178.

BRUEning G, Lyons J., 2000. The case of the FLAVR SAVR tomato. California Agriculture 54(4), 6-7.

Brugliera F., TA, G.Q., Tems U., Kalc G., Mouradova E., Price K., ET Al., 2013. Violet/blue chrysanthemums - metabolic engineering of the anthocyanin biosynthetic pathway results in novel petal colors. Plant Cell Physiol. 54(10), 1696-1710.

Cambra M., Capote N., Myrta A., Llá́cer G., 2006. Plum pox virus and the estimated costs associated with sharka disease. OEPP/EPPO Bull. 36(2), 202204. 
Carillo C.A., 2017. GM eggplant completes latest field trials. http://bworldonline.com/gm-eggplantcompletes-latest-field-trials/. Accessed 8 April 2018.

CERA, 1998. UK Competent Authority: Initial assessment report. Application number 98/UK/1. Report on the safety assessment of processed products from Zeneca's genetically modified (GM) tomatoes derived from line TGT7F. http://cera-gmc.org/docs/ decdocs/tgt7f acnfp.pdf. Accessed 7 April 2018.

CFIA, 2015. Decision document DD2015-110: Determination of the Safety of Okanagan Specialty Fruits Inc.'s apple (Malus domestica Borkh) events GD743 and GS784. CFIA. http://inspection.gc.ca/ plants/plants-with-novel-traits/approved-underreview/decision-documents/dd2015-110/eng/1498237 204300/1498237333410. Accessed 24 September 2017.

Chen Z., Yang R., 1996. Method for cultivating tomato with function of anti virus of mosaic of cucumber by gene engineering. China patent CN 1054160, application by Beijing University, filled 4.07.1995, published 7.02.1996. https://patentscope.wipo.int/ search/en/detail.jsf?docId=CN82309046\&redirected ID=true. Accessed 19 June 2018.

Choudhary B., Gaur K., 2009. The development and regulation of $\mathrm{Bt}$ brinjal in India (Eggplant/ Aubergine). ISAAA Brief No.38. ISAAA: Ithaca, NY.

COFEPRIS, 2018. Lista de evaluacion de inocuidad caso por caso de los organismos geneticamente modificados (OGMs). http://www.cofepris.gob.mx/ AZ/Paginas/OGMS/Lista.aspx. Accessed 12 March 2018.

COGEM, 2007. Advices import of genetically modified carnation 'Moonaqua'. CGM/070206-02. https://www. cogem.net/showdownload.cfm?objectId=FFFE71E71517-64D9-CC1798C061035456\&objectType=mark. apps.cogem.contentobjects.publication.download.pdf. Accessed 18 January 2018.

COGEM, 2017. Unauthorised GM garden petunia varieties with orange flowers. COGEM advice CGM/17052204. https://www.cogem.net/showdownload. cfm?objectId=3E808913-D0A9-773D-9CBDA6C4 C03308B4\&objectType $=$ mark.hive.contentobjects. download.pdf. Accessed 20 April 2018.

CTNBio, 2011. Commercial release of genetically modified beans. 3024/2011. http://ctnbio. mcti.gov.br/documents/566529/686051/ Technical+Opinion+No.+3024-2011+-+Com mercial + Release + of + genetically + modified $+b$ ean + resistant + to + Bean + Golden + Mosaic + Vir us+-Bean+golden+mosaic +virus +-+BGMV+event+Embrapa+5.1+-+Case+No.+01200.0051612010-86/30b55a23-ed57-4e13-8232-bd59571252cc;j sessionid=17C34F55F92DF00F2D7CABD3A9D9E7 BF.rima?version=1.0. Accessed 18 March 2018.

Dahmani-Mardas F., Troadec C., Boualem A., LévêQue S., Alsadon A.A., Aldoss A.A., Bendahmane A., 2010. Engineering melon plants with improved fruit shelf life using the TILLING approach. PLoS ONE, 5(12), e15776.

Dai S., Zheng P., Marmey P., Zhang S., Tian W., Chen S., ET AL., 2001. Comparative analysis of transgenic rice plants obtained by Agrobacterium-mediated transformation and particle bombardment. Mol. Breed. 7(1), 25-33.

Dale J., James A., Paul J.-Y., Khanna H., Smith M., Peraza-Echeverria S., et al., 2017. Transgenic Cavendish bananas with resistance to Fusarium wilt tropical race 4. Nature Commun. 8(1), 1496.

Dellanay X., LaVallee B.J., Proksch R.K., Fuchs R.L., Sims S.R., GreenPlate J.T., ET AL., 1989. Field performance of transgenic tomato plants expressing the Bacillus thuringiensis var. kurstaki insect control protein. Nat. Biotechnol. 7, 1265-1269.

EC, 1996. 96/424/EC: Commission Decision of 20 May 1996 concerning the placing on the market of genetically modified male sterile chicory (Cichorium intybus L.) with partial tolerance to the herbicide glufosinate ammonium pursuant to Council Directive 90/220/EEC. https://eur-lex.europa.eu/legal-content/ EN/TXT/?uri=CELEX\%3A31996D0424. Accessed 8 March 2018.

EC, 1999. Opinion on a request for consent to place on the market a tomato fruit genetically modified to down-regulate the production of polygalacturonase (PG), and solely intended for processing. SCF/CS.NF/ TOM/6 REV 4 final. https://ec.europa.eu/food/sites/ food/files/safety/docs/sci-com_scf_out42_en.pdf. Accessed 23 March 2018.

EC, 2007. 2007/364/EC, Commission decision of 23 May 2007 concerning the placing on the market, in accordance with Directive 2001/18/EC of the European Parliament and of the Council, of a carnation (Dianthus caryophyllus L., line 123.2.38) genetically modified for flower colour. Document C(2007)2120. Official Journal of the European Union L 138, 50-52. http://eur-lex.europa.eu/LexUriServ/ LexUriServ.do?uri=OJ:L:2007:138:0050:0052:EN:P DF. Accessed 18 December 2017.

EC, 2009. 2009/244/EC, Commission decision of 16 March 2009 concerning the placing on the market, in accordance with Directive 2001/18/EC of the European Parliament and of the Council, of a carnation (Dianthus caryophyllus L., line 123.8.12) genetically modified for flower colour. Document C(2009)1673. Official Journal of the European Union L 72, 18-20. http://eur-lex.europa.eu/legal-content/ EN/TXT/PDF/?uri=CELEX:32009D0244\&rid=1. Accessed 18 December 2017.

EC, 2015a. 2015/692, Commission implementing decision (EU) $2015 / 692$ of 24 April 2015 concerning the placing on the market, in accordance with Directive 2001/18/EC of the European Parliament and of the Council, of a carnation (Dianthus caryophyllus L., line 25958) genetically modified for flower colour. Document C(2015)2765. Official Journal of the 
European Union L 112:44-47. http://eur-lex.europa. eu/legal-content/EN/TXT/PDF/?uri=CELEX:32015 D0692\&from=EN. Accessed 18 December 2017.

EC, 2015b. 2015/694, Commission Implementing Decision (EU) 2015/694 of 24 April 2015 concerning the placing on the market, in accordance with Directive 2001/18/EC of the European Parliament and of the Council, of a carnation (Dianthus caryophyllus L., line 26407) genetically modified for flower colour. Document C(2015)2768. Official Journal of the European Union L 112:52-55. http://eur-lex.europa.eu/ legal-content/EN/TXT/PDF/?uri=CELEX:32015D06 94\&from=EN. Accessed 18 December 2017.

EC, 2016. 2016/2050, Commission Implementing Decision (EU) 2016/2050 of 22 November 2016 as regards the placing on the market of a genetically modified carnation (Dianthus caryophyllus L., line SHD-27531-4). Document C(2016)7443. Official Journal of the European Union L 318:13-16. https:// eur-lex.europa.eu/legal-content/EN/TXT/PDF/? uri=CELEX:32016D2050\&from=EN. Accessed 18 December 2017.

Elderidge S., 2003 Food biotechnology: Current issues and perspectives. Nova Science USA, 11.

EMBRAPA, 2016. Bean cultivar BRS FC 401 RMD resistant to the Golden mosaic virus official statement. https:// www.embrapa.br/en/esclarecimentos-oficiais/-/asset publisher/TMQZKuljxu5K/content/tema-cultivar-defeijao-resistente-ao-mosaico-dourado-brs-fc401-rmd. Accessed 15 March 2018.

EPA, 2010. Coat protein gene of Plum pox virus. Biopesticides registration action document, PC Code: 006354. https://www3.epa.gov/pesticides/ chem search/reg actions/registration/decision PC006354_7-May-10.pdf. Accessed 24 September 2017.

EPA, 2014. Notice of pesticide registration C5 HoneySweet Plum No. 11312-8. https://www3.epa. gov/pesticides/chem_search/ppls/011312-0000820140930.pdf. Accessed 24 September 2017.

EPA, 2016. Notice of pesticide registration X17-2 Papaya No. 84427-1. https://www3.epa.gov/pesticides/chem search/ppls/084427-00001-20160112.pdf. Accessed 30 September 2017.

European Court, 2018. Advocate General's Opinion of 18 January 2018, Request for a preliminary ruling from the Council of State, France (C-528/16, ECLI:EU:C:2018:20).

Evans E.A., Ballen F.H., Crane J.H., 2015. An overview of US papaya production, trade, and consumption. University of Florida IFAS Extension, FE914. http:// edis.ifas.ufl.edu/fe914. Accessed 30 September 2017.

FDA, 1992. Statement of policy - Foods derived from new plant varieties. Federal Register 57. Guidance to industry for food derived from new plant varieties. https://www.fda.gov/Food/GuidanceRegulation/ GuidanceDocumentsRegulatoryInformation/ Biotechnology/ucm096095.htm. Accessed 3 March 2018.
FDA, 1994. Agency Response Letter Re: FMF 526 and Docket No. 91A-0330. CFSAN/Office of Premarket Approval. http://wayback.archive-it. org/7993/20180124124721/https://www.fda.gov/ Food/IngredientsPackagingLabeling/GEPlants/ Submissions/ucm225027.htm. Accessed 3 March 2018.

FDA, 1995a. Biotechnology Consultation Agency Response Letter BNF No. 000003. http://wayback. archive-it.org/7993/20171031095124/https://www.fda. gov/Food/IngredientsPackagingLabeling/GEPlants/ Submissions/ucm161127.htm. Accessed 15 March 2018

FDA, 1995b. Biotechnology Consultation Agency Response Letter BNF No.000002. http://wayback. archive-it.org/7993/20171031095145/https:/www.fda. gov/Food/IngredientsPackagingLabeling/GEPlants/ Submissions/ucm 161128.htm. Accessed 5 March 2018.

FDA, 1995c. Biotechnology Consultation Agency Response Letter BNF No. 000007. http://wayback. archive-it.org/7993/20171031095507/https://www.fda. gov/Food/IngredientsPackagingLabeling/GEPlants/ Submissions/ucm161123.htm. Accessed 6 March 2018.

FDA, 1995d. Biotechnology Consultation Agency Response Letter BNF No. 000006. http://wayback. archive-it.org/7993/20171031095519/https:/www.fda. gov/Food/IngredientsPackagingLabeling/GEPlants/ Submissions/ucm161124.htm. Accessed 17 March 2018

FDA, 1996. Biotechnology Consultation Agency Response Letter BNF No. 000014. http://wayback. archive-it.org/7993/20171031095102/https:/www.fda. gov/Food/IngredientsPackagingLabeling/GEPlants/ Submissions/ucm161114.htm. Accessed 15 March 2018.

FDA, 1997a. Biotechnology Consultation Agency Response Letter BNF 000043. http://wayback. archive-it.org/7993/20171031093739/https:/www.fda. gov/Food/IngredientsPackagingLabeling/GEPlants/ Submissions/ucm161103.htm. Accessed 17 March 2018.

FDA, 1997b. Biotechnology Consultation Agency Response Letter BNF No. 000045. http:/wayback. archive-it.org/7993/20171031093828/https:/www.fda. gov/Food/IngredientsPackagingLabeling/GEPlants/ Submissions/ucm161100.htm. Accessed 8 March 2018.

FDA, 1997c. Biotechnology Consultation Note to the File BNF No. 000042. FDA. http://wayback.archiveit.org/7993/20171031094445/https:/www.fda.gov/ Food/IngredientsPackagingLabeling/GEPlants/ Submissions/ucm161101.htm. Accessed 26 March. Accessed on 26 Mar 2018.

FDA, 1998. Biotechnology Consultation Agency Response Letter BNF No. 000054. http://wayback. archive-it.org/7993/20171031093146/https://www.fda. 
gov/Food/IngredientsPackagingLabeling/GEPlants/ Submissions/ucm161094.htm. Accessed 7 April 2018.

FDA, 1999a. Biotechnology Consultation Note to the File BNF No. 000060. http://wayback.archive-it. org/7993/20171031091240/https://www.fda.gov/ Food/IngredientsPackagingLabeling/GEPlants/ Submissions/ucm155791.htm. Accessed 8 March 2018.

FDA, 1999b. Biotechnology Consultation Agency Response Letter BNF No. 000060. http://wayback. archive-it.org/7993/20171031091310/https://www.fda. gov/Food/IngredientsPackagingLabeling/GEPlants/ Submissions/ucm155771.htm. Accessed 8 March 2018.

FDA, 2008. Biotechnology Consultation Note to the File BNF No. 000100. FDA. http://wayback.archiveit.org/7993/20171031090057/https://www.fda.gov/ Food/IngredientsPackagingLabeling/GEPlants/ Submissions/ucm155569.htm. Accessed 26 March 2018.

FDA, 2009. Biotechnology Consultation Agency Response Letter CFSAN/Office of Food Additive Safety. FDA, BNF No. 000101. http://wayback. archive-it.org/7993/20171031090404/https:/www.fda. gov/Food/IngredientsPackagingLabeling/GEPlants/ Submissions/ucm155564.htm. Accessed 26 March 2018.

FDA, 2015. Biotechnology Consultation Note to the File BNF No. 000132. FDA. http://wayback.archiveit.org/7993/20171031091552/https://www.fda.gov/ Food/IngredientsPackagingLabeling/GEPlants/ Submissions/ucm436168.htm. Accessed 26 March. 2018.

FDA, 2016. Biotechnology Consultation Agency Response Letter BNF No. 000149. FDA. https:// www.fda.gov/Food/IngredientsPackagingLabeling/ GEPlants/Submissions/ucm533372.htm. Accessed 24 September 2017.

Ferreira S.A., Pitz K.Y., Manshardt R., Zee F., Fitch M., Gonsalves, D., 2002. Virus coat protein transgenic papaya provides practical control of Papaya ringspot virus in Hawaii. Plant Dis. 86(2), 101-105.

FFP, 2017. U.S.: Arctic Apple set for commercial launch following successful trials. FreshFruitPortal.com, 22 May 2017. https://www.freshfruitportal.com/ news/2017/05/22/u-s-arctic-apple-set-commerciallaunch-following-successful-trials. Accessed 24 September 2017.

Fichtner F., Castellanos R., Ulker B., 2014. Precision genetic modifications: a new era in molecular biology and crop improvement. Planta 239(4), 921-939.

Firoozbady E., Young Th.R., 2015. Pineapple plant named 'rosé'. US plant patent PP25,763 P3, application by Del Monte Fresh Produce, filled 4.06.2012, published 4.08.2015. https:/www.lens.org/lens/ patent/197-779-624-196-993. Accessed 19 June 2018.
Fischoff D.A., Bowdish K.S., Perlak F.J., Marrone P.G., McCornick S.M., Niedermeyer J.G., ET AL., 1987 Insect tolerant transgenic tomato plants. Biotechnol. 5, 807-813.

Fitch M.M.M., Manshardt R.M., Gonsalves D., Slightom J.L., SANFORD J.C., 1992. Virus resistant papaya derived from tissues bombarded with the coat protein gene of Papaya ringspot virus. BioTechnol. 10, 1466-1472.

GAIN, 2011. Japan approved GM papaya. GAIN Rep. No. JA1048. https://gain.fas.usda.gov/Recent $\% 20$ GAIN\%20Publications/Japan \%20approved $\% 20$ GM\%20papaya_Tokyo_Japan_12-19-2011.pdf. Accessed 30 September 2017.

GAIN, 2014. Agricultural Biotechnology Annual. China. USDA Foreign Agricultural Service. GAIN Rep. No. 14032. https://gain.fas.usda.gov/ Recent\%20GAIN\%20Publications/Agricultural\%20 Biotechnology\%20Annual_Beijing_China\%20 -\%20Peoples\%20Republic\%20of_12-31-2014.pdf. Accessed 5 October 2017.

GAIN, 2016a. Agricultural Biotechnology Annual. Bangladesh. USDA Foreign Agricultural Service. GAIN Rep. No. BG6010. https:// gain.fas.usda.gov/Recent GAIN Publications/ Agricultural Biotechnology Annual_Dhaka Bangladesh_11-21-2016.pdf. Accessed 23 March 2018.

GAIN, 2016b. Agricultural Biotechnology Annual. Colombia remains open to new technologies. USDA Foreign Agricultural Service. GAIN Rep. 11/17/2016. https:/gain.fas.usda.gov/Recent GAIN Publications/ Agricultural Biotechnology Annual_Bogota Colombia_11-17-2016.pdf. Accessed 23 March 2018.

GAIN, 2016c. Agricultural Biotechnology Annual. Costa Rica, Ministry of agriculture supported biotech moratorium. USDA Foreign Agricultural Service. GAIN Rep. 12/20/2016. https://gain.fas.usda.gov/ Recent\%20GAIN\%20Publications/Agricultural\%20 Biotechnology\%20Annual_San\%20Jose_Costa\%20 Rica_12-20-2016.pdf. Accessed 23 March 2018.

GAIN, 2016d. Agricultural biotechnology annual: Japan. GAIN Rep. No. JA6050. https:/gain.fas. usda.gov/Recent\%20GAIN\%20Publications/ AGRICULTURAL\%20BIOTECHNOLOGY\%20 ANNUAL_Tokyo_Japan_11-30-2016.pdf. Accessed 30 September 2017.

Gocal, G., 2015. Non-transgenic trait development in crop plants using oligo-directed mutagenesis: Cibus' Rapid Trait Development System. In: NABC Report 26. New DNA-Editing Approaches: Methods, Applications and Policy for Agriculture. North American Agricultural Biotechnology Council, Ithaca, NY, 97-105.

Gonnet J-F, Fenet B., 2000. 'Cyclamen red' color based on a macrocyclic anthocyanin in carnation flowers. J. Agric. Food Chem. 48(1), 22-25.

Gonsalves D., 2004. Transgenic papaya in Hawaii and beyond. AgBioForum 71, 36-40. 
Gonsalves D., Gonsalves C., Ferreira S., Pitz K., Fitch M., Manshardt R., Slightom J., 2004. Transgenic virus-resistant papaya: from hope to reality in controlling Papaya ringspot virus in Hawaii. APSnet Features. http://www.apsnet.org/publications/ apsnetfeatures/Pages/PapayaRingspot.aspx. Accessed 30 September 2017.

GrEen J.M., 2009. Evolution of glyphosate-resistant crop technology. Weed Sci. 57(1), 108-117.

GriesbaCH R.J., 1993. Characterization of the flavonoids from Petunia $\times$ hybrida flowers expressing the A1 gene of Zea mays. HortScience, 28(6), 659-660.

GrIESBACH R.J., 2007. Petunia. In: Flower Breeding and Genetics. N.O. Anderson (ed.), Springer, Dordrecht, 301-336.

HC, 1995a. Suppressed polygalacturonase activity Flavr Savr ${ }^{\mathrm{TM}}$ tomato. Health Canada. https://www. canada.ca/en/health-canada/services/food-nutrition/ genetically-modified-foods-other-novel-foods/ approved-products/suppressed-polygalacturonaseactivity-flavr-savr-tomato.html. Accessed 2 March 2018.

HC, 1995b. Delayed ripening tomato line 1345-4. Health Canada. https:/www.canada.ca/en/health-canada/ services/food-nutrition/genetically-modified-foodsother-novel-foods/approved-products/delayedripening-tomato-line-1345-4.html. Accessed 5 March 2018.

HC, 1996. Suppressed polygalacturonase activity tomato hybrids, 1401F, H282F, 11013F, 7913F. Health Canada. https:/www.canada.ca/en/health-canada/ services/food-nutrition/genetically-modified-foodsother-novel-foods/approved-products/suppressedpolygalacturonase-activity-tomato-hybrids-1401fh282f-11013f-7913f.html. Accessed 30 March 2018.

HC, 1998a. Virus resistant squash line ZW-20. Health Canada. https:/www.canada.ca/en/health-canada/ services/food-nutrition/genetically-modified-foodsother-novel-foods/approved-products/virus-resistantsquash-line-20.html. Accessed 17 March 2018.

HC, 1998b. Virus resistant squash line CZW-3. Health Canada. https:/www.canada.ca/en/health-canada/ services/food-nutrition/genetically-modified-foodsother-novel-foods/approved-products/virus-resistantsquash-line-czw-3.html. Accessed 17 March 2018.

$\mathrm{HC}, 2000$. Insect (lepidopteran species) resistant tomato 5345. Health Canada. https://www.canada.ca/en/ health-canada/services/food-nutrition/geneticallymodified-foods-other-novel-foods/approved-products/ insect-lepidopteran-species-resistant-tomatoline-5345.html. Accessed 7 April 2018.

HC, 2003. Novel food information - Food biotechnology. Human food use of virus resistant papaya line 551. Health Canada. http://cera-gmc.org/files/cera/ GmCropDatabase/docs/decdocs/03-065-001.pdf. Accessed 30 September 2017.

HC, 2013. Determination of the safety of Cibus Canada Inc.'s canola (Brassica napus L.) event 5715. DD 2013-
100. Health Canada. http://inspection.gc.ca/plants/ plants-with-novel-traits/approved-under-review/ decision-documents/dd-2013-100/eng/142738333225 3/1427383674669. Accessed 5 April 2018.

HC, 2015. Novel food information - Arctic apple events GD743 and GS784. Health Canada. https:// www.canada.ca/en/health-canada/services/foodnutrition/genetically-modified-foods-other-novelfoods/approved-products/novel-food-informationarctic-apple-events-gd743-gs784.html. Accessed 24 September 2017.

HC, 2018. Novel food information - Arctic apple event NF872. Health Canada. https:/www.canada.ca/en/ health-canada/services/food-nutrition/geneticallymodified-foods-other-novel-foods/approved-products/ arctic-fuji-apple/information.html. Accessed 5 April 2018.

Hobson G.E., 1965. The firmness of tomato fruit in relation to polygalacturonase activity. J. Hort. Sci. 40, 66-72.

Holton T.A., 1996. Transgenic plants exhibiting altered flower color and methods for producing same. International Patent WO/1996/036716, applied by International Flower Developments Pty. Ltd., filled 16.05.1996, published 21.11.1996. https://patentscope. wipo.int/search/en/detail.jsf?docId=WO1996036716. Accessed 19 June 2018.

IATP, 2001. GM food crops and application of substantial equivalence in the European Union. https://www.iatp. org/files/GM_Food_Crops_and_Application_of Substantial_E.htm. Accessed 7 April 2018.

ICA, 2000. Por la cual se autoriza la introducción de plantas de clavel modificado genéticamente. Resolucion No. 1219 (18 MAY 2000). http://bch. cbd.int/database/attachment/?id=14170. Accessed 18 January 2018.

ICA, 2008. Por la cual se autoriza la importación del material reproductivo de claveles modificados por las técnicas de ingeniería genética para producción de flor cortada para exportación. Resolucion No. 3932 (20 NOVEMBER 2008). https://www.ica. gov.co/getattachment/978557f9-da42-4f80-85f6947b27f67a25/2008R3932.aspx. Accessed 18 January 2018.

ICA, 2009. Resolución 3786: Por la cual se autoriza adelantar siembra experimental en invernadero de Rosas Modificadas. Genéticamente para el color de la flor mediante el Vector binario pSPB130 para produccion de flor cortada para exportacion. https:// www.ica.gov.co/getattachment/37101b43-3129-4008b448-2bda8e762027/3857.aspx. Accessed 18 January 2018.

ICA, 2012. Resolución 3570: Por la cual se autoriza la importación del material reproductivo de Crisantemo de flor azul, modificados con los vectores de Transformación pCGP3618, pCGP3633 y pCGP3641, para producción de flor cortada para exportación. https://www.ica.gov.co/getattachment/37101b43- 
3129-4008-b448-2bda8e762027/3857.aspx. Accessed 18 January 2018.

ILSI, 2011. A review of the environmental safety of the CrylAc protein. International Life Sciences Institute Research Foundation. Environ. Biosafety Res. 10, $27-$ 49.

ISAAA, 2009. Pocket K No. 35: Bt brinjal in India. http:/ isaaa.org/resources/publications/pocketk/35/default. asp. Accessed 4 March 2018.

ISAAA, 2015. Brief 51: Executive Summary. http:// Www.isaaa.org/resources/publications/briefs/51/ executivesummary/default.asp. Accessed 4 March 2018.

ISAAA, 2016a. Global status of commercialized biotech/ GM crops: 2016. ISAAA Brief 52, ISAAA, Ithaca, New York, USA.

ISAAA, 2016b. Pocket K. No. 48: Bt eggplant. http:// www.isaaa.org/resources/publications/pocketk/48/ default.asp. Accessed 4 March 2018.

ISAAA, 2017. ISAAA donor support group. http:// Www.isaaa.org/inbrief/donors/default.asp. Accessed 4 October 2017.

JAMES C., 2014. Global status of commercialized biotech/ GM crops: 2014. ISAAA Brief 49, ISAAA, Ithaca, New York, USA.

JCH, 2004a. Purple-violet carnation 123.8.8 ( F3'5'H, DFR, Dianthus caryophyllus L.) (OECD UI: FLO40685-1). Japan Clearing House. http://www.biodic. go.jp/bch/download/en_lmo/FLO40685enRi.pdf. Accessed 18 December 2017.

JCH, 2004b. Purple-violet carnation 123.2.38 (F3'5'H, DFR, Dianthus caryophyllus L.) (OECD UI: FLO40644-4) Japan Clearing House. http://www.biodic. go.jp/bch/download/en_lmo/FLO40644enRi.pdf. Accessed 18 December 2017.

JCH, 2004c. Purple-violet carnation 11363 (F3'5'H, DFR, Dianthus caryophyllus L.) (OECD UI: FLO-11363-1). Japan Clearing House. http://www.biodic.go.jp/bch/ download/en_lmo/FLO11363enRi.pdf. Accessed 18 December 2017.

JCH, 2004d. Purple-violet carnation 11 (F3'5'H, DFR, Dianthus caryophyllus L.) (OECD UI: FLO-07442-4). Japan Clearing House. http://www.biodic.go.jp/bch/ download/en_lmo/FLO07442enRi.pdf. Accessed 18 December 2017.

JCH, 2008a. Rose Variety with modified flavonoid biosynthesis pathway (F3'5'H, 5AT, Rosa hybrida) (WKS82/130-4-1, ECD UI: IFD-52401-4). Japan Clearing House. http:/Www.biodic.go.jp/bch/ download/en_lmo/130_4_1_2008enRi.pdf. Accessed 18 December 2017.

JCH, 2008b. Rose Variety with modified flavonoid biosynthesis pathway (F3'5'H, 5AT, Rosa hybrida) (WKS82/130-9-1, OECD UI: IFD-52901-9). Japan Clearing House. http://www.biodic.go.jp/bch/ download/en_lmo/130_9_1_2008enRi.pdf. Accessed 18 December 2017.
JCH, 2009. Purple-violet carnation ( F3'5'H, DFR, sur B, Dianthus caryophyllus L.) (123.8.12, OECD UI: FLO-40689-6). Japan Clearing House. http://www. biodic.go.jp/bch/download/en_lmo/FLO40689enRi. pdf. Accessed 18 December 2017.

JRC EU, 2007. Report on the testing of a PCR-based detection method for identification of Florigene ${ }^{\mathrm{TM}}$ Moonlite GM carnation. Protocol Version 2. http:// gmoinfo.jrc.ec.europa.eu/docs/C-NL-04-02\%20 CRL\%20method.pdf. Accessed on 24 April 2018.

Kato K., Yoshida R., Kikuzaki A., Hirai T., Kuroda H., Hiwasa-Tanase K., et AL., 2010. Molecular breeding of tomato lines for mass production of miraculin in a plant factory. J. Agric. Food Chem. 58, 9505-9510.

Katsumoto Y., Fukuchi-Mizutani M., Fukui Y., Brugliera F., Holton T.A., Karan M., et Al., 2007. Engineering of the rose flavonoid biosynthetic pathway successfully generated blue-hued flowers accumulating delphinidin. Plant Cell Physiol. 48(11), 1589-1600.

Keeler S.J., Sanders P., Smith J.K., Mazur B.J., 1993. Regulation of tobacco acetolactate synthase gene expression. Plant Physiol. 102(3), 1009-1018.

Kitagawa M., Nakamura K., Kondo K., Ubukata S., Akiyama H., 2014. Examination of processed vegetable foods for the presence of common DNA sequences of genetically modified tomatoes. J. Food Hyg. Saf. Sci. 55(5), 247-253.

Kyodo, 2011. Suntory to sell blue roses overseas. The Japan Times 16 September 2011. https://www. japantimes.co.jp/news/2011/09/16/news/suntory-tosell-blue-roses-overseas. Accessed 22 April 2018.

LisA V., LeCOQ H., 1984. Zucchini yellow mosaic virus. CMI/AAB Descriptions of plant viruses, no. 282.

Lu C., Chandler S.F., Mason J.G., Brugliera F., 2003. Florigene flowers: from laboratory to market. In: Plant Biotechnology 2002 and Beyond. I.K. Vasil (ed.), Springer, Dordrecht, 333-336.

Luis-Arteaga M., Alvarez J.M., Alonso-Prados J.L., Bernal J.J., García-Arenal F., Lavina A., et Al., 1998. Occurrence, distribution, and relative incidence of mosaic viruses infecting field-grown melon in Spain. Plant Dis. 82, 979-982.

Mallah N., Obeid M., Sleymane G.A., 2017. Comprehensive matrices for regulatory approvals and genetic characterization of genetically modified organisms. Food Control 80, 52-58.

Meyer P., Heidmann I., 1994. Epigenetic variants of a transgenic petunia line show hypermethylation in transgene DNA: an indication for specific recognition of foreign DNA in transgenic plants. Mol. Gen. Genet. 243(4), 390-399.

Meyer P., Heidmann I., Forkmann G., Saedler H., 1987. A new petunia flower colour generated by transformation of a mutant with a maize gene. Nature 330(6149), 677-678. 
Meyer P., Heidmann I., Saedler H., Forkmann G., 1995. Plants with modified flower color and methods for their production by genetic engineering. US patent $5,410,096$, application by the inventors, filled 28.08.1990, published 25.04.1995. https://patentscope. wipo.int/search/en/detail.jsf?docId=US38462462. Accessed 19 June 2018.

MOEF, 2010. Decision on commercialisation of Btbrinjal. http://www.moef.nic.in/downloads/publicinformation/minister_REPORT.pdf. Accessed 28 March 2018.

NAKAmURA N., 2010. Dream comes true: development of a blue rose 'Applause' and its fragrance. J. Jpn. Assoc. Odor. Environ. 41(3), 150-156.

Nakamura N., Fukuchi-Mizutani M., Katsumoto Y., Togami J., Senior M., Matsuda Y., et AL., 2011. Environmental risk assessment and field performance of rose (Rosa $\times$ hybrida) genetically modified for delphinidin production. Plant Biotechnol. 28(2), 251261.

NaKayama T., SuzuKi H., Nishino T., 2003. Anthocyanin acyltransferases: specificities, mechanism, phylogenetics, and applications. J. Mol. Catalysis B: Enzymatic, 23(2-6), 117-132.

Nap J.P., Metz P.L., Escaler M., Conner A.J., 2003. The release of genetically modified crops into the environment. Part I. Overview of current status and regulations. Plant J. 33(1), 1-18.

NBB, 2012. Application for approval for commercial import of cut flowers of novel flower colour varieties of genetically modified carnation (Dianthus caryophyllus L.). The National Biosafety Board REF. NO: JBK(S) 602-1/1/8. http://www.biosafety.nre.gov. my/country_decision/product_lmo/jbk(s)\%206021-1-8/Decision\%20Statement $\% 20$ of $\% 20$ GM $\% 20$ Carnation.pdf. Accessed 18 January 2018.

Noda N., Aida R., Kishimoto S., Ishiguro K., FukUchiMizutani M., Tanaka Y., OhmiYa A., 2013. Genetic engineering of novel bluer-colored chrysanthemums produced by accumulation of delphinidin-based anthocyanins. Plant Cell Physiol. 54(10), 1684-1695.

Noda N., TanaKa Y., 2013. Violet-blue chrysanthemums. Oxford University Press's Blog 21 November 2013. https://blog.oup.com/2013/11/violet-bluechrysanthemum-genetic-modification. Accessed 21 January 2018.

Noda N., Yoshioka S., Kishimoto S., Nakayama M., Douzono M., Tanaka Y., Aida R., 2017. Generation of blue chrysanthemums by anthocyanin B-ring hydroxylation and glucosylation and its coloration mechanism. Sci. Adv. 3(7), e1602785.

OECD, 2002.Guidance for the designation of a unique identifier for transgenic plants. OECD. http://www. oecd.org/officialdocuments/displaydocument/?docl anguage $=$ en $\& \operatorname{cote}=$ env $/ \mathrm{jm} / \mathrm{mono}(2002) 7$. Accessed 3 October 2017.

OGTR, 2003a. Commercial release of colour modified carnation - replacement of deemed licence GR-
2. Licence No.: DIR 030/2002. http://ogtr.gov.au/ internet/ogtr/publishing.nsf/Content/dir030-3/\$FILE/ dir030lic.pdf Accessed on 18 January 2018.

OGTR, 2003b. Risk assessment and risk management plan. Commercial release of colour modified carnation - replacement of deemed licence GR-2. DIR 030/2002. http://content.webarchive.nla.gov.au/gov/ wayback/20130904044522/http://www.ogtr.gov.au/ internet/ogtr/publishing.nsf/Content/dir030-3/\$FILE/ dir030finalrarmp.pdf. Accessed 22 April 2018.

OGTR, 2007. Notification that dealings with genetically modified carnation lines have been included on the GMO register. http:/www.ogtr.gov.au/internet/ogtr/ publishing.nsf/Content/reg001det1-htm. Accessed 22 April 2018.

OGTR, 2009. Licence for dealings involving an intentional release of a GMO into the environment: Commercial release of rose genetically modified for altered flower colour. Licence No. DIR 090. http:// ogtr.gov.au/internet/ogtr/publishing.nsf/Content/ dir090-3/\$FILE/dir090lic.pdf. Accessed 18 January 2018.

OGTR, 2015a. Commercial import and distribution of GM carnation cut-flowers with altered flower colour. Licence No.: DIR 134. http://www.ogtr.gov.au/ internet/ogtr/publishing.nsf/Content/dir134/\$FILE/ Licence $\% 20$ conditions.pdf. Accessed 18 January 2018.

OGTR, 2015b. Risk assessment and risk management plan for DIR 134. Commercial import and distribution of GM carnation cut-flowers with altered flower colour. http://www.ogtr.gov.au/internet/ogtr/publishing. nsf/Content/dir134/\$FILE/Ful1\%20Risk\%20 Assessment $\% 20$ and $\% 20$ Risk $\% 20$ Management $\% 20$ Plan.pdf. Accessed 18 January 2018.

OGTR, 2017. Licence for dealings involving an intentional release of a GMO into the environment. Licence No.: DIR 109. http://www.ogtr.gov.au/internet/ogtr/ publishing.nsf/Content/76F9A6576471A5D0CA25 7CD1000D2AB3/\$File/Licence\%20Conditions.pdf. Accessed 9 April 2018.

PFSEH, 2017. Labelling system for genetically modified food and proposed introduction of pre-market safety assessment scheme. Hong Kong Legislative Council paper No. CB(2)1809/16-17(01). https://www. legco.gov.hk/yr16-17/english/panels/fseh/papers/ fseh20170711cb2-1809-1-e.pdf. Accessed 23 March 2018.

Polak J., Kundu J.K., Krska B., Beoni E., Kominek P., Pivalova J., Jarosova J., 2017. Transgenic plum Prunus domestica L., clone C5 (cv. HoneySweet) for protection against sharka disease. J. Integr. Agric. 16(3), 516-522.

Puette L., 2016. The splice must grow: The bright and shady sides of GM agriculture in China. Market Reports 6. http://www.chinaag.org/markets/gmagriculture-in-china. Accessed 30 September 2017. 
Raghavan V., Malik P.S., Choudhury N.R., MukherJeE S.K., 2004. The DNA-A Component of a plant geminivirus (Indian Mung Bean Yellow Mosaic Virus) replicates in budding yeast cells. J. Virology 78(5), 2405-2413.

RAPPLER, 2016. SC reverses earlier roling on Bt talong, GMOs. https://www.rappler.com/science-nature/ environment/141043-sc-reverses-ruling-bt-talonggmo. Accessed 8 April 2018.

Reed A.J. Magin K.M., Anderson J.S., Austin G.D., Rangwala T., Linde D.C., ET AL., 1995. Delayed ripening tomato plants expressing the enzyme 1-aminocyclopropane-1-carboxylic acid deaminase. 1. Molecular characterization, enzyme expression, and fruit ripening traits. J. Agric. Food Chem. 43(7), 1954-1962.

Rimbaud L., Dallot S., Gottwald T., Decrooce V., Jacquot E., Soubeyrand S., Thébaud G., 2015. Sharka epidemiology and worldwide management strategies: learning lessons to optimize disease control in perennial plants. Ann. Rev. Phytopathol. 53(1), 357-378.

Savin K.W., Baudinette S.C., Graham M.W., Michael M.Z., Nugent G.D., Lu C.Y., Cornish, E.C., 1995. Antisense ACC oxidase RNA delays carnation petal senescence. HortScience, 30(5), 970-972.

SchuttelaAR, 2015. The regulatory status of New Breeding Techniques in countries outside the European Union. Schuttelaar \& Partners. Version: June 2015. http://www.nbtplatform.org/backgrounddocuments/rep-regulatory-status-of-nbts-oustide-theeu-june-2015.pdf. Accessed 4 April 2018.

ScorzA R., 2006. Application for determination of non-regulatory status for C5 ('HoneySweet') plum (Prunus domestica L.) resistant to Plum pox virus. Identifier: ARS-PLMC5-6. http://cera-gmc.org/docs/ decdocs/07-313-003.pdf. Accessed 25 March 2018.

Scorza R., Callahan A., Dardick Ch., Ravelonandro M., Polak J., Malinowski T., et Al., 2013. Genetic engineering of Plum pox virus resistance: 'HoneySweet' plum - from concept to product. Plant Cell Tiss. Org. Cult. 115(1), 1-12.

Scorza R., Ravelonandro M., Gonsalves D., 2004. Plum tree named 'honeysweet'. US plant patent PP15,154 P2, application by US Institut National de la Recherche Agronomique and Cornell Research Foundation, Inc., filled 31.08.2001, published 21.09.2004. https://www.lens.org/lens/ patent/076-366-849-381-273. Accessed 19 June 2018.

Scorza R., Ravelonandro M., Callahan A., Zagrai I., Polak J., Malinowski T., et al., 2016. 'HoneySweet' (C5), the first genetically engineered Plum pox virus-resistant plum (Prunus domestica L.) cultivar. HortScience 51(5), 601-603.

SEARCA, 2017. Bangladesh to release 3 more Bt brinjal varieties. http://bic.searca.org/site/bangladesh-torelease-3-more-bt-brinjal-varieties/. Accessed 8 April 2018.
SERVICK K., 2017a. How the transgenic petunia carnage of 2017. American Association for the Advancement of Science, Science news, Engineering Plants \& Animals Science and Policy May 24, 2017. http:/ www.sciencemag.org/news/2017/05/how-transgenicpetunia-carnage-2017-began. Accessed 1 February 2018.

SERVICK K., 2017b. The strange case of the orange petunias. Science 356(6340), 792.

SidDiQue A., 2017. Bangladesh to provide incentives for farmers to grow more GMO Bt eggplant. https:// geneticliteracyproject.org/2017/10/24/bangladeshto-provide-incentives-farmers-grow-more-gmo-bteggplant/\#.WfBXtio81sc.twitter. Accessed 28 March 2018.

Smart R.D., Blum M., Wesseler J., 2017. Trends in approval times for genetically engineered crops in the United States and the European Union. J. Agric. Econ. 68(1), 182-198.

Songstad D., Petolino J., Voytas D., Reichert N., 2017. Genome editing of plants. Critical Rev. Plant Sci. 36(1), 1-23.

SpARKs B., 2018. Suntory blue rose 'Applause' takes center stage on Grammy's Red Carpet. Greenhouse Grower 27 February 2018. http://www.greenhousegrower. $\mathrm{com} /$ varieties/suntory-blue-rose-applause-takescenter-stage-on-grammys-red-carpet. Accessed 23 April 2018.

Sprink T., Eriksson D., Schiemann J., Hartung F., 2016. Regulatory hurdles for genome editing: processvs. product-based approaches in different regulatory contexts. Plant Cell Rep. 35(7), 1493-1506.

Svitashev S., Schwartz C., Lenderts B., Young J., Cigan A., 2016. Genome editing in maize directed by CRISPR-Cas9 ribonucleoprotein complexes. Nat. Commun. 7, 13274.

Tanaka Y., Brugliera F., 2013. Flower colour and cytochromes P450. Phil. Trans. R. Soc. B 368, 20120432.

Tanaka Y., Brugliera F., Chandler S., 2009. Recent progress of flower colour modification by biotechnology. Intl. J. Mol. Sci. 10(12), 5350-5369.

TANaka Y., Sasaki N., OhmiYa A,. 2008. Biosynthesis of plant pigments: anthocyanins, betalains and carotenoids. Plant J. 54(4), 733-749.

Tennant P.F., Gonsalves C., Ling K.-S., Fitch M., Manshardt R., Slightorn J.L., Gonsalves D., 1994. Differential protection against Papaya ringspot virus isolates in coat protein gene transgenic papaya and classically cross-protected papaya. Phytopathology 84, 1359-1366.

Tricoli D.M., Carney K.J., Russell P.F., Quemada H.D., McMaster R.J., Reynolds J.F., Deng R.Z., 2002. Transgenic plants expressing DNA constructs containing a plurality of genes to impart virus resistance. US patent 6337431, applied by Seminis Vegetable Seeds, Inc., filled 6.10.1997, published 
8.01.2002. https://patentscope.wipo.int/search/en/ detail.jsf?docId=US39710896. Accessed 19 June 2018.

USDA, 2015a. Report on genetically engineered plant imports: Current and future. USDA, FY2015. https:// Www.aphis.usda.gov/biotechnology/downloads/ audits/fy15_ge_plant_imports_rpt.pdf. Accessed 4 October 2017.

USDA, 2015b. Coexistence fact sheets: Specialty farming. USDA Factsheet, February 2015. https:// www.usda.gov/sites/default/files/documents/ coexistence-specialty-farming-factsheet.pdf. Accessed 30 September 2017.

USDA, 2016. National Nutrient Database for Standard Reference Release 28. USDA-ARS. https://ndb.nal. usda.gov/ndb/search/list?qlookup=09003. Accessed 24 September 2017.

USDA Press, 2018. Secretary Perdue issues USDA statement on plant breeding innovation. USDA Office of Communications. Press Release No. 0070.18 of 28 March 2018.

VelleKoop E., 2015. Genetic modification accepted in floriculture. Floral Daily 28 September 2015. http://www.floraldaily.com/article/2105/Geneticmodification-accepted-in-floriculture. Accessed 20 April 2018.

Vellekoop E., 2017. Blue roses do not come out of the blue. Floral Daily 13 October 2017. http://www. floraldaily.com/article/12179/Blue-roses-do-notcome-out-of-the-blue. Accessed 23 April 2018.

Wawrzyniak A., MarciniaK A., Rajewska J., 2005. Lycopene content of selected foods available on the
Polish market and estimation of its intake. Pol. J. Food Nutr. Sci. 14/55(2), 195-200.

Wolt J., WANG K., YANG B., 2016. The regulatory status of genome-edited crops. Plant Biotechnol. J. 14(2), $510-518$.

Wong A.Y.-T., Chan A.W.-K., 2016. Genetically modified foods in China and the United States: A primer of regulation and intellectual property protection. Food Sci. Human Wellness 5, 124-140.

WTO, 2008. EC approval and marketing of biotech products. Dispute Settlement Reports 2006, Volume IV: Pages 1249 to 1754, Cambridge University Press, 1529.

Yeh S.-D., Bau H.-J., Cheng Y.-H., Fan Ch.-Ch., KUnG Y.-J., CHEN S., ET AL., 2011. Isolated nucleic acid molecules from transgenic papaya line 16-0-1 resistant to papaya ringspot virus and use thereof. US patent $8,258,282$ B2, application by National Chung Hsing University, filled 23.12.2009, published 28.04.2011. https://patentscope.wipo.int/search/en/ detail.jsf?docId=US73224496. Accessed 19 June 2018.

Yokotani N., Nakano R., Imanishi S., Nagata M., InAba A., Kubo Y., 2009. Ripeningassociated ethylene biosynthesis in tomato fruit is autocatalytically and developmentally regulated. J. Exp. Bot. 60(12), 3433-3442.

Yoruk R., Marshall M.R., 2003. Physicochemical properties and function of plant polyphenol oxidase: A review. J. Food Biochem. 27, 361-422.

Received April 28, 2018; accepted June 21, 2018 